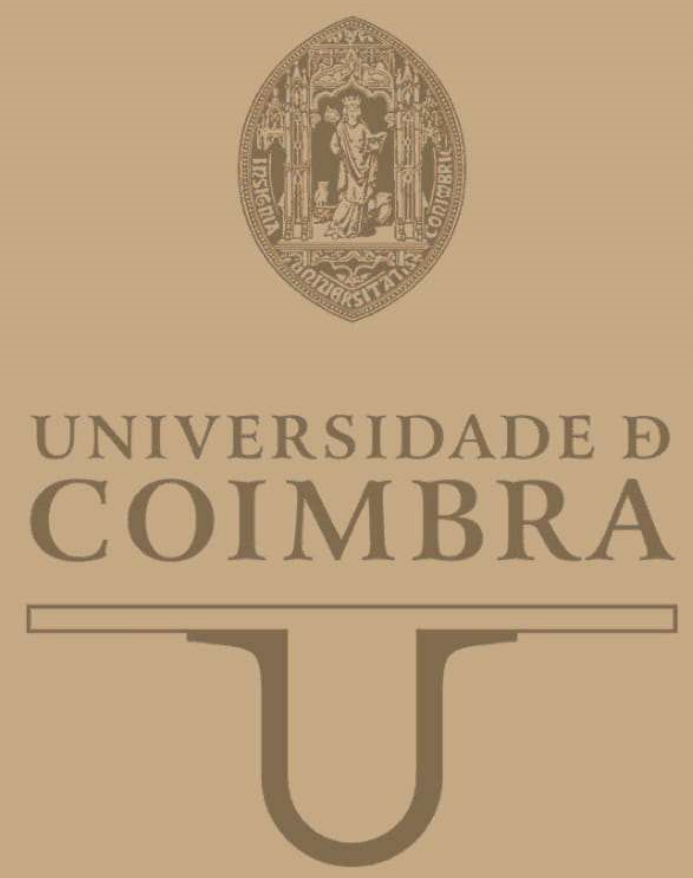

Rodrigo Forte

\title{
O DISCURSO DO DUMPING SOCIAL NO SISTEMA COMERCIAL INTERNACIONAL
}

\begin{abstract}
VOLUME 1
Dissertação no âmbito do Mestrado em Direito, na Área de Especialização de Ciências JurídicoEconómicas, orientada pelo Professor Doutor Luís Pedro Cunha e apresentada à Faculdade de Direito da Universidade de Coimbra.
\end{abstract}

Maio de 2019 
FACULDADE DE DIREITO

UNIVERSIDADE O

COIMBRA

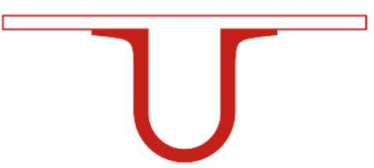

RODRIGO SALIM MELO CAVALCANTE FORTE

\section{O DISCURSO DO DUMPING SOCIAL NO SISTEMA COMERCIAL INTERNACIONAL}

THE SPEECH OF SOCIAL DUMPING IN THE INTERNATIONAL COMMERCIAL SYSTEM

Dissertação apresentada à Faculdade de Direito da Universidade de Coimbra no âmbito do 2. ${ }^{\circ}$ Ciclo de Estudos em Direito (conducente ao grau de Mestre), na Área de Especialização em Ciências JurídicoEconómicas.

Orientador: Professor Doutor Luís Pedro Cunha. 


\title{
RO RODRIGO SALIM MELO CAVALCANTE FORTE
}

\section{O DISCURSO DO DUMPING SOCIAL NO SISTEMA COMERCIAL INTERNACIONAL}

\begin{abstract}
Dissertação apresentada à Faculdade de Direito da Universidade de Coimbra no âmbito do 2. ${ }^{\circ}$ Ciclo de Estudos em Direito (conducente ao grau de Mestre), na Área de Especialização em Ciências JurídicoEconómicas.
\end{abstract}

APRESENTADA EM:

l l

BANCA EXAMINADORA

Senhor Professor Doutor Luís Pedro Cunha

Faculdade de Direito da Universidade de Coimbra

Examinador 2

Instituição

Examinador 3

Instituição 


\section{RESUMO}

A presente investigação tem por tema o discurso do dumping social no sistema comercial internacional. Nela analisa-se a ocorrência transversal de uma retórica simplista, maniqueísta e essencialmente polarizadora no âmbito do sistema comercial internacional, mais especificamente sobre duas ocorrências marcadamente ressonantes: a polêmica da cláusula social no âmbito do "subsistema multilateral" e a controvérsia do destacamento temporário de trabalhadores no seio do "subsistema regional", notadamente no contexto de expansão/integração da União Europeia.

Desta forma, o presente texto não tem por objeto o dumping social em si, seja enquanto fenômeno jurídico-econômico autônomo, seja na condição de derivação do gênero dumping (comercial). Assim, o estudo parte de rápida revisão propedêutica das teorias do comércio internacional e do histórico do multilateralismo e das organizações multilaterais de comércio, apresenta a evolução da ideia de dumping desde os primórdios com Jacob Viner até atingir a qualidade de fenômeno jurídico-econômico bem delimitado, mas que, ao ser integrado ao GATT e instrumentalizado no âmbito da defesa comercial via direitos antidumping, acabou por ser utilizado como instrumento de políticas neoprotecionistas ou desenvolvimentistas que põem em rota de colisão os interesses comerciais dos países desenvolvidos com os dos países em desenvolvimento, no seio da OMC.

$\mathrm{Na}$ sequência, o estudo recai sobre o discurso, a retórica ou a acusação, do dumping social enquanto estratagema narrativo comumente empregado por populistas tanto para antagonizar os interesses de países desenvolvidos aos dos países em desenvolvimento tanto no âmbito do comércio multilateral, quanto na da promoção da oposição norte do sul e leste do oeste na União Europeia. Em seguida, é apresentada a ideia de marquetização como exemplo de abordagem mais racional, e não polarizadora, que pode ajudar a esclarecer os processos grosseiramente abordados pela retórica do dumping social. $\mathrm{O}$ arremate fica por conta da reafirmação da importância do discurso do dumping social ante à ausência de delimitação ou conceptualização do dumping social enquanto derivado do dumping comercial.

Palavras-chave: Discurso polarizador. Dumping social. Cláusula social. Destacamento de trabalhadores. Marquetização. 


\begin{abstract}
This investigation analyses the social dumping discourse in the international trading system. It studies the cross-cutting occurrence of a simplistic, Manichean and essentially polarizing rhetoric within the international trading system, specifically son two highly polarizing occurrences: the controversy over social clause within the "multilateral subsystem" and the posted workers controversy in the "regional subsystem", specifically in the context of the European Union expansion.

Therefore, the subject of this text is not the social dumping itself, no as an autonomous phenomenon neither as a derivation of the dumping (commercial). So, the study starts from a fast review of the basic's theories about international trade and the history of multilateralism and multilateral trade organizations. It goes on to present the evolution of the idea of dumping from the earliest ideas with Jacob Viner until it reaches the status of a well-defined legal-economic phenomenon, but which, when integrated with the GATT, as instrumental in the commercial defense as the anti-dumping duties, was eventually used as trade protectionism tools or development policy instruments that put the free trade interests of the developed country against to the developing in the WTO.

Next, this work try to understand the discourse, the rhetoric, or the accusation, of social dumping as a narrative subterfuge commonly employed by populists to antagonize the interests of developed countries with those of developing countries in both multilateral trade and promotion of the opposition North of the South and East of the West in the European Union. Next, the idea of marketization is offered as an example of a more lucid approach that can help to clarify the processes grossly addressed by the rhetoric of social dumping. The ending is about the endorsement of the importance of the social dumping as a discourse, once that the demarcation attempts or conceptualization of social dumping as derived from dumping has been failed.
\end{abstract}

Keywords: Polarizing discourse. Social dumping. Social clause. Posting of workers. Marketization. 


\section{LISTA DE SIGLAS E ABREVIATURAS}

\begin{tabular}{|c|c|}
\hline AARU & Acordo Antidumping da Rodada do Uruguai \\
\hline ASMC & Acordo sobre Subsídios e Medidas Compensatórias \\
\hline ASS & Acordo sobre Salvaguardas \\
\hline BIRD & $\begin{array}{l}\text { Banco Internacional para a Reconstrução e Desenvolvimento ou } \\
\text { Banco Mundial }\end{array}$ \\
\hline EM & Estado-membro \\
\hline EUA & Estados Unidos da América \\
\hline FMI & Fundo Monetário Internacional \\
\hline GATT & $\begin{array}{l}\text { General Agreement on Tariffs and Trade (Acordo Geral sobre Tarifas } \\
\text { e Comércio) }\end{array}$ \\
\hline MERCOSUL & Mercado Comum do Sul \\
\hline NAALC & North American Agreement on Labour Cooperation \\
\hline NAFTA & North American Free Trade Association \\
\hline NIP & Novos Países Industrializados ("Tigres Asiáticos") \\
\hline OIC & Organização Internacional do Comércio \\
\hline OIT & Organização Internacional do Trabalho \\
\hline OMC & Organização Mundial do Comércio \\
\hline ONG & Organização não Governamental \\
\hline ORC & Órgão de Resolução de Conflitos \\
\hline PAD & Países Atualmente Desenvolvidos \\
\hline PED & Países em Desenvolvimento \\
\hline PIB & Produto Interno Bruto \\
\hline PPO & Princípio do País de Origem \\
\hline TI & Tecnologia da Informação \\
\hline TJUE & Tribunal de Justiça da União Europeia \\
\hline $\mathbf{U E}$ & União Europeia \\
\hline USMCA & United States-Mexico-Canada Agreement \\
\hline
\end{tabular}




\section{SUMÁRIO}

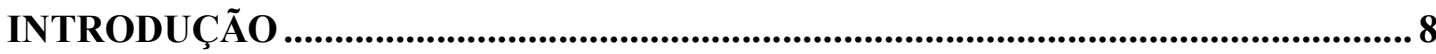

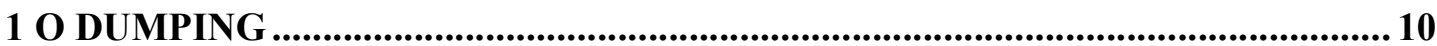

$1.1 \mathrm{O}$ comércio internacional ..................................................................................... 10

1.2 O Sistema Comercial Internacional .................................................................. 13

1.2.1 O multilateralismo ......................................................................................... 14

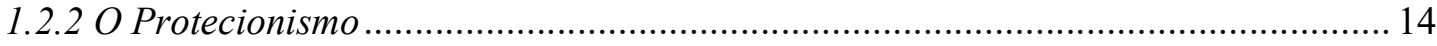

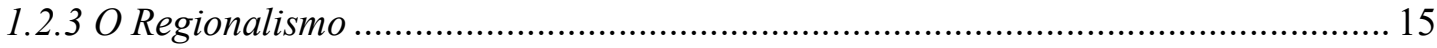

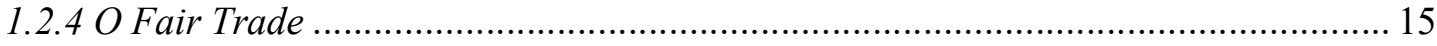

1.3 Defesa comercial e dumping........................................................................................... 15

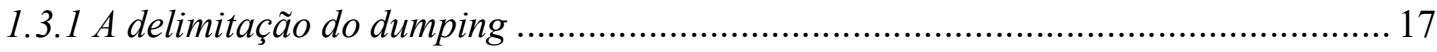

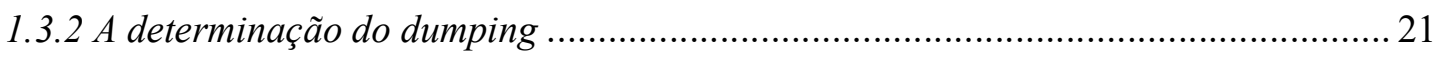

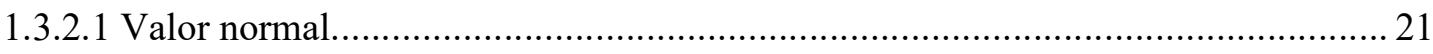

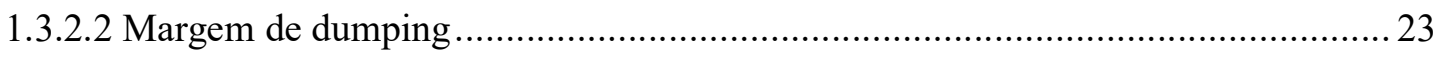

1.3.2.3 Configuração do dano e nexo causal ................................................................. 24

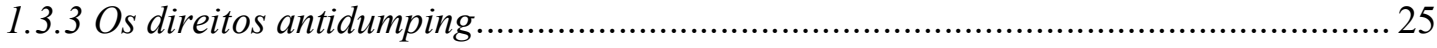

1.3.3.1 Direitos antidumping, direito antitruste e a lógica liberal..................................... 26

1.3.3.2 Interesse público na aplicação dos direitos antidumping........................................ 29

1.4 Dumping e os direitos antidumping como instrumento de política comercial ou

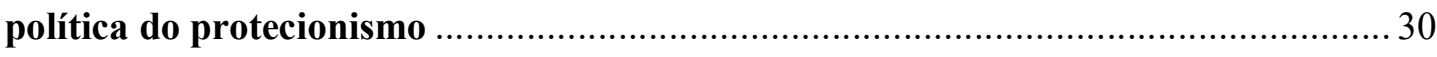

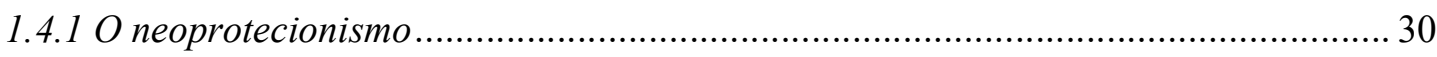

1.4.2 As medidas antidumping como estratégia desenvolvimentista ................................... 33

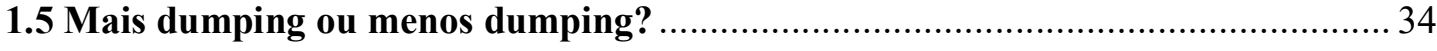

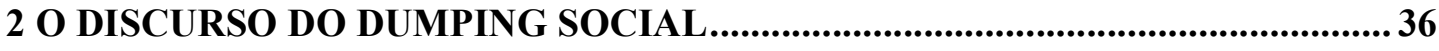

2.1 Sobre discursos polarizadores..................................................................................36

2.2 O discurso do dumping social no subsistema multilateral de comércio ………..... 38

2.2.1 A legitima demanda por trabalho digno na economia global ................................... 38

2.2.2 Globalização, desenvolvimento econômico e interdependência .................................. 43

2.2.3 O discurso do dumping social: neoprotecionismo e polarização entre PAD e PED. 47

2.2.3.1 A legítima demanda por desenvolvimento............................................................. 51 
2.2.4 Da pragmática normatização do dumping no comércio internacional à polêmica da

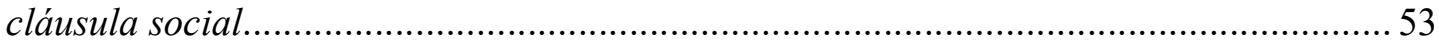

2.2.4.1 A cláusula social e o risco de "deslegalização" da OMC …................................... 56

2.2.4.2 Soluções viáveis para elevação das condições sociolaborais no multilateralismo.. 58

2.3 O discurso do dumping social no subsistema regional de comércio internacional 60

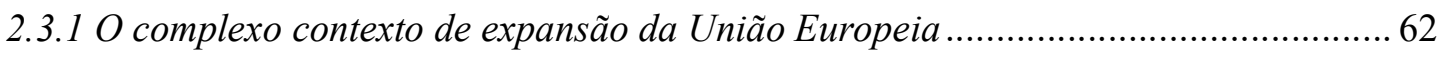

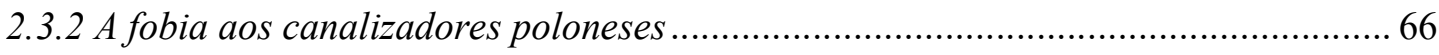

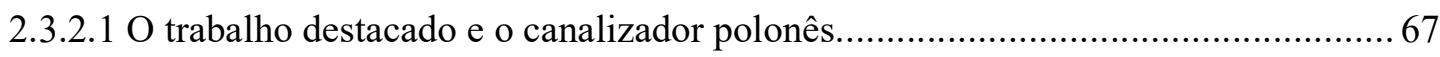

2.3.2.2.1 Caso Rush Portuguesa: Processo c-113/89, acórdão dia 27 de março de 1990 ... 73

2.3.2.2.2 Caso Portugália: Processo C-164/99, acórdão de 24 de janeiro de 2002 ….......... 74

2.3.2.2.3 Caso Laval: Processo C-341/05, acórdão de 18 de dezembro de 2007 .............. 75

2.3.2.2.4 Caso Elektrobudowa: Processo C-396/13, acórdão de 12 de fevereiro de 2015.76

2.3.2.3 O destacamento de trabalhadores na Europa e o discurso do dumping social........ 78

2.4 Sobre discursos polarizadores a partir de uma ideia de dumping social................ 80

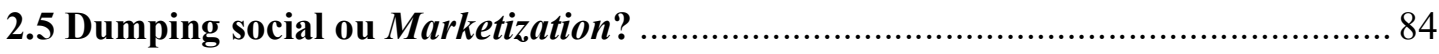

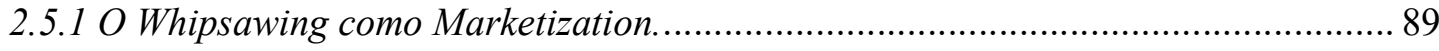

2.5.2 Marketization e a liberalização do mercado de trabalho na União Europeia .......... 92

3 DO DISCURSO DO DUMPING SOCIAL AO DUMPING SOCIAL? .................... 93

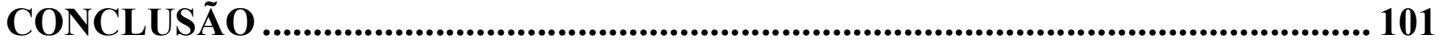

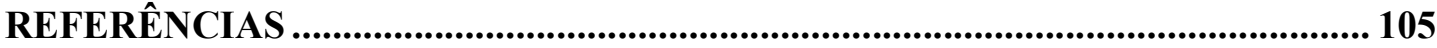




\section{INTRODUÇÃO}

O presente texto não tem por objeto o dumping (comercial), nem se dispõe a oferecer uma delimitação ou conceituação do dumping social em si. Na realidade, procura analisar o discurso do dumping social enquanto retórica assaz polarizadora que põe em rota de colisão os interesses de países desenvolvidos com os dos países em desenvolvimento no comércio multilateral, bem como antagoniza e divide Norte do Sul e Leste do Oeste na União Europeia.

No que tange à delimitação, este trabalho se debruçará sobre a ocorrência transversal dessa retórica no âmbito do "sistema comercial internacional", enquanto gênero, mais especificamente sobre duas ocorrências altamente polarizadoras: a polêmica da cláusula social no âmbito do "subsistema multilateral" e a controvérsia do destacamento temporário de trabalhadores no seio do "subsistema regional", mais especificamente no contexto de expansão/integração da União Europeia

Assim, em um primeiro momento, far-se-á uma breve digressão histórica e propedêutica da temática, buscando situar e compreender o objeto no contexto do liberalismo comercial, passando brevemente pela teoria das vantagens comparativas para, então, chegarse ao dumping (comercial) e aos direitos antidumping enquanto objetos de estudo da ciência jurídica, lhes investigando a natureza jurídica e a aplicabilidade das normas no tocante aos organismos internacionais, nomeadamente, na Organização Mundial do Comércio (OMC), bem como as distorções as quais são submetidas na medida em que são utilizadas como instrumentos a serviço dos interesses estratégicos da política protecionista praticada pelos países desenvolvidos e políticas desenvolvimentistas a serviço dos interesses dos países em desenvolvimento.

Na sequência, buscar-se-á, a partir do atual contexto de globalização da economia, da consequente abertura comercial, do multilateralismo e da criação de espaços de integração regional, nomeadamente da União Europeia, demonstrar a complexidade da atual situação a fim de apresentar o discurso do dumping social como elemento adulterante da leitura que se pode fazer do ambiente em que se desenrola o comércio internacional, tudo por meio de retórica altamente polarizadora e, por conseguinte, com grande ressonância e visibilidade, de modo a criar todo um ambiente fragmentado, seja opondo países desenvolvidos aos países em desenvolvimento no comércio multilateral, seja via oposição Norte-Sul/Leste-Oeste na 
União Europeia, de modo a culminar em proposições legislativas igualmente simplórias e inaptas a alcançar o âmago dos problemas postos, estes, ademais, por sua abrangência e natureza e, ao contrário do efeito provocado pelo discurso do dumping social, só colmatados via convergência de esforços.

Em arremate, proceder-se-á ao estudo das falhadas tentativas de delimitação do dumping social em si, não com o objetivo de atestar sua validade, mas, ao contrário, para apontar suas inconsistências, de modo a reafirmar a importância do discurso, da retórica, do argumento, da acusação, etc., do dumping social enquanto elemento autônomo. 


\section{DUMPING}

\subsection{O comércio internacional}

Pela doutrina econômica dominante no século XVIII, o mercantilismo, as nações diligenciavam no intuito de aumentar as exportações e restringir as importações visando reter ou estocar ${ }^{1}$ metais preciosos e proteger seus agentes econômicos da concorrência dos produtos importados. No entanto, as teorias clássicas do comércio internacional de Smith (vantagem absoluta) e de Ricardo ${ }^{2}$ (vantagem relativa), as neoclássicas ${ }^{3}$ de Eli Heckscher e Bertil Ohlin e os "novos modelos de comércio internacional", capitaneados por estudiosos como Paul Krugman, Marc Melitz e outros ${ }^{4}$, foram bastante exitosas em demonstrar que, se executada de maneira escorreita, com as devidas intervenções para correção de eventuais distorções ou falhas de mercado, a justa liberalização do comércio é fator importante para o desenvolvimento das nações e o consequente incremento do bem-estar econômico e social de todos $^{5}$.

A intensificação das trocas comerciais entre os Estados foi viabilizada pela regulamentação da atividade mercantil entre as nações que trata de desembaraçar a dinâmica

\footnotetext{
1“'A questão do desenvolvimento económico (as causas da riqueza das nações), é a preocupação central do livro de Adam Smith, para quem a riqueza de um país deixou de ser o estoque acumulado em um certo momento para ser apresentada como fluxo do rendimento nacional produzido ao longo de período sucessivos" (NUNES, António Avelãs. (2013). Noção e objecto da Economia Política. Coimbra: Almedina, pp. 64-65).

2"Under a system of perfectly free commerce, each country naturally devotes its capital and labour to such employments as are most beneficial to each. This pursuit of individual advantage is admirably connected with the universal good of the whole. By stimulating industry, by rewarding ingenuity, and by using most efficaciously the peculiar powers bestowed by nature, it distributes labour most effectively and most economically: while, by increasing the general mass of productions, it diffuses general benefit, and binds together by one common tie of interest and intercourse, the universal society of nations throughout the civilized world. It is this principle which determines that wine shall be made in France and Portugal, that corn shall be grown in America and Poland, and that hardware and other goods shall be manufactured in England" (Ricardo, D. (2004). On the Principles of Political Economy and Taxation (Kindle Locations 1223-1229). Library of Alexandria. Kindle Edition).

${ }^{3}$ Para os suecos Eli Heckscher e Bertil Ohlin, a vantagem comparativa se dá pelo benefício que os países ricos têm de exportar bens intensivos em capital como os industrializados, ao passo que os países que detêm abundância em mão de obra (trabalho intensivo) têm vantagem em exportar produtos agrícolas, por exemplo. ${ }^{4}$ Às teorias clássicas e neoclássicas foram incorporados novos elementos como o comércio interindustrial, as economias de escala, as políticas macroeconômicas, etc. Cf. Amador, J. (2017). Portugal e o Comércio Internacional. Lisboa: Fundação Francisco Manuel dos Santos, pp. 19-22.

${ }^{5}$ A abertura comercial, por si só, não irá trazer o desenvolvimento; trata-se, a bem da verdade, de um fator muito importante, quiçá indispensável. No entanto, para se alcançar tal fim, impreterível a boa atuação dos Estados por meio de políticas efetivas nas infraestruturas, nos políticas de fomento à educação, redistribuição de renda etc. Cf. Gava, R. (2008). Ricos \& Mendazes: O Dilema das Cláusulas Sociais nas Relações Multilaterais de Comércio Internacional. Coimbra: Almedina, p. 87.
} 
dos fluxos comerciais internacionais por meio da retirada ou redução das barreiras alfandegárias e não alfandegárias existentes entre os países, permitindo, em tese, que cada nação tire o máximo proveito de suas vantagens comparativas, o que, no entanto, aumentou a competição internacional em determinados setores ${ }^{6}$.

Dessa forma, em 1944, pouco antes do fim da Segunda Guerra, foi firmado em Bretton Woods um acordo que ambicionava reestruturar a economia mundial através de três organismos internacionais: o Banco Internacional para Reconstrução e Desenvolvimento (BIRD ou Banco Mundial), objetivando a reconstrução dos países devastados pela guerra; o Fundo Monetário Internacional (FMI), cujo objetivo é promover ações visando à estabilidade cambial e assistir os países atingidos por crises econômicas; e a Organização Internacional do Comércio (OIC) que buscaria, por meio de acordos internacionais, promover a liberalização do comércio internacional.

De todas essas instituições, só a OIC, "a primeira tentativa de institucionalizar uma ligação entre o comércio internacional e os direitos laborais" ${ }^{\text {, }}$, não veio a se concretizar em razão de veto no âmbito do congresso dos EUA. Diante do insucesso, surgiu, por meio da Carta de Havana, em 1947, o Acordo Geral sobre Tarifas Aduaneiras e Comércio (General Agreement on Tariffs and Trade - GATT). Segundo Portela: "o GATT pode ser abordado por dois aspectos: um tratado voltado a regular o comércio internacional; e o organismo encarregado de velar pela aplicação de suas normas, o qual, no entanto, se limitava a ser uma mera secretaria, sem personalidade jurídica" $"$.

O Direito do Comércio Internacional, na prática inaugurado pelo $\mathrm{GATT}^{9}$, tem por finalidade regular a atividade mercantil entre as nações, buscando fomentar e desembaraçar

\footnotetext{
${ }^{6}$ Neste ponto, Porto lembra que os próprios autores pertencentes à escola clássica já apontavam ao menos duas exceções ao pensamento livre-cambista: "argumento dos termos de comércio" e o "argumento das indústrias nascentes", ou seja, para melhorar preços internacionais (termos ou razoes de trocas) ou para "promover o aparecimento de uma ou várias novas indústria ou da indústria em geral" (Porto, M. C. L. (2017). Teoria da integração e políticas da União Europeia: Face aos desafios da globalização. 5. ed. Coimbra: Almedina, pp. 39-40).

${ }^{7}$ As palavras em destaque são de Vital Moreira, que segue lembrando o fato de que "a Carta [de Havana de 1947] estabelecia uma explícita conexão entre comércio internacional e condições de trabalho dignas ("fair labour standars", tal era a rubrica do art..$\left.^{\circ}\right)$, mediante uma cláusula vinculativa que podia dar lugar a queixas junto do "mecanismo de resolução de litígios" da OIC, a par de queixas em matéria comercial propriamente dita (Moreira, V. (2014). Trabalho digno para todos: A "cláusula laboral” no comércio internacional na União Europeia. Coimbra: Coimbra Editora, p. 96).

${ }^{8}$ Portela, P. H. G. (2016). Direito Internacional Público e Privado: Incluindo Noções de Direitos Humanos e de Direito Comunitário. 8. ed. Salvador: JusPodivm, p. 418.

${ }^{9}$ Ibid.
} 
a dinâmica dos fluxos comerciais internacionais por meio da retirada ou redução das barreiras alfandegárias e não alfandegárias existentes entre os países ${ }^{10}$.

Com o passar do tempo, alguns dispositivos do GATT sofreram alterações ou foram complementados durante os ciclos de negociações, conhecidos por rondas ou rounds. Desde a criação do GATT, foram oito os ciclos de negociação: Ronda de Genebra (1947), Ronda de Annecy (1949), Ronda de Torquay (1950-1951), Segunda Ronda de Genebra (19551956), Ronda de Dillon (1959-1962), Ronda de Kennedy (1964-1967), Ronda de Tóquio (1973-1979), Ronda do Uruguai (1986-1993) e Ronda de Doha (2001 - ).

A Ronda do Uruguai foi, sem dúvidas, a mais destacada, pois trouxe grandes modificações, incluindo o Acordo Antidumping da Ronda do Uruguai (AARU). A ata final da Uruguai Round, a Ata de Marraqueche, foi finalizada em 1994, convertendo o tratado GATT (de 1947) no chamado GATT 1994 e substituindo o GATT, enquanto instituição, pela Organização Mundial do Comércio $(\mathrm{OMC})^{11}$.

Naquele momento, crescia o pensamento fundamentado nas ideias de Smith, Ricardo, Heckscher, Ohlin e outros, de que a liberalização do comércio internacional seria a chave para o progresso e da paz entre as nações, "na medida em que os recursos são transferidos de sectores protegidos, em um país que não tem vantagem comparativa, para sectores onde é mais eficiente e onde pode exportar com mais sucesso ${ }^{12}$,, contudo, na prática, apesar de ser consenso que a liberalização comercial cria oportunidades para o desenvolvimento econômico, a concretização dessa tendência está atrelada a outros fatores.

Nesse intento, Stiglitz e Chalton destacam o fato de que certos países desenvolvidos se mostram “ardentes defensores da liberalização comercial ${ }^{13}$ ", todavia:

[...] têm negociado a redução de direitos aduaneiros e a eliminação de subsídios sobre os bens nos quais têm uma vantagem comparativa, mas são relutantes em abrir os seus próprios mercados e em eliminar os seus subsídios nas áreas em que os países em vias de desenvolvimento têm uma vantagem ${ }^{14}$.

\footnotetext{
${ }^{10}$ Portela, 2016, pp. 417-418.

${ }^{11}$ Não confundir com Organização Internacional do Comércio (OIC).

${ }^{12}$ Stiglitz, J. E. \& Charlton, A. (2009). Comércio Justo para Todos: como o comércio pode promover o desenvolvimento. Tradução: Jacqueline Sandra. Lisboa: Texto Editores, p. 45.

${ }^{13}$ Ibid., p. 50.

${ }^{14}$ Ibid., p. 51.
} 
Noutra senda, "atrasos tecnológicos, grupos de trabalhadores demasiado pequenos para gerar economias de escala, custos altos de transporte e comercialização, infraestrutura pobres, instituições estatais pouco eficientes, e falta de mão de obra especializada" ${ }^{15}$ figuram entre os gargalos na capacidade competitiva dos países em vias de desenvolvimento.

\subsection{O Sistema Comercial Internacional}

Luís Pedro Cunha, em obra de referência no tema, trata, de pronto, de desfazer recorrente confusão dentre os estudiosos do comércio internacional que imputam correspondência entre "sistema comercial internacional" e "sistema comercial multilateral"16. Para o autor, o segundo é, na verdade, subsistema do primeiro.

Em vista disso, o "sistema comercial internacional" comporta quatro subsistemas: "subsistema multilateral", que alberga as regras multilaterais de comércio ${ }^{17}$; um segundo subsistema de cariz majoritariamente protecionista que se pauta no bilateralismo e unilateralismo; um terceiro, que abriga o regionalismo, instrumentalizado via acordos de integração regional; e o quarto, comportando "acordos ou compromissos bilaterais, plurilaterais e multilaterais, frequentemente suscitados por preocupações reais ou aparentes de fair trade" 18 .

$\mathrm{O}$ autor acrescenta ainda que "a estes quatro subsistemas acresce ainda legislação de cada economia, adoptada autonomamente, mesmo que no respeito e na sequência de acordos internacionais", citando como exemplo a "regulamentação sobre tributação antidumping ou compensadora, ou sobre o valor aduaneiro, ou ainda sobre segurança dos produtos, etc." $" 19$.

Neste ponto, insta lembrar que a presente dissertação, por não pretender exaurir o tema proposto, aborda a questão do discurso do dumping social através da análise de questões que se desenvolvem em apenas dois desses subsistemas componentes do sistema comercial internacional: a primeira no subsistema multilateral de comércio internacional, notadamente no movimento que contrapôs países desenvolvidos e países em

\footnotetext{
${ }^{15}$ Stiglitz, 2009, p. 45.

${ }^{16}$ Cunha, L. P. (2008). O Sistema Comercial internacional e os espaços de integração regional. Coimbra: Coimbra Editora, p. 11.

${ }^{17}$ Cunha, L. P. (1997). Relações Económicas Externas. Coimbra: Almedina, p. 201.

${ }^{18}$ Cunha, op. cit., p. 13.

${ }^{19}$ Ibid.
} 
desenvolvimento no âmbito do sistema GATT/OMC e que culminou com a polêmica das chamadas "cláusulas sociais" e a segunda que, por sua vez, diz respeito ao subsistema regional de comércio internacional, nomeadamente no que tange ao destacamento de trabalhadores no âmbito do mercado comum da União Europeia. No entanto, há que se aclarar que o fenômeno do discurso do dumping social não se restringe aos dois exemplos abordados logo mais adiante.

\subsubsection{O multilateralismo}

O subsistema multilateral de comércio corresponde às regras multilateralmente negociadas do sistema GATT/OMC devidamente evoluídas nas sucessivas rondas, sempre visando a eliminação das barreiras ao livre-cambismo entre as nações, cujas elaboração e aplicação se norteiam por princípios fundamentais como o "princípio da não discriminação", “o princípio da redução generalizada e progressiva dos impostos alfandegários”, “o princípio da proibição das restrições quantitativas" e o "princípio da reciprocidade" 20 .

Cunha lembra ainda que "o princípio da não discriminação contém duas cláusulas: 'a cláusula da nação mais favorecida' e a cláusula do 'tratamento nacional"”21 - a primeira visa afastar a discriminação pautal de uma determinada mercadoria (ou serviço) em razão da sua origem, evitando justamente o favorecimento de uma nação em detrimento das demais; enquanto isso, a segunda:

[...] tem tradicionalmente cabido a função de evitar que regulações ou imposições internas produzam acréscimos de discriminação entre o conjunto das mercadorias importadas e a produção do país importador, para além daquela que, em circunstâncias normais, decorre da tributação alfandegária prevista na pauta aduaneira $^{22}$.

\subsubsection{O Protecionismo}

\footnotetext{
${ }^{20}$ Cunha, L. P. (2002). A Integração Regional e o Sistema Comercial Multilateral face à Globalização: convergência ou rivalidade?. In: Revista Brasileira de Direito Comparado, n. 22, Rio de Janeiro, pp. 257-259.

${ }^{21}$ Ibid., p. 259

${ }^{22}$ Idem, 2008, p. 16-17.
} 
O segundo subsistema abrange os acordos ou compromissos que visam resguardar setores sensíveis da produção por meio, por exemplo, do uso de "medidas comerciais unilaterais adotadas por vários países com intuitos igualmente restritivos, à margem (ou, eventualmente, ao arrepio) dos princípios do GATT e da OMC"23.

\subsubsection{O Regionalismo}

Ao terceiro subsistema:

[...] correspondem os acordos de integração regional que constituíram, por exemplo, a Comunidade Europeia, o CUSFTA, o ANZCERTA, a NAFTA, ou o MERCOSUL, e medidas (de impacto regional), previstas em acordos ou adaptadas unilateralmente, que contemplam geralmente a concessão de preferências alfandegárias e que, cada vez mais, tendem a entrar noutros domínios que garantem integração económica ${ }^{24}$.

\subsubsection{O Fair Trade}

São temas "que respeitam a matérias tradicionalmente tratadas nas ordens jurídicas nacionais, mas que produzem também seus efeitos no comércio internacional" ${ }^{25}$, como também:

[...] frequentemente são resultado de pressões dos países desenvolvidos sobre os países subdesenvolvidos. Pense-se nos casos da legislação de defesa da concorrência, relacionada com a protecção do investimento ou da propriedade intelectual, com os direitos dos trabalhadores ou ainda com a salvaguarda do ambiente ${ }^{26}$.

\subsection{Defesa comercial e dumping}

Defesa comercial é o ramo do Direito Internacional Econômico que regula a utilização de "barreiras não tarifárias a produtos importados do exterior e são utilizados, pelo Estado para proteger a indústria doméstica dos danos causados por práticas desleal de

\footnotetext{
${ }^{23}$ Cunha, 2008, p. 12.

${ }^{24}$ Ibid.

${ }^{25}$ Cunha, L. P. (2001). Standards Sociais e Ambientais no Comércio Internacional. In: Boletim de Ciências Económicas da Faculdade de Direito da Universidade de Coimbra, vol. XLIV, Coimbra, p. 4.

${ }^{26}$ Idem, 1997, p. 201.
} 
comércio ou pelo crescimento imprevisto das importações" 27 , bem como o processo de investigação, unilateral ou multilateral, a legitimar a aplicação de tais instrumentos. São unilaterais as medidas de salvaguarda, as compensatórias e as antidumping; são multilaterais as retaliações ou suspensão de benefícios previamente acordados por meio da $\mathrm{OMC}^{28}$.

Bliacheriene destaca que o GATT, por meio do seu art. VI.5, trata de proibir a adoção de medidas de defesa comercial de maneira cumulativa, e segue afirmando que essas medidas "têm tripla função: compensar um dano efetivamente sofrido, inibir um dano potencial ou, ainda, inibir que essas práticas danosas sejam recorrentes (intuito preventivo)" 29 .

As medidas compensatórias são reservadas a compensar ou anular subsídios concedidos pelo Estado à sua indústria exportadora que venham a causar ou ameaçar causar dano à indústria do país importador ${ }^{30}$.

As medidas de salvaguardas são aquelas aplicadas quando da ocorrência de "um surto de importação de produto similar ao produzido pela indústria doméstica, que esteja causando ou possa causar grave prejuízo à indústria local"31, de modo que são:

aplicadas pelo Estado membro da $\mathrm{OMC}$, a pedido do setor relevante afetado, visando dar uma proteção adequada e temporária a esse setor afetado por um aumento imprevisível, em termos absolutos e relativos, de importações de produtos concorrentes [...]. Não são utilizadas com intuito de proteger a indústria doméstica contra uma prática desleal de comércio internacional [...]. Na realidade, seu objetivo é proteger, temporariamente, um setor econômico afetado $[\ldots]^{32}$.

Ainda no que tange às medidas de salvaguarda, Bliacheriene explica que:

Há ainda as salvaguardas específicas que se diferenciam das salvaguardas gerais nos seguintes pontos: a) há seletividade do país ao qual se destinam; b) é desnecessária a prova de prejuízo grave, sendo cabível a prova de mera desorganização do mercado; c) não é exigível um programa de ajustamento progressivo da indústria

\footnotetext{
${ }^{27}$ Jorge, D. M. (2015). Direito antidumping \& comércio internacional: medidas antidumping para o desenvolvimento econômico e proteção da indústria doméstica. Curitiba: Juruá, p. 199.

${ }^{28}$ Ibid.

${ }^{29}$ Bliacheriene, A. C. (2007). Defesa Comercial. São Paulo: Quartier Latin, p. 45.

${ }^{30}$ Ibid.

${ }^{31}$ Ibid., p. 46.

${ }^{32}$ Jorge, op. cit., p. 203.
} 
nacional; e d) é obrigatória a formulação de consultas preliminares com o país exportador, antes de sua aplicação ${ }^{33}$.

Por fim, os direitos ou medidas antidumping são aplicados nos casos comprovados de ocorrência de dumping (ambos serão abordados em pormenor mais adiante). Insta destacar a fala de Geraldello que, a partir dos ensinamentos de Thorstensen, assevera que:

[...] como a salvaguarda e os subsídios exigem uma contrapartida do país importador, as medidas antidumping tornam-se mais ágeis e eficientes na busca de proteção, pois são um mecanismo seletivo contra um país ou empresa que não exige compensações e permite uma maior flexibilidade de interpretação ${ }^{34}$.

O sistema multilateral de comércio da OMC trata de regulamentar as medidas de defesa comercial por meio de diversos acordos com destaque para o Acordo sobre Subsídios e Medidas Compensatórias (ASMC), o Acordo sobre Salvaguardas (ASS) e o Acordo Antidumping da Ronda do Uruguai (AARU) ${ }^{35}$.

\subsubsection{A delimitação do dumping}

$\mathrm{Na}$ medida em que o mercado foi se tornando cada vez mais concorrido e global, muitos Estados estimulam e/ou facilitam que empresas nacionais adotem "práticas heterodoxas de mercado" 36 como exportar suas mercadorias a um preço artificialmente baixo visando provocar um desequilíbrio naquele mercado receptor para, ao fim, dominá-lo via eliminação de adversários (monopolização).

Desde Adam Smith ${ }^{37}$ são proferidos discursos criticando a prática supra descrita; destarte, aponta-se que Alexander Hamilton, primeiro Secretário do Tesouro dos Estados Unidos da América, em 1791, já fazia uso da palavra "dumping” em seus debates, contudo, só nos idos de 1922 e 1923, quando o economista canadense Jacob Viner, por suas obras

\footnotetext{
${ }^{33}$ Bliacheriene (2007, p. 46) explica previamente que, nas salvaguardas gerais, "exige-se que a indústria doméstica adote um programa progressivo de competitividade que será acompanhado pelo governo até que cesse a aplicação da medida de salvaguarda".

${ }^{34}$ Geraldello, C. S. (2015b). As medidas antidumping na Organização Mundial do Comércio e os constrangimentos aos Estados Unidos. In: Boletim Meridiano 47, vol. 16, n. 151, pp. 18-28. Disponível em: $<$ https://www.researchgate.net/publication/293042487_As_medidas_antidumping_na_Organizacao_Mundial do Comercio e os constrangimentos aos Estados Unidos $>$. Acesso em: 29 abr. 2019.

${ }^{35}$ World Trade Organization. Disponível em: $<$ https://www.wto.org $>$. Acesso em: 20 abr. 2018.

${ }^{36}$ Bliacheriene, op. cit., p.43.

${ }^{37}$ Bastos, E. L. (2012). Estudo analítico do dumping na esfera internacional. Curitiba: Juruá, p. 19.
} 
"Dumping as a Method of Competition in International"38 e "Dumping: A Problem in International Trade" 39 , associou, de forma mais acurada, o termo "dumping" 40 à ideia de uma empresa oferecer o mesmo bem a um preço mais baixo no mercado externo do que no mercado local ${ }^{41}$ e foi com isso que tal ideia se consolidou e despertou, entre os economistas, a necessidade de proteção da indústria doméstica ${ }^{42}$.

Assim, o termo "dumping", em economia, vem sendo sempre associado à noção de competição injusta ou concorrência desleal entre as nações, via discriminação de preços ${ }^{43}$ nas exportações, de modo a possuir "uma conotação pejorativa, induzindo ao sentido de comportamento negativo ou condenável" 44 .

Juridicamente, a definição de dumping fica a cargo do Acordo Geral sobre Tarifas Aduaneiras e Comércio (GATT), que o delimita como a prática segundo a qual "os produtos de um país são introduzidos no comércio de outro país por menos que o valor normal dos produtos" e "deve ser condenado se causa ou ameaça causar prejuízo à indústria local ou retarda substancialmente o estabelecimento de indústria nacional"45.

\footnotetext{
${ }^{38}$ Viner, J. (1922). Dumping as a Method of Competition in International. In: The University Journal of Business. Chicago, EUA, vol. I, n. 1. Disponível em:

$<$ http://www.jstor.org/stable/2354748?seq=2\#page scan tab contents $>$. Acesso em: 13 mar. 2018.

${ }^{39}$ Viner, J. (1924). Dumping: A Problem in International Trade. In: Chicago University Press. Chicago, vol. 32, n. 4. Disponível em: <https:/www.journals.uchicago.edu/doi/pdfplus/10.1086/253614>. Acesso em: 13 mar. 2018.

${ }^{40} \mathrm{O}$ termo "dumping" é um vocábulo em inglês que vem do verbo "to dump" e transmite a ideia de "deitar algo fora", descarregar, e no comércio designa a ideia despejar um determinado produto no mercado, inundando-o, visando prejudicar os concorrentes, servindo a um propósito monopolista, conforme Barral: "A Concepção atual de dumping se caracteriza por grande abrangência na aplicação do termo e pela fragilidade de critérios técnicos, quando de sua caracterização na prática comercial, sobretudo entre o público leigo. Desta forma, o conceito sofre compreensão diversa não apenas na linguagem jurídica e na econômica, mas também é empregado corriqueiramente para designar práticas, ou situações, que tecnicamente não constituem dumping" (Barral, W. (2000). Dumping e comércio internacional: a regulamentação antidumping após a rodada do Uruguai. Rio de Janeiro: Forense, pp. 7-8).

${ }^{41}$ Bouet, A. (1998). Le protectionnisme. Analyse économique. Paris: Lebrairie Vuibert, p. 125.

${ }^{42}$ Jorge, 2015, p. 113.

${ }^{43}$ Bastos (op. cit., p. 21) esclarece que o price disccrimination ocorre quando "existe diferença de preço de um mesmo vendedor, não se levando em conta diferenças de custos ou mudanças no nível de demanda, ou quando dois tipos ou mais de compradores pagam o mesmo preço, apesar de custos diferentes".

${ }^{44}$ Barral, op. cit., loc. cit.

45"Article VI: Anti-dumping and Countervailing Duties. The contracting parties recognize that dumping, by which products of one country are introduced into the commerce of another country at less than the normal value of the products, is to be condemned if it causes or threatens material injury to an established industry in the territory of a contracting party or materially retards the establishment of a domestic industry. For the purposes of this Article, a product is to be considered as being introduced into the commerce of an importing country at less than its normal value, if the price of the product exported from one country to another" (World Trade Organization. The General Agreement on Tariffs and Trade (GATT 1947). Disponível em: $<$ https://www.wto.org/english/docs_e/legal_e/gatt47_01_e.htm\#art6>. Acesso em: 01 abr. 2019).
} 
Assim, o dumping, para o Direito, ocorre quando o preço de exportação do produto é inferior ao preço de venda no mercado interno do país exportador. Porém, para ser condenável, a diferença de preços deve acarretar dano relevante à indústria ou à industrialização do país importador ${ }^{46}$.

Diante disso, a leitura do artigo VI do GATT permite diferenciar dois tipos de dumping: o condenável e o não condenável. No primeiro, considera-se as práticas desleais de comércio internacional que venham a causar danos à indústria interna do país importador, ao passo que o segundo, não condenável, é a prática de dumping sem que dela advenha prejuízo às indústrias locais ou ao estabelecimento de indústrias no país receptor ${ }^{47}$.

Isto posto, de forma geral, a doutrina destaca o que conveniou chamar de "intuito predatório" como elemento definidor do dumping condenável, prevendo que a prática pode ter por objeto a eliminação da concorrência e a consequente monopolização de um determinado mercado. Por conseguinte, à rigor, só há que se falar em dumping condenável (ou predatório) nas situações em que o exportador de um determinado país vende produto ao país importador por um preço menor que o valor de um produto similar no seu mercado interno ou, na falta deste, menor que o valor cobrado a um terceiro país importador, desde que, como já dito, essa prática cause danos a um ramo de produção do país receptor ${ }^{48}$ ou mesmo impeça ou retarde seu surgimento.

Visando facilitar a caracterização da prática do dumping, a doutrina tratou de destacar o que ficou convencionado como "valor normal" da mercadoria, sendo este resultado da apuração de uma série de variáveis a fim de concluir se o país exportador está promovendo um valor artificial às suas mercadorias ${ }^{49}$.

Quando da ocorrência do dumping condenável, um país pode adotar medidas visando proteger sua indústria doméstica (estabelecida ou por estabelecer) através de "barreiras não tributárias à importação de produtos do exterior”, ou seja, de uma

\footnotetext{
${ }^{46}$ Neste ponto, cabe destacar "o argumento das indústrias nascentes", cuja ideia é a de que "a indústria pode vir a revelar-se capaz de competir com as indústrias estrangeiras dentro de um espaço de tempo previsível, no mercado doméstico e mesmo no mercado internacional, mas não ser capaz de suportar um período inicial de implementação e desenvolvimento" (Porto, 2017, pp. 162-178).

${ }^{47}$ Barral, 2000, p. 34.

${ }^{48}$ Ibid., p. 12.

${ }^{49}$ Campus, J. M. (coord.). et al. Organizações Internacionais. Teoria Geral. Estudo Monográfico das Principais Organizações Internacionais de que Portugal é membro. Lisboa: Fundação Calouste Gulbenkaian, 1999, p. 351) apud Dutra, L. P. B. (2016). Dumping social no direito do trabalho e no direito econômico. Curitiba: Juruá, p. 69.
} 
"modalidade não tributária de intervenção no domínio econômico"50 conhecida como medidas ou direitos antidumping.

Jorge, citando o entendimento de Barral, assevera que, embora a visão econômica não corresponda integralmente ao fundamento jurídico do dumping, a "única fundamentação econômica coerente para a aplicação das medidas antidumping [...] seria a hipótese de preço predatório", pois "se o intuito é proteger o mercado interno, a medida correta seria a de salvaguarda ${ }^{51}$ e não a antidumping”, e segue afirmando que o argumento do dumping não pode ser utilizado para "proteger indústrias nacionais ineficazes com grande poder político, ou para atender a pressões de sindicatos de trabalhadores" 52 .

Dessa maneira, a simples ocorrência de dumping não constitui ato censurável ${ }^{53}$, pois, ainda que um país receba, via importação, um produto abaixo do preço, dito normal, se a mesma não tiver o condão de prejudicar a indústria instalada ou potencialmente vindoura, não há que se queixar, posto que vai contribuir com o processo de atomização dos produtos e otimização dos preços, bem como servir de input na cadeia de produção nacional, de modo que até se pode falar em dumping mas não em medidas antidumping, uma vez que inexiste relação de causalidade entre o preço da mercadoria e um dano (real ou potencial) à indústria do país receptor.

$\mathrm{Na}$ verdade, em que pesem opiniões contrárias $^{54}$, merece prosperar a doutrina de Jorge que, citando Barral, aponta a natureza jurídica do dumping como "fato jurídicoeconômico", já que o dumping é fundamentado em normas de Direito Econômico Internacional (que pode irradiar para os Direitos Econômicos internos) e a sua aplicação caracteriza uma "intervenção estatal no domínio econômico" embasada na proteção da atividade industrial de uma nação ${ }^{55}$.

\footnotetext{
${ }^{50}$ Jorge, 2015, p. 122.

51 "Mecanismos excepcionais, previstos pelo ordenamento da OMC, por meio dos quais é conferida a um Membro a possibilidade de suspensão de suas obrigações [...], durante um período limitado de tempo que se faz necessária para que esse Membro possa proteger sua economia ou seus produtores nacionais, que estão sofrendo ou em vias de sofrer algum tipo de prejuízo" (Brogini, G. D. (2004). OMC e a indústria nacional: as salvaguardas para o desenvolvimento. São Paulo: Aduaneiras, pp. 86-87. apud Bliacheriene, 2007, p. 44).

${ }^{52}$ Jorge, op. cit., p. 140.

${ }^{53}$ Barral, 2000, p. 58.

${ }^{54}$ Há quem defenda que o dumping tem natureza jurídica de ato ilícito, tese, data vênia, já afastada neste texto, bem como a hipótese de que se trata de "abuso de poder econômico", posto que, na verdade, condutas anticoncorrenciais são objeto do direito antitruste cuja diferenciação em relação aos direitos antidumping se procederá na sequência do presente trabalho. Para saber mais sobre a natureza jurídica do dumping, cf. Jorge, op. cit., pp. 117-120.

${ }^{55}$ Ibid., p. 36.
} 


\subsubsection{A determinação do dumping}

Pela Rodada do Uruguai chegou-se ao "Acordo sobre a Implementação do Artigo VI do GATT 94” ou “Acordo Antidumping da Rodada do Uruguai (AARU)”, cujo objetivo é estabelecer uma metodologia comum a ser utilizada para a determinação do dumping.

Isto posto, merece destaque o artigo $2 .^{\circ}$ do AARU que se destina à verificação da existência de dumping condenável impondo alguma acurácia a conceitos como "valor normal" de um produto; "margem de dumping"; "produto similar"; "determinação de dano ou ameaça" e do respectivo "nexo causal"; bem como ficaram estabelecidos os procedimentos a serem seguidos na abertura e condução de investigações antidumping e, também, da implementação e duração de medidas antidumping ${ }^{56}$.

\subsubsection{Valor normal}

Se o dumping ocorre quando da importação de um produto ou serviço a preço abaixo do dito "normal", a primeira empreitada que se impõe é a delimitação do que seria preço ou "valor normal" para fins de apontar a ocorrência de dumping.

Para $\operatorname{Bastos}^{57}$, a chave para tal entendimento está na compreensão da chamada "discriminação de preços" que, segundo ele, se dá quando um determinado produto ou serviço é comercializado por "um mesmo vendedor" a preços diferentes a depender do comprador, levando em consideração "diferenças de custos ou mudanças no nível da demanda" ou, à despeito de custos diferentes, os adquirentes pagam o mesmo preço. Quando da análise da diferenciação de preços entre o mercado interno e o internacional, deve se ter em conta uma série de variáveis nos custos como transporte, embalagens, seguro, economia de escala em razão do volume transacionado, o período, etc.

Para fins de determinação de dumping, a discriminação de preços deve ocorrer no sentido de preços deliberadamente menores para exportação tendo como base o praticado no mercado interno, de modo a ter o condão de ameaçar competidores eficientes no mercado

\footnotetext{
${ }^{56}$ Brasil. Ministério da Economia, Indústria, Comércio Exterior e Serviços. Acordos da OMC: Acordo sobre a Implementação do Artigo VI do Acordo Geral Sobre Tarifas e Comércio 1994. Disponível em: $<$ http://www.mdic.gov.br/comercio-exterior/negociacoes-internacionais/1885-omc-acordos-da-omc $>$. Acesso em: 22 mar. 2018.

${ }^{57}$ Bastos, 2012, pp. 21-22.
} 
exportador, normalmente pela prática de preços não compatíveis com seus custos marginais ${ }^{58}$.

Ferreira destaca ainda as situações de "underselling", ou seja, aquelas em que um produtor vende sua mercadoria por preço inferior ao custo de produção, circunstância que, por si só, não se deve confundir com dumping ou pelo menos com dumping condenável já que, em grande parte dos casos, não se verifica o intuito de dominação do mercado importador e/ou prejuízo ou ameaça à indústria doméstica do mercado importador. $\mathrm{O}$ "underselling" tende a ser prática esporádica, emergencial - é comum, por exemplo, em situações de crise na demanda que provocam acúmulo imprevisto de estoque ${ }^{59}$.

Já o preço predatório é uma espécie de discriminação de preços que se destina especificamente a prejudicar competidores eficientes, seja para eliminá-lo do mercado, compeli-lo a colaborar com práticas de cartelização, impedir o ingresso de novos competidores e outros. Importa alertar que tal prática não se configura tão facilmente, pois, para isto, o praticante deve deter considerável "poder de mercado" e o produto em tela precisa ser bastante "elástico" 60 .

A partir dos conceitos supra apresentados, deve-se ter em mente que poderá haver casos em que o preço baixo se justifica, por exemplo, por crise econômica que veio a causar grandes estoques ou diminuiu os custos de produção. Da mesma forma, também os chamados preços predatórios não implicam necessariamente em dumping condenável, pois este possui requisitos específicos como o prejuízo ou ameaça à indústria doméstica do país receptor da mercadoria ou serviço dumped ${ }^{61}$.

Destarte, para Barral: "valor normal equivale ao preço de produto similar no mercado exportador; a comparação justa se fará entre o preço de exportação e o valor normal; desta comparação exsurge a margem de dumping"62.

\footnotetext{
${ }^{58}$ Bastos, 2012, pp. 21-22.

${ }^{59}$ Ferreira, C. A. (2009). Os Impactos da Prática de Dumping no Comércio Internacional. In: Revista Eletrônica da Faculdade de Direito da PUC - SP, n. 2. Disponível em:

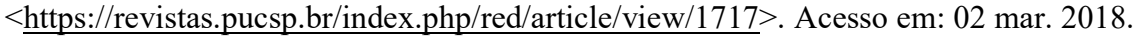

${ }^{60}$ Neste caso, implica afirmar que a demanda por determinado produto é demasiadamente influenciada pelo preço.

${ }^{61}$ Expressão que, em tradução nossa, refere-se ao produto ou serviço eivado de dumping, destacamos porque, ao contrário de "dumping", não há consenso na doutrina de que tal vocábulo esteja incorporado ao português. ${ }^{62}$ Barral, 2000, pp.179-180.
} 
Ademais, importante mesmo é se ater ao artigo VI do GATT pelo qual "valor normal" seria o preço do mesmo produto ou seu similar ${ }^{63}$ em condições normais de comércio e volume significativo, praticado ao consumidor no mercado interno do país exportador ou, eventualmente, o preço de exportação praticado por outro país ou mesmo seu custo de produção.

\subsubsection{Margem de dumping}

Da comparação entre o valor normal e o preço de exportação, na mesma fase comercial e em datas próximas, se extrai a chamada "margem de dumping". Pelo artigo 2.6 do AARU, essa margem advém da "comparação entre o valor normal médio ponderado de todas as exportações equivalentes ou com base nas comparações entre o valor normal e os preços de exportação apurados em cada transação [...]".

A margem de dumping é considerada de minimis ${ }^{64}$, ou seja, para se configurar dumping o preço do produto ou serviço, bem como o volume de importações e o prejuízo à indústria doméstica, hão de ser significantes, por exemplo, o artigo 5.8 do Acordo Antidumping da Rodada do Uruguai determina que será de minimis a margem de dumping que não alcançar uma diferença de $2 \%$ entre o preço de exportação e o "normal", casos em que uma investigação deverá ser encerrada ${ }^{65}$.

A apuração da ocorrência de dumping é, em tese, bastante mais complexa do que aparenta, pois, conforme esclarece Barral, há que considerar uma série de variáveis como qualidade do objeto, quantidade transacionada, o momento (época ou estação) da venda, tributos incidentes, custos de transporte, câmbio, etc. ${ }^{66}$, fatores eivados de opacidade, altamente manipuláveis que conferem, na prática, grande margem de discricionariedade aos agentes que atuarão na determinação do dumping no caso concreto.

\footnotetext{
${ }^{63}$ Pelo artigo 2.8 do AARU, "similar" seria um produto idêntico, "igual em todos os aspectos" ao exportado ou com "características muito próximas" ao do produto examinado. Nas palavras de Jorge (2015, p. 135): "não se pode interpretar de forma ampla o termo 'produto similar', não sendo admissível a consideração de produtos de classes diferentes, com qualidade por vezes superior, os quais podem ter um preço mais elevado no mercado doméstico, mas também não se deve interpretar de maneira muito estrita, para que não se distancie do verdadeiro intuito da norma".

${ }^{64}$ Expressão latina que significa “do mínimo".

${ }^{65}$ Bliacheriene, 2007, p. 260.

${ }^{66}$ Barral, 2000, pp. 36, 178, 179, 189 e 190.
} 


\subsubsection{Configuração do dano e nexo causal}

Conforme já explanado, para que se confirme a incidência de dumping condenável é imprescindível que se ateste a ocorrência de dano à indústria nacional estabelecida ou ameaça ao estabelecimento de segmento industrial correspondente ao produto dumped no país importador.

Além disso, é indispensável a demonstração do nexo causal entre a prática do dumping (conduta) e a lesão ou ameaça de lesão ao setor industrial do país importador (resultado), mediante elementos de prova em procedimento regular amparado pelo acordado no GATT e no AARU.

Para fins de dumping, o AARU impõe à expressão "indústria doméstica" um sentido jurídico específico, apontando os produtores nacionais em conjunto, com produção somada significante frente ao total produzido pelo país. Já o termo "produtores nacionais" designa todos "aqueles que fabricam, no território do membro da $\mathrm{OMC}$, produto similar àquele investigado" 67 .

À vista disso, insta relembrar que somente mediante comprovação da ocorrência de dumping condenável é autorizada a aplicação de medidas antidumping, ou seja, há que ficar determinada a existência de dano ou ameaça de dano à indústria nacional ou o prejuízo relativamente ao futuro estabelecimento de indústria nacional no seguimento produtivo de onde advém o produto ou serviço objeto de dumping.

Outrossim, há que se demonstrar o nexo causal entre as importações do produto ou serviço investigado e um dano infligido à indústria doméstica, instalada ou potencial, mediante elementos de prova no âmbito de procedimento que garanta o contraditório ${ }^{68}$.

Neste ponto, é relevante aclarar que o AARU não prevê um mecanismo multilateral para investigação de ocorrência de dumping; o procedimento para aplicação de direitos antidumping decorrem dos acordos da OMC mas, inicialmente, independem dela, pois, a partir do lastro fornecido pelo AARU, os países signatários trataram de internalizar a legislação, de modo que, em geral, os direitos antidumping são aplicados via mecanismos de investigação unilateral conduzidos pelo país importador, normalmente mediante provocação do setor produtivo daquele país, de maneira que o procedimento prévio deve

\footnotetext{
${ }^{67}$ Bliacheriene, 2007, p. 258.

${ }^{68}$ Jorge, 2015, p. 137.
} 
seguir os ditames gerais do AARU, mas não precisa ser antecipadamente submetido à apreciação da OMC.

$\mathrm{Na}$ verdade, comumente os países exportadores que se entenderem prejudicados por imposição de direitos antidumping a suas exportações é que poderão, mediante procedimento próprio junto ao Órgão de Resolução de Conflitos (ORC) da OMC, abrir um painel visando rever o procedimento de verificação de dumping que justificou a aplicação de medidas antidumping às suas exportações.

\subsubsection{Os direitos antidumping}

As medidas ou direitos antidumping são apontadas pela doutrina especializada como sendo "uma modalidade não tributária de intervenção no domínio econômico" na forma de "barreiras não tributárias à importação de produtos do exterior e são utilizados, de maneira discricionária pelo Estado, para proteger a indústria doméstica de eventuais danos causados por práticas desleais de comércio"69.

Quanto à natureza jurídica dos direitos antidumping, adota-se aqui a posição supramencionada, ou seja, a de que estes detêm natureza de "modalidade não tributária de intervenção no domínio econômico", com a ressalva de que há quem os considere "sanção", "tributo" ou mesmo "um mecanismo sui generis de proteção"70.

Não há que se conferir às medidas antidumping um caráter sancionatório, uma vez que a sua aplicação é ato discricionário e soberano do país importador que, mesmo após investigação e comprovação da ocorrência do dumping condenável, não lhe recai obrigação de aplicar as medidas antidumping uma vez que estas não se destinam a punir o país exportador, mas oferecer a possibilidade de o importador proteger sua indústria doméstica.

Pela mesma razão, ou seja, pela discricionariedade na aplicação, se pode afirmar que os direitos antidumping não são tributo, pois não há que se falar em "exigibilidade" ou “compulsoriedade" que são inerentes a estes.

Já a chamada natureza jurídica "sui generis" é normalmente imputada àqueles institutos que não encontram qualquer enquadramento em categoria já existente, o que, data vênia, não ocorre aqui, visto que os direitos antidumping se constituem de instrumentos por

\footnotetext{
${ }^{69}$ Jorge, 2015, p. 137.

${ }^{70}$ Torres, G. C. El dumping: la legislacion argentina y direcho comparado. apud Barral, 2000, p. 122.
} 
meio dos quais o Estado busca intervir na economia, protegendo ou promovendo as indústrias nacionais de práticas por ele consideradas desleais, assim, pode-se concluir que “a natureza jurídica das medidas antidumping é de modalidade não tributária de intervenção do Estado no domínio econômico, fundada na função de incentivo"71.

\subsubsection{Direitos antidumping, direito antitruste e a lógica liberal}

As regras da OMC zelam por um comércio internacional livre, aberto, para que os países produzam aquilo em que tem mais eficiência e que estes produtos circulem com a maior liberdade possível entre todas as nações.

A pragmática liberal que serve de alicerce para o ideário de comércio livre autoriza a concluir que um país não deveria produzir aquilo que pode adquirir a um custo menor, privilegiando, dessa forma, a divisão internacional do trabalho, o aproveitamento pleno das vantagens comparativas e, por conseguinte, da eficiência produtiva.

Nesta lógica, a prática de preços baixos baseados nas condições naturais das nações, aliado à eficiência dos produtores não prejudicaria o comércio internacional, mas, ao contrário, incrementaria o volume total de riquezas produzidas com ganhos também para os consumidores dos países importadores.

Dito isto, não faz sentido a OMC intervir em questões relativas ao dumping se os preços praticados abaixo do chamado "valor normal" estiverem relacionados com a eficiência dos produtores, mas, sim, naquelas promovidas por intervenções indevidas dos governos, casos para os quais a Organização, via GATT, autoriza aos países importadores a aplicação de contramedidas na forma de sobretaxas visando anular o fator predatório do preço do produto importado, trazendo-o à margem do multimencionado "valor normal". Tais valores acrescentados são conhecidos como direitos ou medidas antidumping.

Assim, no intuito de discorrer acerca dos direitos antidumping, cumpre, de pronto, afastar "a livre concorrência" como valor jurídico-econômico a ser tutelado, posto que este, na verdade, já se encontra acautelado, conforme se perceberá no que se segue.

Em economia, o estudo da concorrência parte de uma graduação em que a “concorrência perfeita" é tida como o máximo grau de atomização ${ }^{72}$ e pressupõe livre

\footnotetext{
${ }^{71}$ Jorge, 2015, p. 129.

${ }^{72} \mathrm{Um}$ mercado atomístico pressupõe um elevado número de produtores/vendedores sem que haja destaques dentre eles em razão da sua capacidade produtiva ou comercial. Cf. Silva, A. L. G. (2010). Concorrência sob
} 
circulação de produtos e meios produtivos do mercado, logo, uma meta inatingível ${ }^{73}$, mas que, ao ser perseguida, traz inúmeras vantagens especialmente para os consumidores, pois tende a lhes serem disponibilizados os melhores produtos possíveis pelos menores preços praticáveis.

Já o regime de concorrência imperfeita ou monopolística pressupõe um único produtor e o controle da circulação dos meios produtivos via barreiras à entrada e, por conseguinte, à circulação de mercadorias ${ }^{74}$, ou seja, o monopolista pode controlar o preço e a quantidade ofertada o que, consequentemente, anula os mecanismos de autocontrole do mercado $^{75}$.

Entre esses dois extremos teóricos, as economias reais buscam a chamada concorrência praticável ou "workable competition", trata-se, na verdade, de identificar os fatores que levariam a uma concorrência que fosse o mais próximo possível da dita "perfeita”. Deve ser perquirida via discretas intervenções estatais visando, em síntese, garantir um número suficientemente alto de agentes econômicos disputando o mercado, bem como alto grau de liberdade e grande volume de informação, tanto para os concorrentes, como para os consumidores, a fim de que se atinja certo equilíbrio otimizado na qualidade e no preço dos produtos ofertados ${ }^{76}$.

Destarte, o Direito Antitruste ou Direito da Concorrência visa combater as práticas anticoncorrenciais, de modo que tem a defesa da concorrência como bem jurídico a ser tutelado $^{77}$. A partir de tal constatação, afasta-se, desde já, a "livre concorrência" como valor jurídico a ser tutelado pela legislação antidumping, pois este já se encontra acautelado ${ }^{78}$.

condições oligopolísticas: Contribuições das análises centradas no grau de atomização/concentração dos mercados. Campinas, SP: Unicamp. (Coleção Teses), pp. 28-29.

73، A concorrência perfeita representa na ciência econômica o que o vácuo ou a ausência de atrito representam na física, isto é, situações teóricas cujo conhecimento revela-se necessário para melhor apreensão do que se passa na prática" (Nusdeo, F. (2015). Curso de economia: introdução ao direito econômico. 9. ed. São Paulo: Editora Revista dos Tribunais, p. 213).

${ }^{74}$ Silva, op. cit., p. 30.

${ }^{75}$ No jargão econômico essas situações são chamadas de falhas estruturais que, neste caso, vêm a derrubar todo o mecanismo de decisores e controladores do mercado. Cf. Nusdeo, op. cit., p. 122-123.

${ }^{76}$ Lima, R. A.; Magalhães, A. A. A. \& Sousa, S. P. (2017). As influências da teoria da "workable competiton" como forma mais eficaz de prática da concorrência na legislação brasileira. In: Revista da Defesa da Concorrência, vol. 5, n. 2. Brasília: CADE, pp. 230-231. Disponível em:

$<\underline{\text { http://revista.cade.gov.br/index.php/revistadedefesadaconcorrencia/article/view/342/176> }}$. Acesso em: 09 mar. 2018.

${ }^{77}$ Bensoussan, F. G. \& Gouvêa, M. F. (2016). Manual de Direito Econômico. 2. ed. Salvador: JusPodivm, pp. 643-644.

${ }^{78}$ Barral (2000, p. 36) alerta que parcela da doutrina jurídica parte de uma "visão simplista" e invoca a "livre concorrência" como fundamento da legislação antidumping, no entanto, explica que "a livre concorrência nem sempre é totalmente assegurada através da legislação antidumping. Ao contrário, o efeito imediato é o da 
Noutra senda, conforme já exposto, os chamados direitos ou medidas "antidumping" fazem parte dos "trade remedies" ou "medidas de defesa comercial" 79 que, por sua vez, são instrumentos de tutela da atividade produtiva de um país contra ameaças estrangeiras, visando preservar os agentes econômicos nacionais que tenham sua existência ameaçada pelo fato de não se encontrarem em condições de competir com os produtos ou serviços estrangeiros.

Em específico, consoante Jorge, os direitos antidumping são "barreiras não tributárias à importação de produtos do exterior e são utilizadas, de maneira discricionária pelo Estado, para proteger a indústria doméstica de eventuais danos causados por práticas desleais de comércio" $"$.

Aqui, vale retornar ao fato de que tais medidas somente são autorizadas para casos de dumping condenável, contudo, não são vinculativas, ou seja, uma vez constatada a ocorrência, a nação cuja atividade industrial estiver prejudicada ou ameaçada pode ou não aplicar os direitos antidumping, tratando-se, portanto, de medida discricionária.

Assim, os direitos antidumping não têm preocupação imediata com a otimização da concorrência ${ }^{81}$; seu objeto, na verdade, é remediar os efeitos de condutas de empresas que, mediante certas condições conferidas (ou não combatidas) pelos Estados de origem, acabam por prejudicar o surgimento, ou atrasar o desenvolvimento, do setor industrial dos mercados estrangeiros.

Em verdade, é preciso, mais uma vez, ter em mente que a aplicação de medidas antidumping pode, inclusive, causar prejuízo aos consumidores do país importador, na medida em que, por exemplo, pode inviabilizar indústrias ou varejistas nacionais receptoras do produto, tudo, em grande parte dos casos, para proteger agentes econômicos ineficientes, prejudicando, em última análise, o consumidor final.

Nesta seara, o AARU deixa claro que, mesmo após comprovada a situação de dumping condenável, os membros da OMC estão apenas autorizados a aplicar medidas antidumping, podendo não o fazer em nome do interesse público interno.

restrição da concorrência, já que reduz a capacidade competitiva das empresas estrangeiras, podendo inclusive levá-las a se retirarem do mercado".

${ }^{79}$ Segundo Bliacheriene (2007, p. 39) a defesa comercial "é o ramo do Direito Internacional Econômico que regula a utilização do subsídio das medidas de defesa comercial (antidumping, medidas compensatórias e medidas de salvaguarda) e o processo de investigação unilateral e multilateral".

${ }^{80}$ Jorge, 2015, p. 122.

${ }^{81}$ Neste ponto, cabe ressaltar que, em que pesem os legítimos interesses sociais envolvidos, os instrumentos de defesa comercial, entre eles as medidas antidumping, tendem, na verdade, a restringir a concorrência. 
1.3.3.2 Interesse público na aplicação dos direitos antidumping

Mediante a constatação de que a aplicação de medidas antidumping, ao impedir a importação de produtos com preços baixos, afeta diretamente a concorrência do país, podendo prejudicar toda uma cadeia de consumo, Cordovil coloca que é um "desafio saber dosar os efeitos negativos e efeitos positivos das medidas [antidumping] [...]" pois uma delas "pode salvar empregos na indústria doméstica, mas pode, por outro lado, levar ao desemprego milhares de pessoas na indústria consumidora $[\ldots] " 82$.

Desta forma, não é incomum que, da aplicação de medidas antidumping, se constatem maiores prejuízos à sociedade em geral, nomeadamente às indústrias receptoras e aos consumidores finais, em troca da subsistência de agentes econômicos por vezes economicamente ineficientes e inexpressivos.

Barral parte da constatação de que, ainda que o país importador comprove a ocorrência de dumping em determinada transação, inexiste no AARU a obrigação de aplicação de direitos antidumping e, além disso: "os critérios de aplicabilidade são pouco claros, e sua existência depende de direitos internos de cada Estado [...]”, de modo que “embora o princípio do interesse público, como norteadora e limitadora, de aplicação de medidas antidumping, não expressamente do AARU, normas correlatas vêm se materializado no direito interno dos Estados-Membros da $\mathrm{OMC}^{\prime 83}$.

Partindo da constatação, já aqui apontada, de que não se confundem os objetos da defesa da concorrência com o antidumping, Jorge acredita que "apesar da consideração de aspectos concorrenciais mínimos na avaliação do interesse público, deve-se sempre lembrar a verdadeira finalidade do antidumping, que é a defesa da indústria doméstica, devendo ele ser avaliado essencialmente dentro dessa perspectiva" 84

A partir dessa perspectiva, Jorge parte da realidade socioeconômica dos Países em Desenvolvimento e elabora seu raciocínio para defender que o real interesse público que deve ser resguardado quando da aplicação das medidas antidumping deve ser, nesses países, na verdade, o "bem-estar a longo prazo", ou seja, a "criação de um ambiente favorável ao

\footnotetext{
${ }^{82}$ Cordovil, L. A. G. (2009). O interesse público no antidumping. Tese (Doutoramento em Direito Econômico e Financeiro) - Universidade de São Paulo, São Paulo, p. 12. Disponível em:

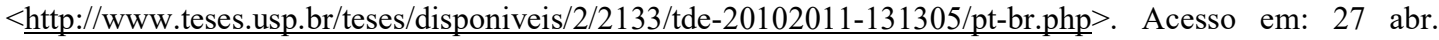
2018.

${ }^{83}$ Barral, 2000, p. 174

${ }^{84}$ Jorge, 2015, p. 172.
} 
desenvolvimento econômico, intelectual e social" de um país em busca do desenvolvimento, lógica pela qual, segundo o estudioso, em que pese algum prejuízo, geralmente temporário, a aplicação de direitos antidumping possa gerar ao nível concorrencial, a aplicação “adequada, visando à proteção seletiva e temporária (até ganhar competitividade internacional) de setores estratégicos [...], os benefícios dessas medidas não estarão restritos a determinados setores da indústria ou um grupo empresarial específico, mas irão abranger toda a sociedade [... ${ }^{\natural 85}$, ou seja, figurando como instrumentos de política desenvolvimentista.

\subsection{Dumping e os direitos antidumping como instrumento de política comercial ou política do protecionismo}

\subsubsection{O neoprotecionismo}

Com o advento do sistema multilateral de comércio, especialmente após a constituição da Organização Mundial do Comércio (OMC), deu-se grande abertura dos países via redução das barreiras tarifárias de modo a limitar a política industrial dos países membros da $\mathrm{OMC}$, beneficiando o processo de especialização do trabalho em âmbito mundial, de modo a, em tese, permitir que cada país tire o máximo proveito das suas vantagens comparativas e se mostrem extremamente competitivos em determinados setores.

Por isso, e por tudo o mais já exposto, em tese, os direitos antidumping deveriam ser medidas excepcionalíssimas, tanto pela lógica liberal, quanto pela complexidade técnicojurídica em determiná-lo. No entanto, persistem os discursos sobre a "injustiça" e a "deslealdade" nas relações comerciais, a compelir o uso do antidumping como mero instrumento de política protecionista com apelo populista.

Tal fenômeno é potencializado pelo fato de, no atual estágio da globalização, em especial nos países desenvolvidos, alguns setores da indústria tradicionais não conseguem competir com os novos players baseados nos países em desenvolvimento e pressionam seus governos visando bloquear a entrada desses produtos no mercado nacional.

Assim, não é incomum que países desenvolvidos usem as medidas antidumping para restringir o livre comércio como barreira não tarifária, visando dificultar e encarecer os

${ }^{85}$ Jorge, 2015, p. 173. 
produtos importados de modo a amparar agentes econômicos internos ineficientes - para tanto, se utilizam do que Porto chama de "argumento das indústrias senescentes", pelo qual se defende a utilização, por exemplo, de quotas e impostos alfandegários para proteger um setor que não se mostra mais competitivo, causando ineficiências na economia e procrastinando a implementação de necessárias "medidas de reconversão e reemprego" 86 .

Nessa perspectiva, Geraldello destaca o fato de os Estados Unidos e a União Europeia, conjuntamente, serem responsáveis por $53,2 \%$ dos casos em que a aplicação de medidas antidumping foram contestadas junto ao Órgão de Resolução de Conflitos (ORC), da $\mathrm{OMC}^{87}$. A autora ressalta ainda que:

[...] antes da constituição da OMC e nos primeiros anos do novo órgão (até o início dos anos 2000), os países desenvolvidos eram os principais demandantes de contestações. Isto pode ter ocorrido pelo receio dos países em desenvolvimento ou de menor desenvolvimento relativo de que o órgão fosse beneficiar os países desenvolvidos, como ocorria no antigo GATT.

E segue asseverando uma guinada nesse quadro a partir da reunião ministerial de Seattle em 1999, após a qual, nas suas palavras:

[...] as coalizões que se formaram no início dos anos 2000 entre os Estados em desenvolvimento e de menor desenvolvimento relativo para as negociações da Rodada de Doha e suas influências [...] quebraram o padrão anterior, [de modo que] a partir de 2001 - 02 os Estados em Desenvolvimento e de menor desenvolvimento relativo deixaram de ser os mais demandados e passaram a ser os que mais demandam nos processos abertos na $\mathrm{OMC}^{88}$.

Neste ponto, insta retornar ao fato de que, ronda após ronda de negociações do sistema GATT-OMC, cresce o apelo pela abertura comercial dos países via redução das barreiras tarifárias, de modo a melhorar o acesso aos mercados e a limitar a política industrial dos membros da $\mathrm{OMC}$, restando às medidas antidumping a condição de weapon choice $^{89}$ ou deus ex machina ${ }^{90}$, visando tirar proveito dos mercados alheios, porém, protegendo determinados setores do seu.

\footnotetext{
${ }^{86}$ Porto, 2017, p. 177.

${ }^{87}$ A autora acrescenta ainda que de tal percentual, "os EUA representam sozinhos $41,5 \%$ destas contestações" (Geraldello, 2015b, p. 23).

${ }^{88}$ Ibid.

${ }^{89}$ Expressão utilizada por Bastos (2012, p. 107).

${ }^{90}$ Expressão utilizada por Barral (2000, p. 45).
} 
Um dos estratagemas que até pouco tempo era largamente utilizado pelos Estados Unidos e, em menor escala, pela União Europeia para burlar o sistema multilateral de comércio por meio da aplicação de medidas antidumping é a metodologia de cálculo de margem de dumping conhecida como zeragem (ou zeroing).

Por zeragem, entende-se a prática de desconsiderar, computando como zero, as importações em que foi verificado que o preço do produto é mais baixo do que seu valor normal (também conhecido como dumping negativo), desconsiderando, por conseguinte, as transações em que não ocorre dumping e, por consequência, aumentando a probabilidade de ser apurado dumping, ocasionando um incremento no número de medidas antidumping impostas às importações.

Toda a polêmica em torno da zeragem, seguida das decisões da OMC, confirmaram que as regras dispostas no ARRU são rasas, obscuras e demasiadas flexíveis, permitindo o desvirtuamento do antidumping que abandonou seu propósito inicial e passou a ser mero instrumento de política comercial ou política do protecionismo.

Destarte, a rodada de Doha, lançada no final de 2001, destacou a revisão do Acordo Antidumping como tema da agenda de negociações, assuntos em torno do qual as nações se dividiram em dois grupos: de um lado os EUA e a UE que não advogam a necessidade de se alterarem as regras existentes; do lado oposto se estabeleceu o chamado friends of antidumping, composto por cerca de 20 países, dentre os quais Brasil, Chile, Colômbia, Costa Rica, Hong Kong, China, Israel, Japão, Coreia, México, Noruega, Singapura, Suíça, Tailândia e Turquia, que defendem o aperfeiçoamento das normas visando torná-las mais acuradas, de modo a restringir o uso das medidas antidumping, via malabarismos burocráticos, para outros fins que não os originais ${ }^{91}$. Nesse interesse, deu-se a criação de um grupo ad hoc com a finalidade de captação e apreciação de propostas voltadas ao aperfeiçoamento dos procedimentos de investigações antidumping, dentre as quais destacam-se a proibição da zeragem; no entanto, somente em fevereiro de 2012, após acordos entre os Estados Unidos, a União Europeia e o Japão em relação a seus conflitos sobre zeragem, os estadunidenses deixaram de usá-lo nas revisões administrativas.

No que tange ao histórico da zeragem no âmbito da $\mathrm{OMC}$, novamente destaca-se o acurado relato de Geraldello que aponta os EUA e a UE como os únicos contestados sobre

\footnotetext{
${ }^{91}$ Thorstensen, V. \& Jank, M. S. O Brasil e os Grandes Temas do Comércio Internacional. São Paulo: Aduaneiras, 2005 apud Ferreira, 2009.
} 
a prática do método, com a ressalva de que a mesma foi abandonada pela Europa no início dos anos 2000 após “derrotas nos casos EC-Bed Linen para a Índia (DS141, 1998) e ECPipe FItting para o Brasil (DS219, em 2000)"92, passando da condição de demandada, pelos países em desenvolvimento, para a de demandante, em desfavor dos Estados Unidos que, por sua vez, fora condenado pela ORC em todos os casos em que fora apontado o uso da zeragem na determinação do dumping, até que:

[...] em dezembro de 2006, os Estados Unidos proibiram o uso do zeroing nas novas investigações iniciais de margens de dumping, permitindo a prática nas outras fases [...], tentando evitar a retaliação por parte da União Europeia, Japão e outros parceiros comerciais, [no entanto, a autora destaca] a pressão que o país norte americano tem feito por uma legalização explícita da metodologia do zeroing nas negociações da Rodada Doha, conquanto afirme que o Acordo Antidumping já permita essa prática (US Commerce Department..., 2011) ${ }^{93}$.

\subsubsection{As medidas antidumping como estratégia desenvolvimentista}

Tomando por base a escorreita digressão histórica de Há-Joon Chang ${ }^{94}$, Jorge constata que a maioria dos países atualmente desenvolvidos:

[...] adotou em seu período de catching up, políticas protecionistas, visando beneficiar sua indústria doméstica por meio, principalmente, da proteção tarifária, passando a defender a liberalização comercial apenas após atingido competitividade internacional. [Dessa forma] da Grã-Bretanha (século XVIII), passando por EUA (século XIX), Alemanha (século XX), até chegar ao Japão e os NIP, observa-se a opção pelo protecionismo e a proteção da indústria, especialmente, com a utilização de proteção tarifária ${ }^{95}$.

\footnotetext{
${ }^{92}$ Geraldello, C. S. (2015a). Antidumping na OMC. In: Medidas antidumping e política doméstica: o caso da citricultura estadunidense [online]. São Paulo: Cultura Acadêmica, p. 60. Disponível em: $<$ https://repositorio.unesp.br/bitstream/handle/11449/138597/ISBN9788579836657.pdf?sequence=1\&isAllo wed $=\mathrm{y}>$. Acesso em: 23 abr. 2018.

${ }^{93}$ Ibid., p. 62. A autora segue seu relato ao afirmar que "No entanto, a OMC e a União Europeia mostraram-se céticas quanto ao pleno cumprimento dessa medida pelos Estados Unidos, pois a proposta não chega a prever danos ou outros tipos de compensação e apenas serviria para os casos futuros (US Commerce Department..., 2011). Além do mais, a nova determinação do Departamento de Comércio deixa uma margem de manobra para a possível utilização do zeroing, ao permitir a aplicação de método de comparação diferente e mais apropriado para as reviews [revisões], sem esclarecer qual seria esse método, nem quando seria apropriado usá-lo".

${ }^{94}$ Ghang, Há-Joon. (2004). Chutando a Escada: a estratégia do desenvolvimento em perspectiva histórica. Tradução de Luiz Antônio Oliveira de Araújo. São Paulo: UNESP, 2004. apud Jorge, 2015.

${ }^{95}$ Ibid., pp. 173-181.
} 
$\mathrm{O}$ autor segue argumentando que a crescente liberalização do comércio internacional via o multilateralismo, capitaneado pelo sistema GATT - OMC, tem por consequência negar aos países em desenvolvimento o acesso aos mesmos meios ou estratégias que os países atualmente desenvolvidos fizeram uso para alcançar o atual estágio socioeconômico ou, pela expressão cunhada por Chang, o sistema atualmente posto acaba por "chutar para fora" 96 a escada utilizada pelos países que se encontram no topo da economia mundial, negando o acesso aos demais ${ }^{97}$.

À vista disso, ao constranger os PED a adotarem uma política tarifária praticamente neutra em relação aos países desenvolvidos, o atual sistema multilateral de comércio os obriga a procurar alternativas, o que alça os direitos antidumping, por todas as peculiaridades já aqui apresentadas, à condição de raro instrumento de política desenvolvimentista à disposição dos países que ainda não detêm competitividade em setores estratégicos como, por exemplo, a indústria de alta tecnologia e a de defesa.

\subsection{Mais dumping ou menos dumping?}

A partir do exposto, percebe-se claramente que o dumping e os direitos antidumping encontram na política o seu papel mais preponderante: o de instrumento à disposição do neoprotecionismo ou de estratégia desenvolvimentista. Tal se dá via quebra das regras internacionalmente postas para satisfação de interesses que sequer podem ser chamados de "nacionais", posto que, na maioria dos casos, tratam-se de interesses de agentes econômicos ineficientes, que atentam contra a lógica na qual se apoiam as teorias livre-cambista e da concorrência, gerando prejuízos para os próprios nacionais, sejam eles agentes econômicos

\footnotetext{
${ }^{96}$ Ghang, 2004 apud Jorge, 2015.

${ }^{97}$ Neste ponto, é preciso dar espaço para posicionamentos como o de Cunha quando diz que: “a OMC não é uma agência para o desenvolvimento, ou seja, não é uma instituição adequada, nos planos de regulação e institucional, para especificamente (e privilegiadamente) apoiar e facilitar o desenvolvimento económico dos países em desenvolvimento. O seu objetivo principal é o de criar e manter um sistema comercial multilateral duradouro, integrado e viável. Todavia, deve notar-se que no preâmbulo do acordo que institui a OMC se reconhece que é necessário envidar esforços positivos no sentido de assegurar que países em desenvolvimento e em particular os PMA beneficiem de uma parte do crescimento do comércio internacional que corresponde às suas necessidades de desenvolvimento econômico" (Cunha, L. P. (2014). O fracasso do Doha Round e a questão do desenvolvimento. In: Boletim de Ciências Económicas da Faculdade de Direito da Universidade de Coimbra, vol. LVII, Tomo I, Coimbra).
} 
que acabam por carecer de insumos a custos justos ou o consumidor final que arca com os custos ao consumir um produto mais caro e com menor qualidade ${ }^{98}$.

${ }^{98}$ Segundo Porto (2017, p. 535): "a experiência bem conhecida das últimas décadas, mesmo dos dois últimos séculos, é por seu turno muito clara mostrando os resultados muito melhores conseguidos com políticas de abertura comercial, quando comparadas com os resultados verificados com políticas protecionistas." 


\section{O DISCURSO DO DUMPING SOCIAL}

\subsection{Sobre discursos polarizadores}

Consoante Bunescu, logo após a unificação, a Alemanha implementou uma ambiciosa política de equalização de salários e padrões sociais visando a rápida equiparação dos standards orientais aos ocidentais. Posto isso, os custos salariais por hora na manufatura da antiga Alemanha Oriental saltaram de 7\% para mais de 70\% do nível ocidental em apenas cinco anos, de maneira que essa política teve por resultado uma perda de competitividade que destruiu quase $80 \%$ dos empregos na indústria e migração para o Oeste de cerca de $10 \%$ da população oriental. A má interpretação da sua realidade e a consequente má alocação dos fatores produtivos custou aos alemães uma enorme perda de produção, só estancada mediante vultosas transferências governamentais aos novos Länders ${ }^{99}$.

Em estudo sobre a intersecção entre política e comunicação, Ruud Koopmans parte do mesmo cenário, a reunificação alemã após 1989, e expõe os fatos que ficaram conhecidos como os "motins de Hoyerswerda", cidade localizada na antiga porção oriental, ocorridos em setembro de 1991, quando a população local se voltou contra os estrangeiros que, na época, eram cerca de 200 numa população de 70.000 habitantes $^{100}$.

O estudioso narra que os eventos se iniciaram numa praça da cidade com um ataque de um grupo de skinheads de direita a vendedores de rua de origem vietnamita que se seguiu de um ataque noturno contra um edifício onde viviam alguns desses vietnamitas juntamente com um grupo de trabalhadores originários de Moçambique. Após quatro noites de agressões, que envolviam atirar pedras e gritar abusos racistas, e quando os skinheads já se faziam acompanhar por jovens locais sem vínculos com a direita e de um número crescente de cidadãos locais a assistir e a aplaudir os agressores, a polícia local finalmente reforçou a segurança em volta do prédio de morada dos trabalhadores ${ }^{101}$.

\footnotetext{
${ }^{99}$ Bunescu, L. M. (2011). The allegation of social dumping: a case study on Romania. Centre international de formation européenne, Institut Européen des Hautes Etudes Internationales. Disponível em: <https://www.ieei.eu/IE-EI/Ressources/file/memoires/2011/LBunescu.pdf $>$. Acesso em: 05 dez. 2018, p. 23.

${ }^{100}$ Koopmans, R. (2004). Movements and Media: Selection Processes and Evolutionary Dynamics in the Public Sphere. In: Theory and Society, 33: 367-391. Disponível em:

$<$ https://pdfs.semanticscholar.org/2fb3/ef9bba6688664170f17f3c85c05910292bf8.pdf $>$. Acesso em: 22 nov. 2018.

${ }^{101}$ Ibid.
} 
Na sequência, os manifestantes se voltaram para uma casa em uma parte diferente da cidade onde residiam algumas dezenas de requerentes de asilo. Só neste momento é que foi despertada a atenção da mídia nacional que, ignorando os fatos iniciais, ou seja, a xenofobia contra os vietnamitas, descreveu o movimento como um tumulto anti-asilo e, na sequência, políticos nacionais e locais de todas as inclinações emitiram declarações e realizaram coletivas de imprensa, assumindo suas opiniões sobre as políticas de asilo ${ }^{102}$.

Os eventos em si terminaram depois de seis dias com a evacuação amplamente divulgada pelas autoridades do que sumariamente chamavam de "requerentes de asilo" (embora a grande maioria deles não fosse) da cidade, contudo, o debate sobre asilo durou por mais dois anos e foi, de acordo com pesquisas e à despeito do massivo desemprego e outras dificuldades relacionadas ao processo de reunificação, encarado pelos alemães como sendo o problema mais importante que o país enfrentava até o final de junho de 1993, quando a controvérsia foi finalmente encerrada por uma mudança na Constituição que, por sua vez, limitou fortemente os direitos dos requerentes de asilo ${ }^{103}$.

A teoria de Koopmans tenta provar que "mensagens polarizadoras sempre têm legitimidade questionável"; para tanto, o autor explica que a polarização política se estrutura sobre três conceitos: legitimidade, ressonância e visibilidade ${ }^{104}$.

Assim, legitimidade é a capacidade que uma mensagem tem de gerar consenso, contudo, o estudioso alerta para o fato de que uma mensagem legítima não é necessariamente correta - o ponto a considerar para avaliar a legitimidade de uma mensagem é, para Koopmans, seu nível de aceitação e concordância dentre os receptores ${ }^{105}$.

Ressonância, por sua vez, é a capacidade de determinada mensagem (discurso) de gerar discussão a respeito de si mesma. Aqui, a teoria de Koopmans afirma que a ressonância gera visibilidade ${ }^{106}$.

Visibilidade, por sua vez, é a extensão da cobertura dos meios de comunicação de massa; para Koopmans, questões polêmicas, ou seja, sem legitimidade, sempre têm vantagem na disputa por espaço na mídia ${ }^{107}$.

\footnotetext{
${ }^{102}$ Koopmans, p. 380-383.

${ }^{103}$ Ibid., p. $371-377$.

${ }^{104}$ Ibid.

${ }^{105}$ Ibid.

${ }^{106}$ Ibid., loc. cit.

${ }^{107}$ Ibid.
} 
Nessa perspectiva, Koopmans defende que discursos polarizadores carecem de legitimidade, mas ganham em ressonância e, por conseguinte, em visibilidade ${ }^{108}$.

Em arremate, essa sequência de má leitura da realidade, falta de empatia a estrangeiros, discursos polarizadores e proposições legislativas equivocadas também estão na base de toda a discursão sobre dumping social, em especial, mas não somente, dos fatos que culminaram com a proposta da "cláusula social" no âmbito do subsistema multilateral de comércio e das propostas de diretivas europeias diante da famigerada "fobia ao canalizador polonês" no caso da prestação de serviços transfronteiriços no domínio do subsistema regional de comércio.

\subsection{O discurso do dumping social no subsistema multilateral de comércio}

\subsubsection{A legítima demanda por trabalho digno na economia global}

Em 1919, por meio do Tratado de Versalhes, criou-se Organização Internacional do Trabalho (OIT), visando "estabelecer padrões internacionais mínimos para as relações trabalhistas e garantir melhores condições de trabalho em todo o mundo, com vistas a promover a dignidade humana, o bem-estar geral e a justiça social [...]"109.

Desse modo, o Direito Internacional do Trabalho é o ramo do Direito Internacional Público que "visa a estabelecer padrões internacionais mínimos de relações trabalhistas, com o intuito de promover a dignidade humana em todo o mundo, o maior bem-estar da humanidade e a justiça social, colaborando, assim, para a paz"110.

Desde então, a OIT vem protagonizando o processo de normatização internacional do trabalho, cuidando não só da construção, mas também da efetivação, junto aos Estadosmembros, dos inúmeros avanços jus laborais construídos de modo tripartite, ou seja, com a participação de representantes dos empregadores, dos empregados e Estados.

$\mathrm{Na}$ qualidade de órgão jurígeno internacional, os principais instrumentos utilizados pela OIT são: Convenções e Recomendações. As primeiras "são objeto de ratificação pelos

\footnotetext{
${ }^{108}$ Koopmans, p. 380-383.

${ }^{109}$ Portela, 2016, p. 466

${ }^{110}$ Ibid., p. 464.
} 
Estados-membros, configurando-se como típicos tratados internacionais juridicamente cogentes"111, ou seja, são normas do tipo hard law. Já as Recomendações

[...] são atos normativos que têm importante função como fonte do direito do trabalho, na medida em que servem de princípios diretores e modelos normativos [...] mas não são objetos de ratificação [...] não têm natureza jurídica de tratado internacional. Não se revestem, pois, de caráter obrigatório [...], muita das vezes elas são adotadas no sentido de complementar uma convenção, proporcionando diretrizes mais precisas de como esta pode ser aplicada ${ }^{112}$.

Assim, desempenham papel que as tipificam como soft law.

Em complemento a esses instrumentos normativos, a OIT ainda faz uso das resoluções e dos protocolos. São fontes de direito de cunho hermenêutico, sendo as primeiras destinadas ao preenchimento de lacunas jurídicas que eventualmente dificultem a implementação de convenções e recomendações, restando aos protocolos a função de atualizar as convenções e servir de vetor de adaptação a novas realidades.

Em arremate, o sistema normativo que promove a interação da hard law (convenções) com normas de soft law (recomendações) implica na construção de um direito bastante inovador, com alto grau de propagação, tanto é que essa organização internacional já conta com 187 Estados-membros e, desde sua fundação, deram-se 8.123 ratificações e 400 instrumentos adotados, sendo 189 convenções, 205 recomendações e 6 protocolos ${ }^{113}$.

Porém, "por se tratar de normas de caráter universal, destinadas a terem vigência internacional, os instrumentos normativos produzidos pela OIT são bastante genéricos"114, fazendo, geralmente, uso de cláusulas de flexibilização “que permitem ao país fixar provisoriamente normas menos rígidas do que as previstas, de excluir algumas categorias de trabalhadores da aplicação de uma convenção ou de aplicar certas partes de uma norma internacional" 115 .

Isto posto, o sistema de controle de normas da OIT se dá por meio da análise de relatórios periódicos enviados pelos próprios Estados-membros (controle regular) ou via

\footnotetext{
${ }^{111}$ Meireles, G. F. (2016). Trabalho, comércio e dignidade no Direito Internacional contemporâneo. Curitiba: Juruá, p. 178.

${ }^{112}$ Ibid.

${ }^{113}$ International Labor Organization. (1996-2017). Normlex: Information System on International Labour Standards. [on-line]. Disponível em: <https://www.ilo.org/dyn/normlex/en/f?p=NORMLEXPUB:1:0::NO>. Acesso em: 26 jul. 2018.

${ }^{114}$ Meireles, op. cit., p. 182.

${ }^{115}$ Ibid.
} 
apreciação de "reclamação" ou "queixa" apresentada por um Estado-membro, organização representante de trabalhadores ou empregadores ou ainda pelo Conselho de Administração da própria organização (controle provocado).

De forma geral, as sanções aplicadas pela OIT são de natureza política se operacionalizadas por meio de "exposição do caso para a comunidade com vistas a pressionar o Estado que descumpre as normas do sistema a dar-lhes efetividade" 116 , sistemática que vem sendo alvo de críticas por carecer de "força executiva"117.

A partir disso, alguns autores chegam a não conferir a essa "exposição vexatória" um caráter sancionatório, o que limitaria o sistema de promoção de direitos fundamentais da OIT a uma mera "supervisão internacional"118; outros afirmam que "a OIT não possui um mecanismo coercitivo"119 ou "poder punitivo"120, fato que configura "um fator limitante à eficácia dos direitos trabalhistas em âmbito internacional"121.

À despeito de todo o esforço da OIT, fato é que a clássica oposição entre capital e trabalho ganha novos contornos com a contemporânea internacionalização da economia e a incitação ao livre comércio. A queda do muro de Berlim, em um passado já não tão recente, possibilita que o capitalismo avance a uma fase marcada pela competitividade crescente, mobilidade de capital, acelerada evolução tecnológica, nomeadamente nos processos produtivos, culminando em uma aparente incompatibilização entre os interesses do mercado e a consecução dos direitos dos trabalhadores.

Dessa forma, a expansão ao estrangeiro das atividades das empresas passou a ser regra de sobrevivência; além disso, as novas tecnologias de informação e os avanços na superação das barreiras ao comércio internacional ${ }^{122}$, bem como as novas facilidades no que

\footnotetext{
${ }^{116}$ Meireles, 2016, p. 195.

${ }^{117}$ Ibid., p. 212.

${ }^{118}$ Gomes, A. V. \& Bezerra, L. P. Questionamentos acerca da construção doutrinária e jusrisprudencial do dumping social: do Direito do Comércio Internacional ao Direito do Trabalho Brasileiro. In: Dutra, L. P. B. (2016). Dumping social no direito do trabalho e no direito econômico. Curitiba: Juruá, p. 73.

${ }^{119}$ Casagrande, L. P. \& Antunes, T. C. M. O dumping social no âmbito internacional e a adoção do seu conceito no direito interno. In: Dutra, L. P. B. (2016). Dumping social no direito do trabalho e no direito econômico. Curitiba: Juruá, p. 123.

${ }^{120}$ Ibid., p. 127.

${ }^{121}$ Ibid.

${ }^{122}$ Numa abordagem atenta ao comércio mundial, Cunha (2003, pp. 257-258) atrela a ideia de globalização às "crescentes interdependências das economias" mundiais, sendo "predominantemente conduzida por forças microeconómicas", contudo, "promovida e reforçada por políticas orientadas para o mercado desenvolvidas desde os anos 80", destacando como causas do fenômeno "a diminuição dos custos de transporte e de comunicação; os progressos livre-cambistas; a desregulação dos mercados; uma maior liberdade na circulação dos capitais; a integração de regiões como a Europa Central e Oriental e a China na economia mundial, com as respectivas consequências na divisão internacional do trabalho" e, por fim, aponta "alterações no padrão de
} 
tange à mobilidade das pessoas e processos produtivos, fazem surgir uma nova dinâmica na economia mundial em que a inovação e a necessidade de cortar custos não são opções, mas questões de sobrevivência. Nessa esteira, grandes, médias e pequenas empresas disputam um único mercado, o global ${ }^{123}$ e, por conseguinte, os atores econômicos, na contemporaneidade, se veem compelidos a buscar alocar suas plantas produtivas em países que lhe oferecem "melhores" condições.

Desta feita, apesar da imensa mobilização da OIT, fato é que, ainda hoje, grandes corporações transnacionais e alguns Estados negligenciam os standards sociolaborais que derivam diretamente da consagração dos Direitos Humanos, da noção de Dignidade da Pessoa Humana, nomeadamente dos direitos universalmente reconhecidos ao trabalho digno, à integridade física e moral e, também, à remuneração justa.

Em breve amostragem, por exemplo, em abril de 2013, houve o colapso do edifício Rana Plaza em Dhaka, Bangladesh, que abrigava fábricas de roupa independentes que forneciam peças para marcas como o Grupo Benetton, Mango, Wal-Mart, The Children's Place, Primark, Monsoon, DressBarn, H\&M e outras ${ }^{124}$, matou pelo menos 1.132 pessoas e feriu mais de 2.500. Cinco meses antes, pelo menos 112 trabalhadores perderam a vida em

vantagens comparativas; intensificação da concorrência internacional [...]; percepção de uma crescente interdependência entre economias; redução de autonomia, em cada Estado, na condução da política económica (em particular macroeconómica, v. g. cambial e financeira)".

${ }^{123}$ Para Faria, "globalização é um conceito relacionado às ideias de "compressão" de tempo e espaço, de comunicação em tempo real, on-line, de dissolução de fronteiras geográficas, de multilateralismo políticoadministrativo e de policentrismo decisório". O autor destaca ainda o caráter polissêmico da globalização, posto que, na verdade, tal ideia é resultante de uma série de fenômenos verificados nos mais diversos campos do conhecimento. (1) Em economia: o "aumento do intercâmbio comercial em mercados intercruzados"; a internacionalização do sistema financeiro; o surgimento de novos produtos "descolados" do sistema produtivo; a universalização e acirramento da concorrência em escala planetária; consolidação de um sistema de corporações mundiais; a mobilidade quase ilimitada alcançada pela circulação dos capitais". (2) No "plano institucional": "a dificuldade do sistema político-legislativo convencional de estabelecer regras do jogo estáveis e coerentes e o esgotamento da idéia de hierarquia como princípio ordenador da vida social; a crescente porosidade na linha de demarcação entre o Estado e a sociedade; e, por fim, o esvaziamento da ideia de território como fundamento e objeto do Estado, [...], uma vez que as atividades sociais e financeiras passam a depender de pessoas, coisas e ações dispersas pelos cinco continentes." (3) No "plano político": "rompe-se a aliança histórica entre Estado Nacional, sistema econômico e democracia representativa. Na medida em que a globalização, conduz à interdependência, estimula a formações de blocos regionais [...] e também cria novas dinâmicas intra e inter-regionais, estimulando com isso a expansão de formas de coordenação política nãohierárquica e com geometria variáveis" (Faria, J. E. (2010). Sociologia Jurídica: direito e conjuntura. 2. ed. São Paulo: Saraiva. [versão eletrónica]).

${ }^{124}$ USA Today. (2013). Toll in Bangladesh building collapse climbs to 275. [on-line]. Disponível em: $<$ https://eu.usatoday.com/story/news/world/2013/04/24/bangladesh-building-collapse/2108727/>. Acesso em: 22 jul. 2018. 
outro trágico acidente, presos dentro da fábrica de Tazreen Fashions, fornecedora da C\&A ${ }^{125}$, nos arredores de Dhaka ${ }^{126}$.

Outros casos que chamam atenção envolvem o Foxconn Technology Group ${ }^{127}$, gigante da indústria de eletrônicos que emprega mais de 1.2 milhões de pessoas em suas plantas de manufatura na Ásia, Europa, América do Sul e Norte, e é a principal fornecedora de empresas como a Apple, Amazon, Cisco, Dell, Google, HP, Microsoft, Motorola, Nintendo, Nokia, Sony e Toshiba, etc. ${ }^{128}$. Os casos envolvem trabalho infantil ${ }^{129}$, péssimas condições de alojamento ${ }^{130}$ e mortes por suicídios ${ }^{131}$ em protestos ${ }^{132}$, em decorrência de jornadas laborais que vão de 12 a até 32 horas seguidas ${ }^{133}$ e acidentes na linha de montagem ${ }^{134}$.

Diante da ínfima amostragem acima carreada, afasta-se, de pronto, qualquer alegação de que o presente texto se presta a empunhar a bandeira de um "laissez faire social"135, posto que é inegável a necessidade de regulamentação internacional visando garantir a observância de padrões sociais mínimos, especialmente no que diz respeito a garantia da segurança e dignidade dos trabalhadores em todo o planeta; no entanto, tal

\footnotetext{
${ }^{125}$ The Guardian. (2013). Bangladesh textile factory fire leaves more than 100 dead. [on-line]. Disponível em: $<$ https://www.theguardian.com/world/2012/nov/25/bangladesh-textile-factory-fire> . Acesso em: 22 jul. 2018. ${ }^{126}$ International Labor Organization. (1996-2017). The Rana Plaza Accident and its aftermath. [on-line]. $<$ http://www.ilo.org/global/topics/geip/WCMS 614394/lang--en/index.htm>. Acesso em: 22 jul. 2018.

${ }^{127}$ Sediada em Taiwan, é atualmente a maior empresa de terceirização de eletrônicos do mundo e a maior empregadora de chineses no setor privado, contando com 1,2 milhões de trabalhadores. Cf. Hon Hai/Foxconn Technology Group. [on-line]. Disponível em:

$<$ http://www.foxconn.com/GroupProfile_En/GroupProfile.html $>$. Acesso em: 23 jul. 2018;

ProPublica. (2012). By the Numbers: Life and Death at Foxconn. [on-line]. Disponível em:

$<$ https://www.propublica.org/article/by-the-numbers-life-and-death-at-foxconn $>$. Acesso em: 23 jul. 2018.

${ }^{128}$ Nunes, M. F. The impact of negative social/environmental events on the market value of supply chain partners. (2015). Dissertação (Mestrado). Fundação Getúlio Vargas - Escola de Administração de Empresas de São Paulo, São Paulo, 184p., pp. 75-76. Disponível em:

$<$ https://bibliotecadigital.fgv.br/dspace/bitstream/handle/10438/15045/Masters\%20Dissertation.MFN2016.Jan\%20-\%20v.final.protocolo2.pdf $>$. Acesso em: 23 jul. 2018.

${ }^{129} \mathrm{Em} 2010$, auditores da Apple apontaram 91 casos de trabalho de menores trabalhando ilegalmente nas linhas de montagem de iphones e ipads. Cf. Duhigg, C. \& Barboza, D. (2012). In China, Human Costs Are Built Into an iPad. New York Times. [on-line]. Disponível em:

$<$ https://www.nytimes.com/2012/01/26/business/ieconomy-apples-ipad-and-the-human-costs-for-workers-inchina.html?ref=global-home\&pagewanted=all $>$. Acesso em: 23 jul. 2018; Johnson, J. (2011). 1 Million Workers. 90 Million iPhones. 17 Suicides. Who's to Blame? Wired. [on-line]. Disponível em: $<$ https://www.wired.com/2011/02/ff joelinchina/all/1/>. Acesso em: 23 jul. 2018; Nunes, op. cit., loc. cit.

${ }^{130}$ Duhigg \& Barboza, op. cit.

${ }^{131}$ Johnson, op. cit.

${ }^{132}$ Ibid.

${ }^{133}$ Barboza, D. (2010). A Night at the Electronics Factory. New York Times. [on-line]. Disponível em: <https://www.nytimes.com/2010/06/20/weekinreview/20barboza.html?ref=foxconntechnology $>$. Acesso em: 23 jul. 2018.

${ }^{134}$ Nunes, op. cit., loc. cit.

${ }^{135}$ Moreira, 2014, p. 45.
} 
imperativo não se deve a uma alegada justeza sobre a concorrência entre empresas e Estados, mas, em absoluto, para garantir a necessária efetividade dos direitos e garantias sobre integridade e dignidade dos trabalhadores em todo o mundo.

\subsubsection{Globalização, desenvolvimento econômico e interdependência}

Almeida, ao abordar a Teoria do Crescimento Econômico, trata logo de distinguir os conceitos de “crescimento' e "desenvolvimento" econômico, quando assevera que "o crescimento econômico é o crescimento contínuo da renda per capta a longo prazo" enquanto que:

[...] desenvolvimento econômico é um conceito mais qualitativo, incluindo as alterações da composição do produto e a alocação dos recursos pelos diferentes setores da economia, de forma a melhorar os indicadores de bem-estar econômico e social (pobreza, desemprego, desigualdade, condições de saúde, alimentação, educação e moradia $)^{136}$.

Neste âmbito, Nusdeo aponta como fatores essenciais ao processo de desenvolvimento econômico a "acumulação de capital, a evolução tecnológica e a disponibilidade de mercado consumidor" e, na sequência, lista as principais políticas que um país pode dispor para este fim como sendo a "política creditícia, a política monetária a adaptação institucional”"137.

No que tange ao papel do fenômeno da globalização econômica no processo de crescimento e/ou desenvolvimento econômico, não existe consenso; para parte dos estudiosos trata-se de uma oportunidade, ao passo que, outros, ao contrário, afirmam que a globalização, em especial no tocante à "liberalização do comércio internacional" e ao "desenvolvimento do sistema multilateral de comércio", servem a um propósito ou a uma “estratégia idealizado e praticada pelos País Atualmente Desenvolvidos - PAD em vistas à manutenção da sua hegemonia política e econômica em detrimentos dos demais, especialmente dos Países em Desenvolvimento - PED"138.

\footnotetext{
${ }^{136}$ Almeida, L. C. B. (2012). Introdução ao direito econômico: direito da economia, direito econômico, law and economics, análise econômica do direito, direito econômico internacional. 4. ed. São Paulo: Saraiva, p. 293-294.

${ }^{137}$ Nusdeo, 2015, pp. 292-293.

${ }^{138}$ Jorge, 2015, p. 31.
} 
Para os primeiros, a globalização, se bem aproveitada, é benéfica para os países ricos, excelente para os pobres que procuram integrar-se ao comércio internacional e danosa aos países que ficam à margem do sistema, presos a ideias políticas ultrapassadas ou vítimas da própria incapacidade de gerir seus melhores recursos naturais e intelectuais. Trata-se de pensamento segundo o qual a globalização é, na verdade, uma "janela de oportunidades" para acelerar o processo de aumento de riqueza das nações e beneficiar as populações que nelas vivem ${ }^{139}$. Para reforçar este argumento, os defensores da globalização contam com instituições como o Banco Mundial que, por exemplo, divulgou um estudo conforme o qual países pobres mais globalizados apresentam crescimento médio em PNB per capita de 5\% ao ano, nos anos 1990; para os países industrializados, essa média não ultrapassou 2\%; e para os países pobres menos industrializados, o recuo foi de $-1 \%$; no início do século XXI, dezenas de países cujas economias ainda são subdesenvolvidas aceleram o ritmo de crescimento: a Índia, com uma média de $7 \%$ ao ano, e a China, com 10\%, também em média $^{140}$.

Noutra senda, estão os defensores da tese de que a globalização e o consequente multilateralismo no comércio internacional são, na verdade, instrumentos idealizados e montados pelos países hegemônicos para "chutar a escada"141, conforme Jorge, "impedindo as nações em desenvolvimento de adotarem as políticas e instituições que eles próprios adotaram $[. .$.$] quando se achavam em processo de desenvolvimento"142.$

\footnotetext{
${ }^{139}$ Cretella Neto, J. (2012). Curso de direito internacional econômico. São Paulo: Saraiva, pp. 388-389.

${ }^{140}$ The World Bank. (2001). Globalization, Growth and Poverty: building an inclusive world economy. [online]. Disponível em: <http://documents.worldbank.org/curated/en/954071468778196576/Globalizationgrowth-and-poverty-building-an-inclusive-world-economy>. Acesso em: 02 mar. 2018. Porto (2017, p. 34) destaca ainda o chamado "período de ouro" que vai de 1950 até 1973 - impulsionado pelas instituições de Bretton Woods, o mundo experimentou um enorme avanço no comércio internacional que resultou numa taxa anual de crescimento das exportações de 7,88\%, acompanhada do crescimento dos PIB's per capita de 2,93\%". ${ }^{141} \mathrm{Em}$ Kicking away the ladder: development strategy in historical perspective, livro do coreano Ha-Joon Chang, economista e professor da Universidade de Cambridge, lançado em 2002, o autor parte de uma "análise do desenvolvimento econômico sob um prisma histórico" para demonstrar que "os países desenvolvidos tivessem mesmo adotado as políticas que recomendam aos países em desenvolvimento, não seriam o que são hoje. Muitos deles, ao longo de sua trajetória de desenvolvimento, recorreram a políticas comerciais e industriais protecionistas, atualmente consideradas políticas "ruins", de modo que "os países desenvolvidos, pregando políticas ortodoxas, estariam hoje 'chutando a escada' para que os países em desenvolvimento não consigam seguir os mesmos caminhos trilhados por eles para se desenvolver" (Varela, C. A. (2006). Chutando a Escada: a estratégia do desenvolvimento em perspectiva histórica. Rev. Econ. Polit. [on-line], vol. 26, n. 4, pp. 627-628. Disponível em:

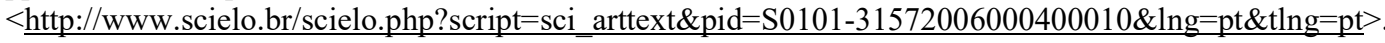
Acesso em: 22 abr. 2018).

${ }^{142}$ Jorge, 2015, pp. 39-40.
} 
À despeito da polêmica, fato é que uma "ideia-chave" para se compreender a "reestruturação do capitalismo" provocada pela globalização é o chamado "processo de destruição criadora" que leva "a substituições cada vez mais rápidas na gama de bens e serviços existentes", que "obriga as empresas a produzir bens e prestar serviços em qualquer parte do mundo" e na "possibilidade de fragmentar ou distribuir internacionalmente as diferentes etapas produtivas, com o objetivo de reduzir os custos totais da produção"143. Para tanto, os agentes econômicos passam a:

[...] pressionar os governos para reduzir barreiras protecionistas, remover obstáculos alfandegários, estimular o intercâmbio tecnológico, uniformizar padrões contábeis, societários e legais, desenvolver novos mecanismos de solução de controvérsias e redesenhar os papeis do Estado, atribuindo-lhe como prioridade a garantia da estabilidade da ordem jurídica e a facilitação do funcionamento dos mercados ${ }^{144}$.

Ainda no âmbito desta "transformação na organização internacional da produção" 145 , Porto destaca o avanço do comércio intra-setorial impulsionado por

[...] um acesso mais fácil a inovações e melhorias tecnológicas, uma melhoria geral da qualificação das pessoas e naturalmente também melhorias muito importantes nos sistemas de transportes e comunicações levaram nas últimas décadas do século XX a um novo padrão de especialização no comércio internacional não previsível algumas décadas antes ${ }^{146}$.

De forma a quebrar "com o padrão tradicional do comércio internacional, em particular entre países com graus diversos de desenvolvimento, era o padrão de comércio de bens finais diferentes, com as cadeias de produção integralmente nos países respectivos"147, uma vez que, "com esta evolução, vemos um número crescente de países a exportar e importar produtos dos mesmos setores"148 que "acontece tanto no comércio de bens finais como no comércio de bens intermediários (inputs), como as empresas a compra-los onde são fornecidos em condições mais favoráveis (outsourcing)" $" 149$.

\footnotetext{
${ }^{143}$ Faria, 2010, posição 368-379.

${ }^{144}$ Ibid.

${ }^{145}$ Amador, 2017, pp. 23-25.

${ }^{146}$ Porto, 2017, p. 532.

${ }^{147}$ Ibid., p. 531.

${ }^{148}$ Ibid., p. 532.

${ }^{149}$ Ibid.
} 
Assim, as chamadas "cadeias de valor globais"150 ou "cadeias de produção globais" 151 , frutos de "um forte crescimento de fluxos comerciais de partes e componentes que são utilizadas como input de outros produtos"152, dado que "os produtos (desde alimentos processados aos aparelhos eletrônicos, passando pelos automóveis) vão incorporando matérias-primas, componentes e serviços introduzidos em diferentes países ao longo da cadeia de valor, até chegar ao produto final" ${ }^{153}$. Tal "fragmentação da cadeia produtiva" ${ }^{154}$, por sua vez, retroalimenta o processo de integração/interdependência das economias e resulta "numa completa reconfiguração do comércio mundial em termos de participantes e vantagens comparativas" 155 , contexto em que "a identidade nacional de produtos e das empresas que os fornecem fica cada vez mais difícil de ser identificada" ${ }^{156}$.

Como consequência dessa "reorganização industrial", via fragmentação da produção", há os que defendem o surgimento de uma "nova divisão internacional do trabalho" que leva em consideração não só os fatores tradicionais como custo direto da mão de obra e custo de matérias-primas, mas também "incentivos fiscais, subvenções estatais, neutralização de pressões trabalhistas e ativismo sindical e inefetividade ou até inexistência de leis de proteção ambiental"157, aumentando a pressão sobre os governos de uma forma geral para facilitar suas regulamentações a fim de atrair mais capital estrangeiro, fato que faz crescer a tese de que tal pressão leva os países a diminuírem seus padrões de proteção social com o intuito de aumentar sua competitividade ${ }^{158}$. Dessa forma, os Estados de bem-estar social desenvolvidos são compelidos a encetar políticas que visam desgastar os níveis de proteção e regulação social já estabelecidos, enquanto os estados de bem-estar social subdesenvolvidos desvinculam políticas sociais do nível de crescimento econômico com o propósito de manter uma suposta vantagem comparativa a beneficiar os agentes econômicos domésticos e atrair investimentos estrangeiros ${ }^{159}$.

\footnotetext{
${ }^{150}$ Amador, 2017, pp. 23-25.

${ }^{151}$ Moreira, 2014, p. 29.

${ }^{152}$ Amador, op. cit., loc. cit.

${ }^{153}$ Moreira, op. cit., loc. cit.

${ }^{154}$ Ibid.

${ }^{155}$ Ibid.

${ }^{156}$ Thorstensen, V. (1998). A OMC - Organização Mundial do Comércio e as negociações sobre investimentos e concorrência. Rev. bras. polit. int., Brasília, v. 41, n. 1, pp. 57-89. Disponível em: $<$ http://www.scielo.br/scielo.php?script=sci_arttext\&pid=S0034-73291998000100004\&lng=en\&nrm=iso $>$. Acesso em: 18 fev. 2019.

${ }^{157}$ Ibid.

${ }^{158}$ Bunescu, 2011, pp. 11-13.

${ }^{159}$ Ibid.
} 
Em alternativa a tal entendimento, há os que defendem que os países pioneiros na implementação do estado social tiveram de passar por uma série de experimentações, processos de tentativa-erro, que os fizeram majoritariamente adotar um modelo do tipo repartição intergeracional que não se mostra adequado aos novos tempos, especialmente em função da rápida transformação ao nível demográfico nesses países. Esta experiência, por conseguinte, desoneraria os "recém-chegados" ao welfare state de arcar com os mesmos experimentalismos pelo quais passaram os pioneiros, calhando nestes a opção de aderir diretamente a esquemas de pensões baseadas, por exemplo, em capitalização de fundos ${ }^{160}$. Essa visão alternativa prega que:

[...] à medida que mais países se tornam parte de um sistema internacional ou regionalmente integrado, o cenário mais provável não seja nem uma corrida para o fundo nem uma "harmonização ascendente", mas uma "convergência à média" no sentido de que os principais estados de bem-estar social limitam seus deveres, enquanto os países mais atrasados expandem sua rede de proteção ${ }^{161}$.

Tais movimentos de desmonte do welfare state, bem como de flexibilização das normas laborais, são especialmente tempestuosos nos países de alto padrão, em geral pelo fato de serem regimes democráticos em que qualquer corte nos gastos sociais são extremamente impopulares e podem levar a protestos, instabilidade política e fulminar a legitimidade dos formuladores de políticas públicas que, por sua vez, se veem tentados a impor seu nível e modelo de proteção aos demais países de padrão inferior sob a retórica da concorrência injusta ou desleal ${ }^{162}$.

Ao fim, importa destacar que a arena global é hoje resultado de uma longa e complexa trama que vem se aprofundando, pois está sempre em movimento e, apesar de não comportar diagnósticos e soluções simples, fornece os instrumentos necessários àqueles que preferem perceber a realidade a partir dos próprios interesses.

\subsubsection{O discurso do dumping social: neoprotecionismo e polarização entre PAD e PED}

Barral, ainda nos idos do ano 2000, observa que:

\footnotetext{
${ }^{160}$ Bunescu, 2011, pp. 11-13.

${ }^{161}$ Ibid.

${ }^{162}$ Ibid.
} 
[...] um dos novos temas do comércio internacional envolve a tentativa de ampliar o conceito de dumping para caracterizar a concorrência internacional firmada sobre diferenças estruturais entre países desenvolvidos e em desenvolvimento. Esta tentativa, [...] aponta, como mecanismos de concorrência desleal, certas distinções econômico-sociais dos países em desenvolvimento. [...] assim, torna-se usual a utilização das expressões "dumping social", "dumping cambial", "dumping ambiental"163.

$\mathrm{O}$ autor segue de forma assertiva e fecha o prognóstico acerca da questão ao asseverar que:

[...] a tentativa de conceituação de dumping social é vista, pelos países em desenvolvimento, como uma tentativa de criar novas barreiras protecionistas à exportação de seus produtos. Tal posicionamento defensivo da maioria dos membros da OMC deve impedir a materialização normativa do conceito no futuro próximo ${ }^{164}$.

Fato é que, desde Bretton Woods e, até há bem pouco tempo, as grandes potências mundiais pressionavam os países em desenvolvimento a abrirem suas economias com o objetivo de expandir o mercado de suas indústrias, destacando-se as de tecnologia. Os PED, mesmo sob forte pressão dos produtores nacionais, aos poucos foram cedendo à persuasão dos hegemônicos e se abriram ao livre comércio em escala mundial.

Tudo vinha funcionando a contento para as potências mundiais, pois a superioridade, em termos de tecnologia, câmbio, capacidade de inovação e investimento, não permitia uma concorrência justa entre eles e os demais, contudo, "a liberalização do comércio internacional, acompanhada da liberalização do investimento direto estrangeiro, pode propiciar a (des)localização de empresas nos países com menores custos de produção, incluindo os custos salariais, ambientais, etc." ${ }^{165}$, ou seja, nos últimos anos, os PED, em consonância com a teoria de Ricardo, vêm se aperfeiçoando no aproveitamento de suas vantagens inatas e, por conta disso, acumulando capital e tornando-se cada vez mais competitivos, atraindo indústrias via deslocalização, provocando desemprego nos países que, antes, dominavam de forma absoluta o jogo do livre comércio ${ }^{166}$.

\footnotetext{
${ }^{163}$ Barral, 2000, p. 13.

${ }^{164}$ Ibid., p. 14.

${ }^{165}$ Moreira, 2014, p. 30.

${ }^{166}$ Segundo Stiglitz e Chalton (2009, p. 160): “a maior parte do progresso em negociações comerciais durante o meio século passado centrou-se em torno da liberalização da manufactura (em vez de nos têxteis) - os bens que são de importância crescente para os países em vias de desenvolvimento de rendimento médio. Há uma certa ironia: enquanto Estados Unidos e a Europa podem ter pensado que estavam a negociar acordos
} 
Uma vez que já estavam consolidados os conceitos subjacentes ao livre comércio, os países ditos de primeiro mundo trataram de recorrer às chamadas "barreiras não tarifárias" ou "barreiras não visíveis" com intuito de proteger os setores mais afetados pela abertura dos mercados, notadamente na indústria têxtil, de calçados ou siderúrgica ${ }^{167}$.

Desse modo, uma miríade de "formalidades administrativas" e "especificações técnicas" tomaram forma de barreiras de natureza técnicas, sanitárias, ambientais, sociolaborais, etc. que visam proteger setores específicos da economia interna de certos países, constituindo-se, assim, em "restrições comerciais que (dolosamente) travam o processo orientador para o pleno desenvolvimento das trocas internacionais" 168 .

É o que Bouët chama de "os novos instrumentos do protecionismo" ou o neoprotecionismo que, segundo o autor, têm características diferentes do protecionismo clássico, com destaque para o fato de que essas novas barreiras ao comércio são dinâmicas e opacas ${ }^{169}$, o que significa dizer também que, por não serem compatíveis com o atual sistema multilateral de comércio internacional, não são explícitas, estão geralmente camufladas na forma de políticas legítimas e reconhecidas pela Organização Mundial do Comércio, como, no que interessa ao presente texto, nas medidas de defesa comercial, mais especificamente nos direitos ou medidas antidumping, conforme se constatará mais adiante.

Nesse contexto, os setores da indústria tradicional dos PAD que não conseguem competir com os novos players baseados nos países em desenvolvimento passam a pressionar seus governos visando bloquear a entrada desses produtos no mercado nacional, tudo mediante um discurso sobre a "injustiça" e a "deslealdade" nas relações comerciais internacionais, transformando a legítima necessidade de se observar os standards sociais em instrumento de política protecionista com apelo populista ${ }^{170}$. Com isso:

[....] os países em desenvolvimento rejeitam a vinculação dos padrões trabalhistas na OMC. Eles questionam o motivo de países como os Estados Unidos, que não retificaram a maioria das Convenções da OIT e cujos trabalhadores apresentam baixo

comerciais que eram de maior benefício para si, na realidade negociaram um regime de comércio global que, se for posto em prática com justiça (e pondo de lado as barreiras não-pautais), é provável no futuro ser de maior benefício para a China e outros países em vias de desenvolvimento de rendimento médio."

${ }^{167}$ Porto, M. C. L. (1986). Protecionismo. In: Polis: Enciclopédia Verbo da Sociedade e do Estado, vol. 04. Lisboa: Verbo, p. 1671

${ }^{168}$ Gava, 2008, p. 87.

${ }^{169}$ Tradução nossa. No original: "Les nouveaux intruments $d u$ protectionisme" e os descreve como "les nouvelles entraves à l'echange sont souvent disminatires mais se distinguent surtout par leur opacité [...]" (Bouët, 1998, pp. 17-21).

${ }^{170}$ Gava, op. cit., loc. cit. 
grau de sindicalização, estarem tão interessados em empregar retaliações comerciais como arma para garantir padrões trabalhistas ${ }^{171}$.

Dessa forma, o termo "dumping social" está, na verdade, mais associado ao discurso político que busca legitimar medidas neoprotecionistas ${ }^{172}$ do que à busca da melhoria das condições laborais dos "terceiro-mundistas". Ou seja, tal retórica, em grande medida, tem por escopo imediato a legitimação de ações que visam burlar as regras comerciais internacionais em razão de interesses de agentes econômicos deficientes.

Assim, no âmbito do subsistema multilateral de comércio, o discurso (a acusação ${ }^{173}$ ou o argumento ${ }^{174}$ ) do dumping social aponta uma suposta prática de dumping a partir da utilização de mão de obra com custo mais baixo viabilizada por países em desenvolvimento que não oferecem um padrão de proteção social tão rígido quanto o encontrado nos países desenvolvidos, na intenção de proporcionar a empresas que lá mantêm plantas de produção um menor custo de operacional e, por conseguinte, atrair investimento estrangeiro por meio de (injusta) vantagem comparativa.

Em rasa análise, estar-se-á a falar da prática realizada por países que, deliberadamente, inobservam supostos standards de bem-estar social com o intuito de conferir às empresas que ali operam custos trabalhistas inferiores, tornando os bens lá produzidos mais baratos, ou seja, salários baixos e escassas condições de trabalho ajudavam a manter baixos os custos de produção e, portanto, poderiam ser vistos como um ilegítimo subsídio à exportação e uma vantagem competitiva injusta, pois teria por base a redução dos custos e não o aumento da produtividade ${ }^{175}$.

As teorias que alicerçam a existência do dumping social partem da premissa de que os países desenvolvidos tendem a cobrir seus trabalhadores com amplo acesso a direitos sociais e boa remuneração, garantindo aos seus cidadãos acesso ao trabalho digno e justo, ao passo que os países que não alcançaram mesmo nível de desenvolvimento não garantem o mesmo patamar de proteção social ou nível salarial aos seus trabalhadores. A partir dessa

\footnotetext{
${ }^{171}$ Casagrande \& Antunes, 2016, p. 124.

${ }^{172}$ É o que Bouët (1998, pp. 17-21) chama de "Les nouveaux intruments du protectionisme" e os descreve como "les nouvelles entraves à l'echange sont souvent disminatires mais se distinguent surtout par leur opacité." ${ }^{173}$ Bunescu, 2011, pp. 11-13.

${ }^{174}$ Moreira, 2014, p. 37.

${ }^{175}$ Bernaciak, M. (2012). Social Dumping: Political Catchphrase or Threat to Labour Standards? In: SSRN Electronic Journal, 10.2139/ssrn.2208393, p. 09. Disponível em: $<$ https://www.researchgate.net/publication/256045521 Social_Dumping_Political_Catchphrase or Threat t o_Labour_Standards $>$. Acesso em: 25 jul. 2018.
} 
"constatação", o discurso do dumping social dá por certo que o avanço do livre-cambismo e a crescente integração/competição econômica entre países de baixo e alto padrão irá desencadear um processo de race to the botton que, em tese, degradaria os padrões sociais em todo o mundo.

Bernaciak, contudo, alerta que considerar os baixos salários como equivalentes ao dumping social é problemático por pelo menos três razões: primeiro, há que se levar em consideração as diferenças de produtividade entre ambientes de alto e baixo padrão remuneratório, já que, segundo a autora, a produtividade tende a ser muito menor nos países mais pobres; em segundo lugar, não se pode ignorar os níveis divergentes de desenvolvimento econômico e social dos países e o fato de que os países mais pobres tendem, naturalmente, a melhorar seus padrões por meio dos benefícios do comércio e da integração econômica com nações de alto padrão; por fim, a estudiosa destaca o fato de que é um erro afirmar que as práticas associadas à ideia de dumping social são exclusivamente perseguidas por agentes econômicos sedeados em países pobres ou em desenvolvimento, não sendo incomum o uso do discurso do dumping social para legitimar o lobby e o achaque de grandes multinacionais, saudáveis do ponto de vista financeiro, a governos e sindicatos dos trabalhadores dos países desenvolvidos ${ }^{176}$.

Aqui, é possível afirmar que o discurso do dumping social carece de legitimidade pois faz uso de um questionável trade off entre livre-cambismo e standards sociais para ganhar ressonância e, portanto, visibilidade, quando, na verdade, há muito se sabe que o comércio internacional não é um jogo de soma zero e que o melhor caminho para se implementar melhoras nos padrões sociolaborais dos países em desenvolvimento "está na promoção do seu crescimento econômico - e este passa por uma maior participação no comércio internacional" ${ }^{177}$.

\subsubsection{A legítima demanda por desenvolvimento}

O movimento de construção da noção de desenvolvimento econômico como instrumento de realização de todos os direitos humanos e liberdades fundamentais tem como

\footnotetext{
${ }^{176}$ Bernaciak, 2012, pp. 16-17.

${ }^{177}$ Cunha, 2001, p. 18.
} 
marco inicial a fase de descolonização que tomou lugar na década de $1960^{178}$ e como apogeu a Declaração sobre o Direito ao Desenvolvimento, aprovada pela Resolução 41/128 da Assembleia Geral da ONU, em 1986, com 146 votos a favor, um voto contra (Estados Unidos) e oito abstenções (incluindo Alemanha, Japão e Reino Unido) ${ }^{179}$.

Em suma, a declaração da ONU estabelece, logo no artigo $1 .^{\circ}$, o direito ao desenvolvimento como um direito humano que se concretiza via equalização do acesso de todos às fontes do desenvolvimento e na justa partilha do bem-estar econômico e social a ele inerentes. Para tanto,

[...] os Estados nacionais têm a responsabilidade de promover a realização do direito ao desenvolvimento através de políticas adequadas em favor do desenvolvimento. Outros Estados e organizações internacionais têm a obrigação de cooperar com os Estados nacionais para facilitar a realização do processo de desenvolvimento ${ }^{180}$.

Dito isto, quando o tema é dumping social, os discursos públicos dos líderes dos PAD apontam o menor custo da mão de obra e o baixo nível de proteção social como vantagens comparativas injustas utilizadas propositalmente pelos PED com o desleal propósito de fortalecer os agentes econômicos internos e deslocalizar aqueles referenciados nos países hegemônicos.

Noutra senda, os representantes dos PED argumentam que os salários e a proteção sociolaboral lá praticados são reflexos ou expressão dos seus respectivos níveis de desenvolvimento econômico e, consequentemente, só podem ser incrementadas mediante crescimento sustentável e contínuo de suas economias que, para isso, passa irremediavelmente pela ampla participação dessas nações no comércio internacional. Dessa forma, o discurso do dumping social, antes de homenagear os direitos sociolaborais dos

\footnotetext{
${ }^{178}$ Peixinho, M. M. \& Ferraro, S. A. (2003). Direito ao desenvolvimento como direito fundamental. Disponível

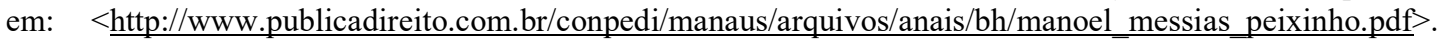
Acesso em: 20 mai. 2018.

${ }^{179}$ Nwauche, E. S. \& Nwobike, J. C. (2005). Implementing the right to development. Sur, Rev. int. direitos human., São Paulo, v. 2, n. 2, pp. 96-117. Disponível em:

$<$ http://www.scielo.br/scielo.php?script=sci_arttext\&pid=S1806-64452005000100005\&lng=en\&nrm=iso $>$. Acesso em: 25 jul. 2018.

${ }^{180}$ Negrini, M. C. (2013). O direito ao desenvolvimento na esfera das Nações Unidas. Disponível em: $<$ https://jus.com.br/artigos/23957/o-direito-ao-desenvolvimento-na-esfera-das-nacoes-unidas $>$. Acesso em: 25 jul. 2018.
} 
trabalhadores do "terceiro mundo", acaba, a bem da verdade, por negar-lhes o direito fundamental ao desenvolvimento econômico ${ }^{181}$.

\subsubsection{Da pragmática normatização do dumping no comércio internacional à polêmica da cláusula social}

Apesar de amplamente difundido nos discursos proferidos na $\mathrm{OMC}$, qualquer tentativa de conceituação de dumping social não encontra base normativa específica, assim, a busca por delimitar o fenômeno enquanto objeto do Direito remete à análise do gênero, o dumping (comercial).

Neste ponto, já é possível perceber que casos como os alardeados pelo discurso do dumping social já se encontram objetivamente abrangidos pelo atual direito da $\mathrm{OMC}$, já que os episódios em que os agentes econômicos de um de seus Estado-membros venham a oferecer produtos ou serviços a um outro EM a preço abaixo do "normal", sendo este obtido por meio do fomento estatal à prática de salários baixos e de péssimas condições de trabalho com o intuito de causar dano à concorrência e atrair investimento estrangeiro, poderá, sim, ser alvo de direitos ou medidas antidumping, bastando que, para isto, o país receptor comprove o prejuízo ao seu setor industrial ou ao seu potencial de industrialização.

Em arremate, a inafastável conclusão é a de que, considerando o objeto do sistema multilateral de comércio e, por conseguinte, do direito da $\mathrm{OMC}$, não faz qualquer sentido prático se falar em uma legislação específica para o dumping derivado de padrões sociolaborais; pelo contrário, tal distinção representa uma perigosa ameaça à integridade e à confiabilidade do Sistema de Resolução de Conflitos, conforme se verá mais adiante.

Entretanto, em face da inexistência de previsão específica sobre dumping social, tanto no sistema normativo GATT/OMC, quanto no da OIT, é que, desde os primórdios da regulamentação do comércio internacional, os Estados Unidos da América ${ }^{182}$ protagonizam $^{2}$ tentativas de inclusão de padrões trabalhistas nas rondas de negociação, com destaque para o Acordo de Marrakesh (EUA e França), na conclusão da Rodada Uruguai e para a

\footnotetext{
${ }^{181}$ Bernaciak, 2012, p. 12.

182“Logo em 1953 os Estados Unidos propuseram adicionar uma cláusula dos direitos dos trabalhadores ao GATT, de modo a permitir o desrespeito desses direitos como uma modalidade de 'anulação ou redução' das vantagens asseguradas pelo sistema multilateral de comércio internacional, para efeitos do art. XXIII do GATT" (Moreira, 2014, p. 97).
} 
Declaração Ministerial de Cingapura em 1996 (EUA, apoiado por Canadá, Japão e alguns países da Europa, com destaque para a Noruega).

Pelas propostas apresentadas, a vinculação do comércio internacional a padrões sociolaborais mínimos se daria com a "cláusula social”, um dispositivo que deveria constar de tratados com matéria comercial visando essencialmente combater o dumping social, permitindo a utilização do Sistema de Resoluções de Conflitos da OMC para aplicação de sanções comerciais a países que não respeitassem tais standards ${ }^{183}$. Contudo, fícou estabelecido no ponto 4 da Declaração Ministerial de Cingapura que:

We renew our commitment to the observance of internationally recognized core labour standards. The International Labour Organization (ILO) is the competent body to set and deal with these standards, and we affirm our support for its work in promoting them. We believe that economic growth and development fostered by increased trade and further trade liberalization contribute to the promotion of these standards. We reject the use of labour standards for protectionist purposes, and agree that the comparative advantage of countries, particularly low-wage developing countries, must in no way be put into question. In this regard, we note that the WTO and ILO Secretariats will continue their existing collaboration ${ }^{184}$.

Mediante persistência, a questão precisou ser abordada novamente em 2001 na $4 .^{a}$ Conferência Ministerial em Doha, cujo ponto 8 da respectiva declaração foi incisivo:

It is important that the 28 applicants now negotiating accession contribute to completing the accession process by accepting the WTO rules and by offering meaningful market access commitments. We will work to bring these applicants expeditiously into the WTO system ${ }^{185}$.

\footnotetext{
183“'O objetivo de vincular os padrões trabalhistas à OMC deve-se ao fato de que a OIT não dispõe de um mecanismo coercitivo, ao contrário da $\mathrm{OMC}$, que possui um Sistema de Resolução de Controvérsias com significativos índices de cumprimento das suas decisões. Assim caberia à OMC fiscalizar o cumprimento da cláusula social e aplicar as medidas coercitivas cabíveis" (Casagrande \& Antunes, 2016, p. 124).

${ }^{184}$ World Trade Organization. (1997). Singapore Ministerial Declaration. [on-line]. Disponível em: $<$ https://www.wto.org/english/thewto_e/minist e/min96 e/wtodec e.htm>. Acesso em: 27 jul. 2018. Tradução nossa: "A Organização Internacional do Trabalho (OIT) é o órgão competente para definir e lidar com esses padrões [...] Rejeitamos o uso de normas trabalhistas para fins protecionistas e concordamos que a vantagem comparativa dos países, particularmente os países em desenvolvimento de baixos salários, não deve, de forma alguma, ser questionada".

${ }^{185}$ World Trade Organization. (2001). Doha WTO Ministerial Declaration [on-line]. Disponível em:

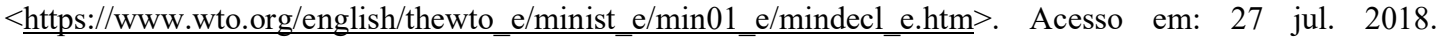
Tradução nossa: "Reafirmamos nossa declaração feita na Conferência Ministerial de Cingapura sobre os padrões fundamentais de trabalho reconhecidos internacionalmente. Tomamos nota do trabalho em curso na Organização Internacional do Trabalho (OIT) sobre a dimensão social da globalização".
} 
Aqui, é relevante lembrar que a OIT mantém, desde a sua fundação, uma produção normativa vigorosa, com destaque para 189 convenções, das quais:

[...] no que diz respeito à relação entre comércio internacional e padrões trabalhistas, a discussão envolve oito convenções tidas como pilares da OIT, que são divididas em quatro categorias: liberdade de associação e de negociação (convenções 87 e 98); eliminação do trabalho forçado e escravo (convenções 29 e 105); eliminação da discriminação em relação ao emprego e à ocupação (convenções 100 e 111); e abolição do trabalho infantil (convenções 138 e 182) ${ }^{186}$.

Em tempo, merece ênfase o fato de que, dessas 189 convenções da OIT, apenas 14 foram ratificadas pelos Estados Unidos; destaque-se, ainda, que, das oito convenções sobre direitos humanos fundamentais, apenas duas foram ratificadas pelos EUA: a Convenção 105 sobre abolição do trabalho forçado e Convenção 182 versando acerca da abolição do trabalho infantil. Para efeito de comparação, Portugal ratificou 84 convenções incluindo todas as fundamentais; o Brasil 97 e sete das oito fundamentais; e a China, que ocupa posição de destaque no discurso do dumping social, ratificou 26 convenções, dentre as quais, quatro das oito fundamentais ${ }^{187}$.

À vista disso, a OMC declara-se incompetente como foro de criação de normas e para resolução de conflitos na matéria e reconhece o cunho protecionista que impulsiona as propostas de cláusula social, evitando, por sua vez, prejudicar o incremento do livre comércio e os consequentes prejuízos ao desenvolvimento econômico dos PED.

Já a OIT lembra no ponto 5 da Declaração sobre Princípios e Direitos Fundamentais do Trabalho, de 1998, que "as normas do trabalho não deveriam utilizar-se com fins comerciais protecionistas e que nada na presente Declaração e seu seguimento poderá invocar-se nem se utilizar de outro modo com esses fins" 188 .

\footnotetext{
${ }^{186}$ Casagrande \& Antunes, 2016, p. 123.

${ }^{187}$ International Labor Organization. (1996-2017). Ratifications by country. [on-line]. Disponível em: $<$ https://www.ilo.org/dyn/normlex/en/f?p=1000:11001:::NO:::\#F>. Acesso em: 26 jul. 2018.

${ }^{188}$ International Labor Organization. (1998). Declaração da OIT sobre os Princípios e Direitos Fundamentais no trabalho. [on-line]. Disponível em:

$<$ https://www.ilo.org/public/english/standards/declaration/declaration portuguese.pdf $>$. Acesso em: 02 mai. 2019.
} 
2.2.4.1 A cláusula social e o risco de "deslegalização" da OMC

O conceito de legalização trabalhado por Abbott, Keohane, Moravcsik, Slaughter e Snidal parte de um conjunto particular de características que as instituições podem (ou não) possuir. Essas características são definidas a partir de três dimensões: obrigação, precisão e delegação ${ }^{189}$.

Os autores explicam que "obrigação" significa que os Estados, ou outros atores, estão vinculados por uma regra ou compromisso ou por um conjunto de regras ou compromissos, de modo que seu comportamento é submisso ao escrutínio sobre as regras gerais, procedimentos e discurso do Direito Internacional e, frequentemente, também do direito interno; já a "precisão" se constitui por regras inequívocas na conduta que eles exigem, autorizar ou proscrever; por fim, por "delegação" entendem ser o fato de terceiros receberem autoridade para implementar, interpretar e fazer cumprir as regras, para resolver disputas e, possivelmente, para elaborar mais regras ${ }^{190}$.

Nessa perspectiva, não existe uma dicotomia rígida - cada uma dessas dimensões é uma questão de grau e gradação e cada uma delas pode variar de forma independente. Logo, o conceito de legalização engloba um contínuo multidimensional, variando do "tipo ideal" de legalização, onde todas as três propriedades são maximizadas; a "hard legalization", onde todos os três (ou pelo menos obrigação e delegação) são altos; através de múltiplas formas de legalização parcial ou "soft legalization", envolvendo diferentes combinações de atributos; e, finalmente, a completa ausência de legalização, outro tipo ideal ${ }^{191}$.

Desse modo, instituições internacionais altamente legalizadas são aquelas cujas próprias regras estabelecem forte ligação as normas e princípios estabelecidos no Direito Internacional, com alto grau de precisão e cuja autoridade para interpretá-las e aplicá-las foi delegada por seus membros ${ }^{192}$. Necessário, ainda, que seus processos legais envolvam um discurso enquadrado em termos de razão, interpretação, conhecimento técnico e discussão, seguidos de deliberação e julgamento por partes imparciais, cujas decisões legais também

\footnotetext{
${ }^{189}$ Abbott, K.; Keohane, R.; Moravcsik, A.; Slaughter, A. \& Snidal, D. (2000). The Concept of Legalization. International Organization. In: International Organization, v. 54, n. 3, pp. 401-419. Disponível em: $<$ https://www.cambridge.org/core/journals/international-organization/article/the-concept-oflegalization/EF6AA703676B5053168AC43C27BF45A4>. Acesso em: 28 jul. 2018.

${ }^{190}$ Ibid.

${ }^{191}$ Ibid.

${ }^{192}$ Ibid.
} 
devem se basear em razões aplicáveis a todos os litigantes semelhantemente situados, não apenas às partes da disputa imediata ${ }^{193}$.

Os próprios autores apontam a OMC como uma instituição internacional altamente legalizada, ou seja, com elevado número de Estados-membros a se comprometerem com suas regras que, por sua vez, são marcadas pela clareza, objetividade e pragmatismo, culminando com um sistema de resolução de conflitos o mais apolítico possível ${ }^{194}$.

Todavia, de acordo com o discurso do dumping social, a intencionalidade é um elemento central, uma vez que este pressupõe a prática de baixas remunerações e péssimas condições de trabalho como cerne da desleal estratégia comercial de um país visando causar dano à concorrência, atrair investimento e obter vantagem comparativa no comércio internacional. Dessa maneira, a derivação da investigação de dumping social a partir da de dumping (comercial) implicaria na apuração desta intencionalidade, evitando, por justeza, punir àqueles membros cujos padrões sociolaborais derivam exclusivamente do seu estágio de desenvolvimento.

A introdução da "intencionalidade" enquanto elemento altamente subjetivo, na processualística do $\mathrm{ORC} / \mathrm{OMC}$, tem o condão de fulminar com a sua capacidade jurisdicional, nomeadamente no que tange a sua dimensão da precisão, já que, por exemplo, há que se aclarar qual seria o padrão sociolaboral expectável ao país investigado; para tanto, é inafastável analisar além dos números, quais são as nuances históricas, sociais e políticas que compõem a cultura do trabalho daquela sociedade.

Em vista disso, a diminuição do nível de precisão das regras da OMC implicaria num necessário aumento da delegação de autoridade dos seus membros, movimento do qual, obviamente, a grande maioria desses membros não estaria disposta a participar, já que existe o receio de que a normatização do dumping social traga a subjetividade necessária à politização do sistema de resolução de conflitos da $\mathrm{OMC}$, transformando-o em instrumento de protecionismo a serviço dos interesses dos países hegemônicos.

Posto isso, é preciso perceber que a normatização do dumping social no âmbito da OMC iria introduzir subjetividade e provocar a politização do seu Sistema de Resolução de Conflitos, culminando com a sua "deslegalização", pois lhe afetaria negativamente as três dimensões da legalização: precisão, delegação e obrigação. Assim, a tendência seria de que

\footnotetext{
${ }^{193}$ Abbott; Keohane; Moravcsik; Slaughter \& Snidal, 2000, pp. 401-419.

${ }^{194}$ Ibid.
} 
a maioria dos membros da OMC deixassem de reconhecer a sua autoridade para implementar, interpretar e fazer cumprir as regras, tudo em razão da sua transmutação em foro de legitimação do neoprotecionismo.

2.2.4.2 Soluções viáveis para elevação das condições sociolaborais no multilateralismo

Grande parte do pensamento econômico que alicerça o corrente modelo de produção e distribuição de riquezas leva a crer que o caminho mais seguro para a elevação das condições sociolaborais em todo o mundo, em especial nos países menos desenvolvidos, é a promoção do desenvolvimento econômico sustentável via aprimoramento do comércio mundial, e esta é a missão da OMC.

Por outro lado, e tão importante quanto, é a atuação da Organização Internacional do Trabalho que, desde a década de 1990, vem trabalhando a noção de trabalho digno com "quatro objetivos estratégicos da organização, a saber, normas e princípios fundamentais nas relações de trabalho, emprego, proteção social e diálogo social" 195 por meio da chamada decent work agenda, cuja implementação se dá via "programas nacionais, adaptados às necessidades de cada país"196, sempre destacando a igualdade de gênero como valor transversal ${ }^{197}$.

Esses objetivos são viabilizados por seu peculiar modelo de produção e promoção de normas trabalhistas que, por sua vez, criou e implementou em 1994 a World Commission on the Social Dimesion of Globalization ${ }^{198}$, grupo que busca identificar problemas e fornecer subsídios para criar oportunidades econômicas a todos a partir da concepção de que o desenvolvimento econômico consequente da liberalização do comércio internacional deve ser aproveitado para promover a melhoria dos padrões de trabalho e aumento do emprego.

A OIT também elabora guias práticos para autoridades públicas, empregadores e trabalhadores envolvidos, visando o desenvolvimento e aplicação de uma cultura preventiva de segurança e saúde nos locais de trabalho em todo o mundo. Assim, o SafeWork, Programa de Segurança e Saúde no Trabalho e Meio Ambiente da OIT, visa criar uma consciência

\footnotetext{
${ }^{195}$ Moreira, 2014, p. 60.

${ }^{196}$ Ibid.

${ }^{197}$ Bunescu, 2011.

${ }^{198}$ International Labor Organization. (2004). World Commission on the Social Dimension of Globalization. [on-line]. Disponível em: <https://www.ilo.org/public/english/wcsdg/index1.htm>. Acesso em: 18 fev. 2019.
} 
mundial das dimensões e consequências dos acidentes, lesões e doenças relacionadas com o trabalho ${ }^{199}$.

Outra forma de atuação da OIT se dá através de inovações como o "selo social" ou "etiqueta social" que, conforme Portela:

[...] foi proposta [...] em 1998, e consistia [...] num sistema de marcas que deveriam ser estampadas nas embalagens de produtos destinados à exportação como comprovação de que tais mercadorias foram produzidas em consonância com padrões trabalhistas mínimos [...]. O selo pode ser conferido por organizações internacionais, entidades empresariais, ONGs etc. ${ }^{200}$.

Dessa forma, seria mais lógico conferir mais força política à OIT, "que é a única organização internacional tripartite, com a presença de governos, empresários e trabalhadores"201, do que transformar a OMC em tutora de temas que não estão objetivamente relacionados ao comércio, transformando-a num "tribunal de cunho mais político e social do que comercial"202 - em outras palavras, não permitir que os abusos já observados no âmbito da aferição e processamento do dumping (comercial), como os verificados na polêmica em torno do zeroing, prospere, via inclusão de padrões morais, critérios subjetivos e potencialmente discricionários, no seio da OMC.

Noutra senda, Bernaciak destaca a importância da intensificação dos contatos transnacionais entre os sindicatos, posto que "os interesses dos trabalhadores e de outros atores da sociedade nos países de baixo e alto padrão não são necessariamente divergentes, e que há espaço para alianças transnacionais em apoio à convergência dos padrões de emprego" ${ }^{203}$. Através desse nível de interação sindical é que se viabilizará o papel de stakeholders ${ }^{204}$ no atual estágio de globalização.

Somado a tudo isso, importa aclarar que a retórica na qual se baseia a proposta da “cláusula social” foi rejeitada pela OMC por ser, essencialmente, polarizadora. Não obstante,

\footnotetext{
${ }^{199}$ Bunescu, 2011.

${ }^{200}$ Portela, 2016, p. 500.

${ }^{201}$ Thorstensen, 1998, p. 52.

${ }^{202}$ Ibid., p. 51.

${ }^{203}$ Tradução nossa. "This indicates that the interests of workers and other societal actors in low-and highstandard countries are not necessary divergent, and that there is room for cross-border alliances in support of the upward convergence of employment standards" (Bernaciak, 2012, p. 18).

${ }^{204}$ Moreira, 2014, p. 75.
} 
eventuais soluções para os impasses consequentes da globalização são, por natureza, complexos e pedem colaboração e não confrontação 205 .

\subsection{O discurso do dumping social no subsistema regional de comércio internacional}

É cediço que, por seu propósito, esta dissertação não se presta a proceder a uma abordagem que avance em pormenor sobre todo o subsistema regional de comércio internacional, pelo que o presente capítulo se debruçará na questão do discurso do dumping social onde este é mais proeminente, ou seja, na União Europeia. Contudo, à guisa de introdução, vale destacar, ainda que timidamente, a discussão que se faz constar em outros elementos desse subsistema, em especial no âmbito do NAFTA/USMCA.

Assim, em que pese ser abstrusa a empreita de se apontar um marco para o discurso do dumping social no subsistema regional de comércio internacional, Bernaciak destaca o período que antecedeu a conclusão do Acordo de Livre Comércio da América do Norte (NAFTA), no início dos anos de 1990, como o momento em que a temática se estabeleceu no discurso público em razão das polêmicas levantadas por sindicatos, ativistas sociais e ambientais dos Estados Unidos da América e Canadá ao apontarem que os níveis salariais significantemente mais baixos, regulamentos sociais e ambientais mais frágeis, bem como um "insatisfatório" histórico de fiscalização nestas áreas, confeririam ao México uma vantagem competitiva injusta no futuro bloco ${ }^{206}$.

Tal pressão se fez sentir e o pacto do NAFTA foi complementado por acordos paralelos sobre questões ambientais e trabalhistas, dentre os quais destacamos o Acordo Norte-Americano sobre Cooperação Trabalhista (NAALC), através do qual os três membros se comprometeram a fazer valer seus respectivos regulamentos trabalhistas ${ }^{207}$, ou seja, ao invés da adoção em conjunto de determinados padrões trabalhistas, os membros do NAFTA optaram por um modelo simples de cooperação em que cada país assume o compromisso de aplicar eficazmente as próprias leis nacionais; tal iniciativa levou a alguns sindicatos a apontarem o acordo paralelo como sendo um documento meramente "aspiracional" e não

\footnotetext{
${ }^{205}$ Isto posto, é necessário aclarar que a posição aqui adotada não é unânime; ao contrário, existem estudiosos de grande relevo que defendem o modelo da "cláusula social" como "meio de reconciliar o comércio internacional com os direitos fundamentais dos trabalhadores e vice-versa" - quem o faz com brilhantismo é o Professor Doutor Vital Moreira (2014, p. 240).

${ }^{206}$ Ibid., p. 07.

${ }^{207}$ Ibid., p. 08.
} 
aplicável, cujas regras mostraram-se inexequíveis e ineficazes ante as ameaças de realocação de investimentos e perda de empregos, pelo que, durante décadas, estes pediram a renegociação do NAFTA ${ }^{208}$.

Desse modo, apesar de, em 2016, o desemprego nos EUA estar abaixo de 5\%, um índice bastante auspicioso, especialmente tendo em consideração o cenário de rescaldo da crise de 2008, a desacreditada candidatura de Donald Trump à presidência foi impulsionada por discursos que apontavam as políticas de livre comércio como responsáveis pelo colapso da indústria manufatureira americana, já que a atual dinâmica da economia daquele país gerava emprego em países como México e China às custas dos postos de trabalho domésticos e da depreciação dos salários dos americanos. Posto isso, ao concentrar-se nas regiões do país onde a recuperação desde a crise financeira não foi sentida, como no centro industrial de Detroit, Trump exitosamente destacou a taxa de desemprego e os níveis de criminalidade acima da média da cidade do motor para se apresentar como o antídoto ao declínio da produção dos $\mathrm{EUA}^{209}$ e transformou a promessa de reforma do comércio internacional num pilar fundamental em sua campanha eleitoral presidencial, garantindo-lhe votos de zonas industriais. Vencidas as eleições e passados apenas cinco meses da posse, o Congresso Americano foi intimado sobre a intenção do presidente de renegociar o NAFTA.

Após alguns meses de negociações ${ }^{210}$, em 30 de setembro de 2018 foi anunciada a substituição do NAFTA pelo Acordo Estados Unidos-México-Canadá (USMCA) para $1 .^{\circ}$ de janeiro de 2020 - na proposta é possível verificar que os direitos trabalhistas constam no corpo do texto principal (capítulo 23), cujo anexo 23-A, intitulado de "Representação dos trabalhadores na negociação coletiva no México"211, impõe àquele país uma série de dispositivos práticos de reforma da legislação trabalhista que o mesmo deve adotar como

\footnotetext{
${ }^{208}$ Universidade de Fortaleza. (2018). The United States-Mexico-Canada Agreement (USMCA): A summary. Unifor Research Department. Disponível em:

$<$ https://www.unifor.org/sites/default/files/attachments/usmca uniforanalysis oct2018 eng_0.pdf $>$. Acesso em: 10 jan. 2019.

${ }^{209}$ The Guardian. (2016). Trump's economic policies: protectionism, low taxes and coal mines. [on-line]. Disponível em:

$<$ https://www.theguardian.com/us-news/2016/nov/09/trumps-economic-policies-protectionism-low-taxesand-coal-mines $>$. Acesso em: 21 nov. 2018.

${ }^{210} \mathrm{~A}$ bem da verdade, os EUA apresentaram uma série de propostas linha-dura destinadas a garantir ganhos econômicos às custas do Canadá e do México sob a alegação de que a anterior relação comercial lhe era injusta e desvantajosa.

${ }^{211}$ Tradução nossa. "worker representation in collective bargaining in mexico" (Office of the United States Trade Representative. (2018). USMCA Text. [on-line]. Disponível em $<$ https://ustr.gov/sites/default/files/files/agreements/FTA/USMCA/Text/23 Labor.pdf $>$. Acesso em: 10 jan. 2019).
} 
condições de implementar o acordo e que, segundo um sindicato canadense, o tal anexo "pretende reformar o sistema corrupto de contratos de proteção do México"212.

Destarte, à despeito de todo o destaque que ganhou nos discursos proferidos pelo presidente Trump, sindicatos e ativistas, não é difícil perceber que os motores que movem as peças no âmbito do NAFTA/USMCA não são os direitos sociais, uma vez que, essencialmente, os direitos trabalhistas fundamentais estabelecidos no capítulo 23 do novo acordo refletem meramente os enunciados nas Declarações da OIT e os meios para implementar essas obrigações continuam, em regra, a depender das legislações nacionais, cuja exceção, conforme já exposto, restringe-se ao México, permitindo a alegação de que se trata muito mais de meio de neoprotecionismo por parte dos estadunidenses e canadenses do que de preocupação com o bem-estar dos trabalhadores mexicanos.

Neste ponto, vale trazer à baia as palavras de Stiglitz \& Chalton, para quem

[...] o NAFTA não era verdadeiramente um acordo de livre-comércio. [...] O NAFTA colocou o pesado sector subsidiado americano de agricultura comercial contra os produtores camponeses e quintas familiares mexicanas. [...] um quinto dos trabalhadores mexicanos estava empregado no setor agrícola e 75 por cento da pobreza mexicana encontrava-se nas áreas rurais. [...] quatro quintos da população rural do México viviam na pobreza, e mais de metade vivem em pobreza extrema ${ }^{213}$.

Nesta senda, insta, na sequência, atacar o discurso do dumping social no seio da União Europeia, posto que é no seu âmbito que alcança sua maior ressonância, impulsionada principalmente pelas mudanças carreadas na esteira do contínuo processo de expansão/integração europeu.

\subsubsection{O complexo contexto de expansão da União Europeia}

Entre as décadas de 1950 e 1970, a Europa ocidental, nomeadamente os países do Centro, Norte e Reino Unido, experimentaram um nível de desenvolvimento econômico e social sem precedentes que, num ambiente ainda incipiente da globalização, permitiu naqueles países o surgimento de uma consciência social e o envolvimento da sociedade civil no processo de formulação de políticas públicas, cujos frutos foram sistemas de segurança

\footnotetext{
${ }^{212}$ Tradução nossa. "This Annex intends to overhaul Mexico's corrupt protection contract system" (Universidade de Fortaleza, 2018, on-line).

${ }^{213}$ Stiglitz \& Charlton, 2009, p. 63.
} 
social, às instituições de representação de interesses e negociação coletiva baseadas no diálogo social, de modo que os resultados se refletiam nos altos níveis de coesão social e em serviços públicos de excelência, conjunto que fícou conhecido como "Modelo Social Europeu"214.

Todavia, com a crise do petróleo nos anos de 1970, a simbiose entre mercado e proteção social sofre os primeiros abalos mediante a forte desaceleração do crescimento econômico, prenunciando o fim do milagre econômico europeu que, de fato, logo se concretizou e se fez sentir através de aumentos das taxas de desemprego e a percepção de que as empresas europeias não dispunham do nível de competividade necessário para buscar seu espaço na emergente e ameaçadora arena do mercado global. Neste contexto, a União Europeia inicia seus ambiciosos projetos de integração/expansão com o lançamento do Mercado Único e os alagamentos à Sul (anos 1980) e à Leste $(\operatorname{anos} 2000)^{215}$.

Este projeto de expansão então é pensado sob influência do ordoliberalismo ou liberalismo ordeiro alemão ${ }^{216}$, isto é, a União Europeia se assume como uma economia social de mercado, caraterizada por impor uma dimensão social à economia e por forte atuação estatal na regulação e monitorização do mercado, visando garantir a livre concorrência sem descuidar da justiça social.

Em conformidade com o supramencionado, o Tratado de Funcionamento da União Europeia, notadamente no seu artigo $119 .^{\circ}$, permite constatar que o princípio norteador da "Política Económica e Monetária" da UE é o "mercado aberto e livre concorrência" ao que se associa ao artigo $3 .^{\circ}$ do TUE que, por sua vez, impõe a essa política econômica objetivos de cunho social, como "pleno emprego", “justiça e proteção social” e, destaque-se, "coesão económica, social e territorial”217.

\footnotetext{
${ }^{214}$ Bernaciak, 2012, pp. 18-19.

${ }^{215}$ Ibid., pp. 19-20.

${ }^{216}$ Alternativa alemã ao liberalismo "laissez faire" smithiano, também conhecida como "a terceira via", foi capitaneada pela "Escola de Friburgo", notadamente pelos professores Walter Eucken, Franz Böhm, Alexander Rüstow, Wilhelm Röpke e Alfred Müller-Armack. Trata-se da teoria por trás do "soziale Markwirtschaft" do chanceler Ludwig Erhard, culminado com o chamado "milagre económico alemão" pós-Segunda Guerra. Vide: Bonefeld, V. (2012). Freedom, Crisis and the Strong State: On German Ordoliberalism. British International Studies Association. [on-line]. Disponível em:

$<\underline{\text { https:} / / \text { www.google.pt/url? sa }=t \& r c t=j \& q=\& e s r c=s \& \text { source }=\text { web\&cd }=8 \& \text { cad }=\text { rja\&uact }=8 \& v e d=0 a h U K E w i}$ Zp ik5-

vYAhUCkRQKHRIMDIYQFghaMAc\&url=http\%3A\%2F\%2Fbisa.ac.uk\%2Findex.php\%3Foption\%3Dcom bisa \%26task\%3Ddownload paper\%26no html\%3D1\%26passed paper id\%3D137\&usg=AOvVaw3Q89cw RvtULwLHLAlLrAMu>. Acesso em: 22 jan. 2018.

${ }^{217}$ Quadros, F. (2015). Direito da União Européia: Direito Constitucional e Administrativo da União Européia. 3. ed. Coimbra: Almedina, pp. 149-151.
} 
Por conseguinte, ao contrário do NAFTA que adotou uma estratégia de cooperação via preservação da diversidade ${ }^{218}$, a unificação da Europa fora planeada visando harmonização econômica e social ascendente ${ }^{219}$, ou seja, pelo viés econômico, a livre concorrência iria promover o enriquecimento de todos os EM, permitindo aos estados mais atrasados adotarem os elevados padrões sociais implementados nos pioneiros; em outras palavras, o incremento da economia única deveria implicar num modelo social forte e coeso, benéfico a todos os países da comunidade. Em face dessa lógica em que o sistema econômico acaba por determinar o modelo social, os líderes europeus definiram a "livre circulação de pessoas, bens e serviços" como a base do projeto econômico comum, notadamente do seu mercado comum ${ }^{220}$.

Não obstante, os críticos afirmam que o modelo europeu conferiu primazia às liberdades econômicas e acabou por exacerbar o pensamento competitivo, culminando numa política geral de desregulamentação que não só deixou de assegurar uma maior coesão social e econômica, como, ao inverso, fragilizou os sistemas de proteção sociais dos Estadosmembros ${ }^{221}$, dando largada, na verdade, a uma "corrida ao fundo" (race to the botton) ${ }^{222}$.

Sendo assim, em contraste com o idealizado e apesar dos monumentais avanços no que tange a consolidação do mercado comum e da união monetária, a Europa ainda padece de coesão econômica e social, ou seja, na verdade, a União Europeia é uma "colcha de retalhos" composta por estados com estágios de desenvolvimento econômico e social bastante díspares ${ }^{223}$.

\footnotetext{
${ }^{218}$ Thorstensen, 1998.

${ }^{219}$ Bunescu, 2011.

${ }^{220}$ Neste intento, Porto (2017, p. 289) aclara que a União Europeia se constitui "não só uma união aduaneira e um mercado único, também um mercado comum, [...] caracterizada na sua essência ser um espaço em que deve haver liberdade de circulação dos fatores de produção e de prestação de serviços".

${ }^{221}$ Nas palavras de Moreira (2014, p. 75): “A integração do mercado interno foi em grande medida conseguida através da desregulamentação económica e social nacional ('integração negativa'), portanto em parte à custa dos direitos sociais, sem que em contrapartida se tivesse dado o reconhecimento e a proteção de tais direitos no plano da União ('integração positiva')".

${ }^{222}$ Cremers, J. EU economic freedoms and social dumping. In: Bernaciak, M. (2015). Market Expansion and Social Dumping in Europe. London: Routledge, pp. 173-190.

${ }^{223}$ Aqui cabe trazer à baia três ponderações de Porto (2017, op. cit., pp. 370-371) acerca do projeto de coesão econômica e social da União Europeia: "a primeira é a de que a teoria do equilíbrio automático, cuja lógica é indiscutível, assenta em pressupostos que na sua pureza não se verificarão na realidade"; "uma segunda consideração é a de que mesmo algo que venha a ser atingido a longo prazo pode não o ser a curto e médio prazos"; "por fim, em terceiro lugar há que saber se a tendência para o reequilíbrio, mesmo a longo prazo, se verifica só em grandes espaços - de um modo geral entre países - ou também entre espaços regionais [...], que importa igualmente aproximar, por razoes de todas as naturezas".
} 
Nesse contexto, o nível salarial e as prestações de segurança social praticadas nos países do Norte do continente europeu são bastante superiores quando comparados aos países do Sul e, sobretudo, aos do Leste e, apesar dos esforços dispendidos visando amenizar tais diferenças, a verdade é que só o nivelamento dos estágios de desenvolvimento econômico ${ }^{224}$ dos estados europeus é que vai permitir a equiparação dos níveis salariais e a viabilização de um ordenamento jurídico harmônico, em especial quanto aos direitos sociais e laborais, tudo para, enfim, conferir uma justa competição entre empresas no mercado comum, em coerência com a lógica que sempre esteve na base do projeto europeu, ou seja, com a economia a moldar o social.

Desse modo, em que pesem os ideais e valores do "Modelo Social Europeu", o maior atrativo da União Europeia é, de fato, o seu mercado comum, entretanto, o passe é custoso, nomeadamente para aqueles que também aderirem ao euro, pois, para se ter acesso a mercado e moeda comuns é preciso repassar o controle das políticas creditícias, monetárias e a da adaptação institucional para as instituições europeias em Bruxelas, Frankfurt, etc., ou seja, este é o preço que os aderentes pagam para que seus agentes econômicos possam ser livres para brigar pelo seu espaço no mercado comum e, com sorte, trazer divisas ao país, possibilitando a acumulação de capital indispensável ao próprio desenvolvimento económico e social.

Em suma, em termos de desenvolvimento, aos países da União Europeia se exige que renunciem a maior parte das políticas desenvolvimentistas como as alfandegárias, cambiais e de fomento para lhes oferecer moeda forte e acesso livre ao mercado comum, com vistas no desenvolvimento econômico de todos e, por conseguinte, maior coesão social no conjunto. À despeito disso, na prática ganha força um discurso político que enfatiza uma suposta ameaça que países mais pobres representa para os trabalhadores dos mais abastados.

É neste cenário que esse discurso do dumping social joga uma cortina de fumaça sobre o fato de que a política de integração da UE, mais tendenciosa aos processos de mercado do que à manutenção da regulação social, permite, por exemplo, que empresas multinacionais, baseadas principalmente em países ricos, organizem sua produção de uma forma a explorar os diferentes padrões sociais que resultam da já citada "colcha de retalhos"

\footnotetext{
${ }^{224}$ Nusdeo (2015, pp. 292-293) aponta como fatores essenciais ao processo de desenvolvimento econômico a "acumulação de capital, a evolução tecnológica e a disponibilidade de mercado consumidor"; na sequência, lista as principais políticas que um país pode dispor para tal fim como sendo a "política creditícia, a política monetária a adaptação institucional”.
} 
europeia. Esse mecanismo de competição baseada em preços que têm o condão de minar padrões de trabalho está abrangido por um fenômeno maior, um lenta mudança na organização do capitalismo na Europa conhecida como marketization, marquetização ou mercantilização ${ }^{225}$ e será abordado no item 2.5.

\subsubsection{A fobia aos canalizadores poloneses}

O "canalizador polonês", como uma alegoria de mão de obra barata, tornou-se um slogan do campo "não" francês durante o referendo sobre a Constituição da UE ${ }^{226}$. Como resultado, mediante alto comparecimento dos franceses às urnas, a proposta foi rejeitada por $55 \%$ dos eleitores, um golpe fatal para o projeto que precisaria ser ratificado por todos os 25 países membros 227 .

Mais recentemente os militantes pró-brexit acusavam os canalizadores poloneses, romenos, búlgaros e outros de ocuparem empregos dos trabalhadores britânicos e conclamavam os cidadãos do Reino Unido a deixarem de pagar o "bem-estar" dos imigrantes. Acontece que um estudo de 2014 realizado por economistas da University College London constatou que os migrantes de novos Estados-membros da UE, como a Polônia, contribuem com $£ 5$ bilhões a mais para a economia britânica do que recebem em "bem-estar"228.

O estereótipo do canalizador polonês é derivado das acusações de dumping social ocorridas no âmbito das propostas de diretivas visando regulamentar o trabalho destacado no contexto de expansão da União Europeia, conforme se verá a seguir.

\footnotetext{
${ }^{225}$ Greer, I. \& Hauptmeier, M. (2014). Social dumping as marketization: Management whipsawing in Europe's auto industry. Cornell University, ILR School. [on-line]. Disponível em:

$<$ https://digitalcommons.ilr.cornell.edu/articles/969/>. Acesso em: 04 fev. 2019.

${ }^{226}$ BBC News. (2005). 'Polish plumber' beckons French. [on-line]. Disponível em: $<$ http://news.bbc.co.uk/2/hi/europe/4115164.stm>. Acesso em: 04 fev. 2019.

${ }^{227}$ Insta lembrar que a Holanda também rejeitou a proposta (BBC News. (2005). French say firm 'No' to EU treaty. [on-line]. Disponível em: $<$ http://news.bbc.co.uk/2/hi/europe/4592243.stm $>$. Acesso em 04 de fevereiro de 2019).

${ }^{228}$ The Guardian. (2014). UK gains £20bn from European migrants, UCL economists reveal. [on-line]. Disponível em: $<$ https://www.theguardian.com/uk-news/2014/nov/05/eu-migrants-uk-gains-20bn-ucl-study $>$. Acesso em: 04 fev. 2019.
} 
2.3.2.1 O trabalho destacado e o canalizador polonês

Trabalho destacado no âmbito da prestação de serviços transfronteiriços é aquele em que o empregador envia o trabalhador a outro país visando realizar um serviço específico, ao final do qual é suposto retornar ao país de origem, ou seja, o trabalhador é deslocado temporariamente ao estrangeiro, cumpre seu ofício em nome do seu empregador e retorna ao país de residência. Não se confunde com imigração, posto que os destacados já possuem emprego e deslocam-se por tempo determinado "para executarem um trabalho, por conta de seu empregador, em virtude de um contrato já existente ${ }^{229 "}$.

Trata-se de fenômeno surgido no século XX diante da necessidade das primeiras empresas multinacionais de enviar seus altos funcionários de sua sede para o estrangeiro em vistas de atuar em filial ou em outra companhia do mesmo grupo e, a princípio, não despertou maiores preocupações quanto à sua regulamentação, dado que a prática era bastante restrita $^{230}$. Porém, com o avançar do processo de globalização, a expansão ao estrangeiro das atividades das empresas passou a ser regra de sobrevivência, além disso, as novas tecnologias de informação e os avanços na superação das barreiras ao comércio internacional, bem como as novas facilidades no que tange à mobilidade das pessoas, faz surgir uma nova dinâmica na economia mundial em que a inovação e a necessidade de cortar custos são regras básicas de sobrevivência. Nesta esteira, grandes, médias e pequenas empresas disputam um único mercado, o global, e o destacamento de trabalhadores é um dos instrumentos a serviço desse objetivo que, já agora, não se restringe aos executivos, mas a qualquer trabalhador.

A sequência de dois momentos históricos na Europa fortalece o discurso do dumping social e sua associação à questão do destacamento de trabalhadores: o primeiro foi o alargamento ao Sul, com ingresso de Grécia, Espanha e Portugal na União Europeia no final da década de 1970 e início da de 1980, enquanto o segundo foi a expansão ao Leste iniciada em 2004.

${ }^{229}$ Gomes, J. (2007). Direito do Trabalho. I. Coimbra, pp. 61 -62 apud Laurino, S. F. L. (2013). Destacamento de Trabalhadores: Dumping social e os desafios à afirmação do espaço social europeu. São Paulo: LTr, p. 57. ${ }^{230}$ Nascimento, A. P. \& Anacoreta, J. P. (2007). Destacamento de trabalhadores. In: Foro de Actualidad, vol. 18, p. 120. Disponível em: $<$ http://www.uria.com/documentos/publicaciones/1812/documento/articuloUM.pdf?id=3175>. Acesso em: 31 jan. 2019. 
Temendo a intensificação da migração laboral intra-UE, os antigos membros, com destaque para a Alemanha, decidiram limitar temporariamente o acesso dos europeus do Sul a seus mercados de trabalho em sete anos, ou seja, aos trabalhadores desses países não era permitido buscar emprego na Alemanha, França e outros, contudo, nenhuma limitação fora imposta a que empresas gregas, espanholas ou portuguesas pudessem prestar serviços nos demais membros da UE. Na sequência, deu-se que os europeus do Sul foram escolhidos por empresas sediadas em seus países para prestarem serviços nas demais nações europeias e, para tanto, eram remunerados conforme as regras do seu país de origem ${ }^{231}$. Não tardou para que os governos dos países receptores dessa mão de obra, bem como seus sindicatos e prestadores de serviços domésticos, passassem a criticar a "estratégia" econômica das empresas do Sul europeu como "concorrência injusta" ou "desleal" e "dumping social" 232 .

Em outro momento, se deu a expansão ao Leste, um processo que resultaria num aumento em $28 \%$ da população da UE, ao passo que o PIB do bloco só seria incrementado a $4 \%{ }^{233}$, o que levou um ressurgir do brado de resistência entoado por políticos e sindicatos contra o suposto dumping social, caricaturado na figura do encanador polonês. Nesse contexto, Bernaciak destaca três legítimas preocupações que, por complexas e plausíveis, contrastam com a simplista, irreal e perigosa abordagem presente nos populistas discursos do dumping social, quais sejam: o padrão salarial mais baixo e a falta de regulamentação trabalhista a servir de ímã para investimentos diretos estrangeiros, por conseguinte, no deslocamento de empresas do Oeste para Leste; a migração laboral de Leste para Oeste, especialmente em setores que demandam mão de obra intensiva, como construção civil, agricultura, etc.; e um possível impacto negativo nos sistemas de segurança social dos antigos membros ${ }^{234}$.

Acontece que a União Europeia tem competência jus-laboral limitada pelo princípio da subsidiariedade. Nesta área, o artigo 137. ${ }^{\circ}$ do Tratado de Roma lhe permite apenas apoiar e complementar as ações dos Estados-membros via introdução de diretivas com prescrições mínimas e progressivamente aplicáveis visando, de uma forma geral, a melhoria das condições de trabalho e dos sistemas de segurança social.

\footnotetext{
${ }^{231}$ Bernaciak, 2012, pp. 10-12.

${ }^{232}$ Ibid.

${ }^{233}$ Ibid

${ }^{234}$ Ibid., pp. 11-13.
} 
Isto posto, apesar de o trabalho destacado perfazer somente $0,4 \%$ do total dos trabalhadores na Europa, fato é que o número de trabalhadores destacados na UE aumentou $41 \%$ de 2010 a $2015^{235}$, chamando atenção ainda o fato de que tais números se concentram em determinados setores da economia, com ênfase na construção civil $(41,5 \%$ do total dos trabalhadores destacados), na indústria transformadora (24,6\% do total dos trabalhadores destacados) e nos serviços a empresas (10,4\% do total dos trabalhadores destacados $)^{236}$.

De início, às situações de destacamento de trabalhadores eram aplicadas as tratativas contidas na Convenção de Roma, nomeadamente as normas de conflito quanto à legislação aplicada às relações contratuais trabalhistas plurilocalizadas ${ }^{237}$, cujos critérios para delimitação das leis a serem aplicadas eram: em primeiro lugar, a escolha acordada pelas partes; na ausência de qualquer ajuste prévio, deveriam prevalecer as regrais legais dispostas no ordenamento jurídico do país onde o trabalhador presta seu trabalho de forma habitual; e, de modo excepcional, poderia aplicar-se "a lei de outro país com o qual o contrato apresente uma conexão mais estreita" ${ }^{238}$. Alegando-se que:

[...] esse regime abria as portas a que empresas situadas em países com mão de obra mais barata pudessem levar seus trabalhadores a prestar trabalhos noutros países com economias mais desenvolvidas [...], situação que traduzir-se-ia numa forma de concorrência desleal, uma vez que a vantagem competitiva era alcançada às custas de pagamento injustificado de salários inferiores aos prestados no mercado receptor $[\ldots]^{239}$.

Em 16 de dezembro de 1996, a Comissão Europeia tratou de regular tais situações por meio da Diretiva 96/71/CE. Nesse diapasão, a supramencionada diretiva reconheceu a complexidade da questão e fez clara opção pela coordenação dos Estados-membros em

\footnotetext{
${ }^{235}$ European Comission. (2016). Revisão relativa ao destacamento de trabalhadores - perguntas frequentes. Estrasburgo, 8 de março de 2016. Disponível em: <http://europa.eu/rapid/press-release MEMO-16467 pt.htm $>$. Acesso em: 17 jan. 2018.

${ }^{236}$ Parlamento Europeu. (2016). Relatório sobre dumping social na União Europeia. Comissão do Emprego e dos Assuntos Sociais, Relator: Guillaume Balas. Disponível em:

$<$ http://www.europarl.europa.eu/sides/getDoc.do?pubRef=-//EP//TEXT+REPORT+A8-20160255+0+DOC+XML+V0//PT>. Acesso em: 17 jan. 2018.

${ }^{237}$ Cf. Parlamento Europeu. (1957). Tratado de Roma (CEE), arts. 6. ${ }^{\circ}$, n. ${ }^{\circ} 1$ e n. ${ }^{\circ}$ 2. Disponível em: $<$ http://www.europarl.europa.eu/about-parliament/pt/in-the-past/the-parliament-and-the-treaties/treaty-ofrome $>$. Acesso em: 17 jan. 2018.

${ }^{238}$ Nascimento \& Anacoreta, 2007, p. 121.

${ }^{239}$ Ibid.
} 
detrimento da alternativa de tentar forçar uma harmonização legislativa de realidades econômicas, sociais e jurídicas bastante diferentes entre $\mathrm{si}^{240}$.

Pode-se afirmar que a diretiva 96/71/CE tinha por encargo colmatar dois pontos sensíveis no que tange à questão do destacamento transnacional e temporário de trabalhadores na Europa: prevenir distorções na concorrência, garantindo a liberdade de prestação de serviços no mercado comum, e proteger os direitos básicos dos trabalhadores destacados.

Desta feita, logo no artigo $2 .^{\circ}$, é definido o trabalho destacado como sendo aquele em que "o trabalhador que, por um período limitado, trabalhe no território de um Estadomembro diferente do Estado onde habitualmente exerce a sua atividade”. Já o n. ${ }^{\circ} 1$ do artigo 3. ${ }^{\circ}$ trata de estabelecer um standard, não exaustivo, de proteção aos direitos laborais dos trabalhadores destacados, chamado de "núcleo duro"241, em que os Estados-membros receptores de mão de obra destacada deverão garantir aos trabalhadores, seja por "disposições legislativas, regulamentares ou administrativas e/ou por convenções colectivas ou decisões arbitrais declaradas" 242 como: períodos máximos de trabalho e períodos mínimos de descanso; feriados anuais pagos; taxas mínimas de remuneração, incluindo as horas extras; condições para a contratação de trabalhadores, em particular a oferta de trabalhadores por empresas de trabalho temporário; saúde, segurança e higiene no trabalho; medidas de proteção nos termos e condições de emprego de mulheres grávidas ou que tenham dado à luz recentemente; e igualdade de tratamento entre homens e mulheres e outras disposições relativas à não discriminação ${ }^{243}$.

\footnotetext{
${ }^{240}$ Gava, 2008, pp. 222-224.

241 “a) Períodos máximos de trabalho e períodos mínimos de descanso;

b) Duração mínima das férias anuais remuneradas;

c) Remunerações salariais mínimas, incluindo as bonificações relativas a horas extraordinárias; a presente alínea não se aplica aos regimes complementares voluntários de reforma;

d) Condições de disponibilização dos trabalhadores, nomeadamente por empresas de trabalho temporário;

e) Segurança, saúde e higiene no trabalho;

f) Medidas de protecção aplicáveis às condições de trabalho e emprego das mulheres grávidas e das puérperas, das crianças e dos jovens;

g) Igualdade de tratamento entre homens e mulheres, bem como outras disposições em matéria de não discriminação" (European Union Law. (1997). Directiva 96/71/CE do Parlamento Europeu e do Conselho de 16 de Dezembro de 1996 relativa ao destacamento de trabalhadores no âmbito de uma prestação de serviços. Jornal Oficial n n $^{\mathrm{L}} 018$ de 21/01/1997, pp. 0001-0006. Disponível em:

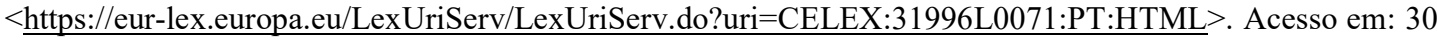
nov. 2018).

${ }^{242}$ Parlamento Europeu. (2017). Understanding social dumping in the European Union. Disponível em: $<$ http://www.europarl.europa.eu/thinktank/en/document.html?reference=EPRS_BRI(2017)599353>. Acesso em: 30 nov. 2018

${ }^{243}$ Parlamento Europeu, 2017.
} 
Em outro tempo, partindo do fato de que os serviços representam $70 \%$ do emprego na Europa e que o seu desimpedimento aumentaria o emprego e o PIB da União Europeia, Frits Bolkestein, comissário europeu para o mercado interno durante a presidência de Romano Prodi, capitaneou um projeto de diretiva apresentado pela Comissão Europeia em fevereiro de 2004, sobre "Os Serviços e o Mercado Interno", tendo por base o "princípio do país de origem (PPO)", ou seja, visando que o prestador de serviços estivesse vinculado apenas ao sistema jurídico do país em que estava sediado ${ }^{244}$. O projeto, que ficou conhecido como "Diretiva Bolkestein", foi tomado por grande polêmica ao passo que seus detratores argumentavam que a aprovação do projeto como originalmente apresentado à UE estaria autorizando o dumping social, isto é, a concorrência desleal baseada no cerceamento de direitos básicos dos trabalhadores ${ }^{245}$.

A polêmica do canalizador polonês se origina quando Frits Bolkestein, na tentativa de destravar o mercado único de serviços na UE, por meio de uma série de declarações durante uma conferência de imprensa, mencionou que estaria contratando um canalizador polonês para realizar trabalhos manuais em sua segunda casa no Norte da França; imediatamente, surge a anedota que vem simbolizando coloquialmente o medo da ameaça de mão de obra barata do Leste europeu e, portanto, o medo do dumping social ${ }^{246}$.

Destarte, mediante massiva pressão exercida por sindicatos e governos dos países hegemônicos do bloco, o Parlamento Europeu foi forçado a abandonar o "princípio do país de origem (PPO)" como vetor da futura diretiva e, em 12 de dezembro de 2006, foi aprovada a Diretiva 2006/123/CE, sem qualquer disposição direta ao destacamento de trabalhadores, justamente para que em tais situações permanecessem com a aplicação da Diretiva 96/71.

\footnotetext{
${ }^{244}$ Ramalho, M. R. P. A Dir. 2006/123/CE no Mercado Interno (Diretiva Bolkenstein) e a Harmonização Comunitária no Domínio da Segurança Social e do Direito do Trabalho. Algumas notas. In: Estudos em Homenagem ao Professor Doutor Paulo de Pitta Cunha. I, cit. p. 648 apud Laurino, 2013, p. 66.

${ }^{245}$ Ibid.

${ }^{246}$ Linos, C. [s.n.]. Phobia of polish plumbers: evaluating the prevalence and effects of social dumping in sweden in the context of european integration. Paper apresentado no âmbito da disciplina Economics of European Integrations na Harvard University, p. 04. Disponível em: $<$ http://elnd.gr/index.php/gr/\%CE $\%$ B5\%CF $\% 81 \% \mathrm{CE} \% \mathrm{~B} 5 \% \mathrm{CF} \% 85 \% \mathrm{CE} \% \mathrm{BD} \% \mathrm{CE} \% \mathrm{~B} 7 \% \mathrm{CF} \% 84 \% \mathrm{CE} \% \mathrm{~B} 9$ $\% \mathrm{CE} \% \mathrm{BA} \% \mathrm{CE} \% \mathrm{AE}-$

\%CE $\%$ B $4 \% \mathrm{CF} \% 81 \% \mathrm{CE} \% \mathrm{~B} 1 \% \mathrm{CF} \% 83 \% \mathrm{CF} \% 84 \% \mathrm{CE} \% \mathrm{~B} 7 \% \mathrm{CF} \% 81 \% \mathrm{CE} \% \mathrm{~B} 9 \% \mathrm{CF} \% 8 \mathrm{C} \% \mathrm{CF} \% 84 \% \mathrm{CE} \% \mathrm{~B}$ 7\%CF $\% 84 \% \mathrm{CE} \% \mathrm{~B} 1 / \% \mathrm{CE} \% \mathrm{~B} 6 \% \mathrm{CE} \% \mathrm{~B} 7 \% \mathrm{CF} \% 84 \% \mathrm{CE} \% \mathrm{AE} \% \mathrm{CE} \% \mathrm{BC} \% \mathrm{CE} \% \mathrm{~B} 1 \% \mathrm{CF} \% 84 \% \mathrm{CE} \% \mathrm{~B} 1-$ $\% \mathrm{CE} \% \mathrm{~B} 5 \% \mathrm{CF} \% 85 \% \mathrm{CF} \% 81 \% \mathrm{CF} \% 89 \% \mathrm{CF} \% 80 \% \mathrm{CE} \% \mathrm{~B} 1 \% \mathrm{CF} \% 8 \mathrm{~A} \% \mathrm{CE} \% \mathrm{BA} \% \mathrm{CE} \% \mathrm{AE} \% \mathrm{CF} \% 82-$ $\% \mathrm{CE} \% \mathrm{AD} \% \mathrm{CE} \% \mathrm{BD} \% \mathrm{CF} \% 89 \% \mathrm{CF} \% 83 \% \mathrm{CE} \% \mathrm{~B} 7 \% \mathrm{CF} \% 82 /$ item/download $/ 3$ f80349eb0b5c414ee67e400a e2eb89ee>. Acesso em: 16 jan. 2019.
} 
Na sequência, em 15 de maio de 2014, foi publicada a Diretiva 2014/67/UE do Parlamento Europeu e do Conselho, também conhecida por "diretiva de execução", buscando combater possíveis "práticas abusivas e evasão às regras aplicáveis" através do intercâmbio de informações entre os Estados-membros ${ }^{247}$.

Ocorre que as queixas não cessaram, Estados e sindicatos, com destaque para a França, ante a incapacidade de competir com os serviços mais baratos provenientes dos EM em estágio inferior de desenvolvimento econômico, pressionam as autoridades europeias a enrijecer ainda mais os termos da regulamentação acerca do destacamento de trabalhadores, para, ao final, forçar a perda de uma das poucas vantagens comparativas que as empresas sediadas nos países menos desenvolvidos detêm, de modo a preservar seus postos de trabalhos à custa de inviabilizar a atuação daquelas empresas nos países hegemônicos europeus e, consequentemente, travar o processo de coesão econômico-social que é a própria razão da existência do mercado comum europeu.

Nessa perspectiva, “em 08 de março de 2016, foi apresentada pela Comissão uma proposta de revisão da diretiva 96/71, visando, em especial, a questão dos rendimentos dos trabalhadores destacados, sob abrigo do chamado "princípio do salário igual por trabalho igual no mesmo lugar"248, assim, a remuneração do trabalhador destacado deveria ser igual ao do trabalhador nacional, portanto, não apenas composta pelas taxas mínimas de remuneração, mas, também, de outros elementos, como bônus ou subsídios e os Estadosmembros deverão especificar os diferentes elementos constitutivos da remuneração no seu território. Após o protocolo sobre a aplicação dos princípios da subsidiariedade e da proporcionalidade, 11 parlamentos nacionais apresentaram um parecer fundamentado. Em 20 de julho de 2016, a Comissão Europeia concluiu que a proposta de revisão da directiva não constituía uma violação do princípio da subsidiariedade e decidiu mantê-la ${ }^{249}$.

Por sua vez, o Parlamento Europeu, em 14 de setembro de 2016, tomou para si o discurso do dumping social e adotou uma resolução prevendo uma série de ações visando:

[...] assegurar condições de concorrência equitativas, uma concorrência leal e a assistência mútua entre os Estados-membros", através da "cooperação

\footnotetext{
${ }^{247}$ A diretiva de execução tratou de definir os elementos factuais indispensáveis para distinguir as situações a serem classificadas como destacamento de trabalhadores daquelas fraudulentas, bem como tratou de viabilizar meios para maior e melhor integração administrativa entre os organismos dos Estados-membros, via IMI (Sistema de Informação do Mercado Interno) (European Comission, 2016).

${ }^{248}$ Ibid.

${ }^{249}$ Parlamento Europeu, 2017.
} 
transfronteiriça e coordenação entre os Estados-membros da UE; superação das lacunas de regulamentação na aplicação dos princípios da igualdade de remuneração e da proteção social igualitária; do combate ao dumping social para trabalhadores no sector dos transportes, por exemplo, através de um maior controlo da aplicação das regras relativas ao tempo de trabalho e tempo de repouso no sector dos transportes rodoviários, revendo as condições de trabalho nos serviços aéreos e de navegação, bem como através de a criação de uma Agência Europeia dos Transportes Rodoviários; e a promoção da convergência social, entre outras coisas, através de medidas específicas para ajudar as mulheres afetadas pelo dumping social; encorajando o respeito e a promoção da negociação coletiva; e controlando ainda mais as agências temporárias que enviam trabalhadores domésticos para outros Estados-membros ${ }^{250}$.

O Parlamento adotou ainda resoluções e decisões sobre as condições de trabalho dos trabalhadores dos transportes, como:

A Diretiva 2013/54/UE do Parlamento Europeu e do Conselho, de 20 de novembro de 2013, relativa a determinadas responsabilidades do Estado de bandeira pelo cumprimento e execução do Acordo Marítimo. Convenção do Trabalho, 2006. Com esta diretiva, o Parlamento pretende aproximar a Convenção do Trabalho Marítimo da legislação da UE, com o objetivo de reduzir o dumping social para os marítimos $^{251}$.

\subsubsection{A jurisprudência do TJUE sobre trabalho destacado}

Em contraste com a Comissão e o Parlamento que vêm cedendo às pressões que clamam por uma guinada do projeto europeu, o Tribunal de Justiça da União Europeia segue fiel ao guião ordoliberal original, ou seja, tentando equalizar os interesses econômicos e sociais, contudo, quando seus julgados dizem respeito à questão do destacamento de trabalhadores, as frequentes discussões no âmbito do TJUE, via "reenvio prejudicial", são bastante polêmicas, pelo que seguem apertadas sínteses de jurisprudências selecionadas com fito de se perceber a evolução do tema junto à corte europeia.

\subsection{Caso Rush Portuguesa: Processo c-113/89, acórdão dia 27 de março de 1990}

No final da década de 1980, a empresa de construção civil portuguesa "Rush Portuguesa Lda" fora contratada por uma empresa francesa para prestar determinados

\footnotetext{
${ }^{250}$ Parlamento Europeu, 2017.

${ }^{251}$ Ibid.
} 
serviços, em sede de "subempreitada", em diferentes estaleiros do "TGV Atlantique" na França. Para tanto, a sociedade empresarial destacou de Portugal para França um determinado número de trabalhadores de nacionalidade lusitana que, por sua vez, voltaram para Portugal logo após a conclusão dos serviços contratados ${ }^{252}$.

Sob argumento de que a situação supra exposta iria impor "risco ao mercado de trabalho da França", a autoridade francesa exigiu da empresa portuguesa "o pagamento de uma contribuição especial decorrente da violação de uma regra do Código de Trabalho da França, pela qual apenas o organismo nacional de imigração poderia recrutar trabalhadores estrangeiros" 253 .

Em conclusão ao acórdão em juízo de reenvio prejudicial, o Tribunal de Justiça retoma os princípios fundantes da União Europeia ao determinar que:

Os artigos $59 .^{\circ}$ e $60 .^{\circ}$ do Tratado CEE e os artigos $215 .^{\circ}$ e $216 .^{\circ}$ do acto de adesão do Reino de Espanha e da República Portuguesa devem ser interpretados no sentido de que uma empresa estabelecida em Portugal, que efectua prestações de serviços no sector da construção e obras públicas noutro Estado-membro, pode deslocar-se com o seu pessoal próprio, trazido de Portugal, pelo período de duração das obras em causa. Em tal caso, as autoridades do Estado-membro, no território do qual devem ser realizados os trabalhos, não podem impor ao prestador de serviços condições que respeitem à contratação de mão de obra no local ou à obtenção de uma autorização de trabalho para o pessoal português ${ }^{254}$.

\subsection{Caso Portugália: Processo C-164/99, acórdão de 24 de janeiro de 2002}

Sociedade empresária de Portugal, especializada em prestação de serviços no âmbito da construção civil, enviou trabalhadores portugueses à Alemanha para realizar trabalhos de construção. De acordo com a lei alemã sobre o destacamento de trabalhadores, "certos acordos coletivos no setor de construção que têm uma aplicação geral vinculativa

\footnotetext{
${ }^{252}$ Tribunal de Justiça da União Europeia. (1990b). Conclusões do Advogado-Geral Walter Van Gerven: apresentadas em 7 de março de 1990. Disponível em: $<$ http://curia.europa.eu/juris/showPdf.jsf;jsessionid=9ea7d0f130deb88764f09ce84d9cb4d8c5b4bc437c2a.e34 KaxiLc3eQc40LaxqMbN4Pb30Oe0?text $=\&$ docid $=96648 \&$ pageIndex $=0$ \&doclang $=$ PT\&mode $=1$ st \&dir $=$ \&occ $=$ first\&part=1\&cid=403378>. Acesso em: $21 \mathrm{fev} .2018$.

${ }^{253}$ Laurino, 2013, pp. 69-70.

${ }^{254}$ Tribunal de Justiça da União Europeia (1990a). Acórdão do Tribunal (Sexta secção). Processo n. ${ }^{\circ}$ C-113/89. Disponível em:

$<$ http://curia.europa.eu/juris/showPdf.jsf;jsessionid=9ea7d0f130deb88764f09ce84d9cb4d8c5b4bc437c2a.e34 $\underline{\text { KaxiLc3eQc40LaxqMbN4Pb30Oe0 } 2 \text { text }=\& \text { docid }=96686 \& \text { pageIndex }=0 \& \text { doclang }=P T \& \text { mode }=1 \text { st\&dir }=\& \text { occ }}$ $=$ first\&part=1\&cid=403378>. Acesso em: 21 fev. 2018 .
} 
foram estendidos para cobrir os empregadores que têm seu assento no exterior e seus trabalhadores destacados na Alemanha, na medida em que estabeleceram um salário mínimo"255.

Dessa forma, a empresa portuguesa foi compelida pela autoridade administrativa alemã a pagar diferenças salariais a seus obreiros visando atingir o salário mínimo negociado entre empresas e sindicatos alemães. Em sede de reenvio prejudicial, o TJUE concluiu que:

Um Estado-membro de acolhimento aos prestadores de serviços estabelecidos noutro Estado-membro da regulamentação nacional que prevê o salário mínimo é compatível com os artigos $59 .^{\circ}$ do Tratado CE (que passou, após alteração, a artigo $49 .^{\circ} \mathrm{CE}$ ) e $60 .^{\circ}$ do Tratado $\mathrm{CE}$ (actual artigo $50 .^{\circ} \mathrm{CE}$ ) $[\ldots]$.

Contudo, acrescenta-se:

O facto de um empresário nacional poder praticar um salário inferior ao mínimo previsto numa convenção colectiva declarada de aplicação geral, através da celebração de um acordo colectivo de empresa, enquanto um empresário estabelecido noutro Estado-membro não pode fazê-lo, constitui uma restrição injustificada à livre prestação de serviços ${ }^{256}$.

2.3.2.2.3 Caso Laval: Processo C-341/05, acórdão de 18 de dezembro de 2007

Trata-se de litígio que opôs a Laval un Partneri Ltd, construtora letã que venceu um certame que teve por objeto a construção de uma escola na cidade de Vexholm, na Suécia, mas que se viu pressionada por vários sindicatos locais (sindicato sueco dos trabalhadores do sector da construção e das obras públicas, e sindicato sueco dos eletricistas) a subscrever convenção coletiva relativa à construção civil na Suécia ${ }^{257}$.

Diante do quadro, a empresa letã argumentou que seus trabalhadores já estavam protegidos por instrumento coletivo semelhante, contudo, celebrado na Letônia. As organizações sindicais reagiram via ação coletiva de bloqueio dos trabalhos em curso, impedindo a entrada de trabalhadores e a entrega de mercadoria no canteiro da obra ${ }^{258}$.

\footnotetext{
${ }^{255}$ British Institute of International and Comparative Law. (2002). Opinion of Advocate General Mischo.

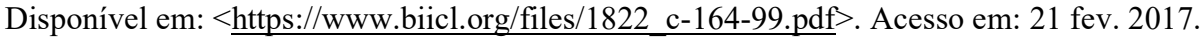

${ }^{256}$ European Union Law. (2006). Acórdão do Tribunal de Justiça (Primeira Secção). Processo n. ${ }^{\circ}$ C-244/04. Disponível em: $<$ http://eur-lex.europa.eu/legal-content/PT/TXT/?uri=CELEX:62004CJ0244>. Acesso em: 21 fev. 2017.

${ }^{257}$ Ibid. Cf. Conclusões do Advogado-Geral Paolo Mengozzi apresentadas em 23 de maio de 2007.

${ }^{258}$ Laurino, 2013, p.78.
} 
A situação se agravou quando outros sindicatos aderiram ao movimento visando boicotar todas as obras da Laval na Suécia, fato que motivou o pedido de rescisão do contrato por parte do município de Vaxholm, tudo culminando com a falência da empresa letã ${ }^{259}$.

No acórdão de 18 de dezembro de 2007, o TJUE assevera que o artigo $3 .^{\circ}$ da Diretiva 96/71, garante aos trabalhadores transnacionais determinadas condições como salário mínimo igual ao praticado pelo país receptor, desde que estejam dispostas por "lei, normas administrativas, decisões arbitrais ou convenções coletivas de aplicação geral” ${ }^{260}$.

O TJUE reconheceu que a atitude dos sindicatos em forçar a negociação "caso a caso" sugere uma situação de incontornável "incerteza jurídica" que, em última análise, implica em ofensa direta aos artigos 43. ${ }^{\circ}$ (liberdade de estabelecimento) e $49 .^{\circ}$ (liberdade de prestação de serviços) do Tratado de Roma, deixando claro que os preceitos carreados pela Diretiva 96/71/CE devem ser interpretados sempre levando em consideração o preceito fundamental da livre prestação de serviços no âmbito do mercado único europeu, cabendo uma interpretação restritiva no que diz respeito às obrigações impostas às empresas que destacam seus trabalhadores, sendo obrigatório apenas o chamado "núcleo duro".

2.3.2.2.4 Caso Elektrobudowa: Processo C-396/13, acórdão de 12 de fevereiro de 2015

No cumprimento de contrato, a empresa polonesa Elektrobudowa Spółka Akcyjna enviou colaboradores para a Finlândia para prestarem serviços temporários em uma central nuclear. O direito finlandês permite que convenções coletivas de aplicação geral definam múltiplos elementos para compor o salário mínimo para determinada categoria de trabalhador. Este ordenamento, contrariamente ao ordenamento polonês, também admite que o sindicato cobre créditos trabalhistas via cessão de direitos ${ }^{261}$.

No caso em tela, houve pedido intentado pelo sindicato finlandês, chamado Satakunnan käräjäoikeus, relativamente a créditos salariais resultantes de relações laborais

\footnotetext{
${ }^{259}$ Tribunal de Justiça da União Europeia. (2007). Acórdão do Tribunal de Justiça (Grande Secção). Disponível em: $<\underline{\text { http://curia.europa.eu/juris/liste.jsf?language }=\mathrm{pt \& num}=\mathrm{C}-341 / 05>}>$. Acesso em: 22 fev. 2018. Cf. Ponto 38 do acórdão.

${ }^{260}$ Laurino, 2013, p. 79; Tribunal de Justiça da União Europeia, 2007. Cf. pontos 64 e 65 do acórdão.

${ }^{261}$ Tribunal de Justiça da União Europeia. (2014). Conclusões do Advogado-Geral Nils Wahl: apresentadas em 18 de setembro de 2014. Disponível em:

$<$ http://curia.europa.eu/juris/document/document.jsf?text=\&docid=157856\&pageIndex=0\&doclang=PT\&mo $\mathrm{de}=1$ st\&dir $=\&$ occ $=$ first\&part $=1 \& \mathrm{cid}=426162>$. Acesso em: 22 fev. 2018.
} 
via cessão de direitos por parte dos trabalhadores poloneses que, por sua vez, fora rejeitado pela empresa polonesa.

Para tanto, em sede de reenvio, foram submetidas ao TJUE duas questões: legitimidade do sindicato finlandês em cobrar créditos trabalhistas via cessão, vez que é prática permitida pelo direito finlandês, mas vetada pelo ornamento jurídico polaco; e definição dos elementos que compõem o conceito de "remunerações salariais mínimas" para efeitos de destacamento de trabalhadores, ou seja, no âmbito da Diretiva 96/71/CE.

Em conclusão, o Tribunal Europeu, para a primeira questão, entendeu que: "a regulamentação do Estado-membro da sede da empresa que destacou trabalhadores para o território de outro Estado-membro, nos termos da qual a cessão de créditos resultantes de relações laborais é proibida" não pode:

[...] obstar a que um sindicato [...] intente uma ação num órgão jurisdicional do segundo Estado-membro, onde o trabalho é executado, para cobrar, em benefício dos trabalhadores destacados, créditos salariais relativos ao salário mínimo, na acepção da Diretiva 96/71, e que lhe foram cedidos, sendo essa cessão conforme ao direito em vigor nesse último Estado-membro ${ }^{262}$.

No tocante ao segundo questionamento, foi decidido que o salário mínimo pode ser "fixado à hora e/ou à tarefa" segundo a categoria salarial dos trabalhadores, bastando observar que as tais regras de fixação da remuneração sejam "vinculativas e transparentes"; as ajudas de custo diárias devem ser consideradas parte do salário mínimo; uma compensação pelo tempo de deslocação superiores a uma hora deve ser considerada parte do salário mínimo dos trabalhadores; mas "o pagamento do alojamento desses trabalhadores não deve ser considerado um elemento do seu salário mínimo" e que "vales de refeição entregues aos referidos trabalhadores não devem ser considerados parte do seu salário mínimo"263.

\footnotetext{
${ }^{262}$ Tribunal de Justiça da União Europeia. (2015). Acórdão do Tribunal de Justiça (Primeira Secção). Processo $n .{ }^{\circ} \mathrm{C}-396 / 13$. Disponível em:

$<$ http://curia.europa.eu/juris/document/document.jsf?text $=\&$ docid $=162247 \&$ pageIndex $=0 \&$ doclang $=\mathrm{PT} \& \mathrm{mo}$ $\mathrm{de}=1$ st\&dir $=\& o c c=$ first $\&$ part $=1 \& \mathrm{cid}=202425>$. Acesso em: 25 fev. 2018 .

${ }^{263} \mathrm{Ob}$. Cit.
} 
2.3.2.3 O destacamento de trabalhadores na Europa e o discurso do dumping social

Tendo em vista que o presente trabalho, por sua natureza, não pretende esgotar o assunto, passará a utilizar a questão dos "rendimentos laborais" como arquétipo das polêmicas envolvendo o destacamento de trabalhadores na União Europeia.

Dito isto, e conforme já supra exposto, através da diretiva 96/71, um Estadomembro pode exigir de empresa sediada em outro EM, que observe o salário mínimo válido para aquele território em que seu empregado esteja destacado, entretanto, a interpretação majoritária indica que as empresas que destacam trabalhadores para outros países devem observar as tabelas salariais mínimas do país receptor da mão de obra (definida por lei, convenção coletiva, etc.), o que poderia permitir que, por exemplo, em um mesmo canteiro de obras pudesse se verificar trabalhadores exercendo labor semelhante com remuneração distinta.

Aqui, insta retornar à definição de "destacamento de trabalhadores" para relembrar a "temporariedade" como seu elemento intrínseco, isto é, o trabalhador destacado, em regra, vai retornar ao país de origem, lá é que reside, lá é que mantém suas despesas cotidianas e, naturalmente, o custo de vida em países ao Leste e ao Sul da Europa é bastante inferior àquele dos países ao Norte e Centro. Ao pagar um salário justo ao nível do país de origem, a empresa prestadora de serviços irá ser justa com seu colaborador e ainda poderá fazer proveito de uma das poucas vantagens comparativas que lhe está à disposição, pois, além de deter, em geral, desvantagens no que tange ao nível tecnológico, qualificação da mão de obra, etc., deve-se ter em conta que o processo de destacar pessoas tem, em si, um custo elevado.

Ao tentar impor uma igualdade salarial rígida, não estar-se-á fazendo justiça, por exemplo, ao trabalhador letão, porque este não irá prestar mais serviços fora da Letônia; o resultado prático de todo este processo será, na verdade, a preservação de alguns empregos de franceses às custas de vários letões desempregados, além do enfraquecimento do mercado comum e da diminuição do volume de riqueza produzida.

Conforme foi possível perceber, a questão do destacamento de trabalhadores tem centralidade nos discursos do dumping social no âmbito da União Europeia, especialmente em se tratando do mercado único, contudo, na Europa, tal questão vai além dos discursos populistas que pressionam os entes políticos e prejudicam os agentes econômicos. À vista 
disso, percebe-se o Conselho e o Parlamento europeus mais suscetíveis às pressões populistas, dispondo-se a rever a questão do destacamento temporário de trabalhadores sempre que afrontados, fato que culmina com o enfraquecimento do ideal de liberdade na prestação de serviços que se constitui num dos pilares que dão sustentação ao mercado único e, por conseguinte, ao projeto europeu como um todo. Em outra toada, a atuação do Tribunal de Justiça da União Europeia parece se mostrar equilibrada, conforme demonstram os casos supra carreados, não cedendo às pressões advindas do discurso do dumping social.

Posto isso, faz-se necessário afastar o juízo de que os países europeus com menor grau de desenvolvimento econômico estão, propositalmente, minando os direitos sociais dos seus trabalhadores para ganhar espaço no mercado comum - trata-se de mera aplicação das condições afetas à sua realidade econômica, inegável que haverá casos de flagrante abuso no que tange ao destacamento de trabalhadores, porém, é frágil e irreal o argumento de que tais delinquências empresariais derivam diretamente de ação dos governos locais.

Da mesma forma, é fato que a livre mobilidade da mão de obra na UE está a criar um ambiente de mercado de trabalho mais competitivo e que a remoção de barreiras à livre circulação de trabalhadores e serviços acirram a concorrência salarial. Evidente ainda a existência de abusos em relação ao destacamento de funcionários, todavia, é preciso perceber que tais questões são efeitos colaterais do próprio projeto europeu que não têm sido suficientemente bem-sucedido em harmonizar os diferentes contextos legais, sociais e organizacionais, criando um ambiente altamente fecundo para que as grandes corporações avancem com o processo de marquetização do trabalho, de precificação do labor e do bemestar das pessoas (conforme se verá no item 2.5).

Por fim, em que pese se reconhecer uma legítima preocupação com a observância e com o reforço nos padrões laborais e sociais na Europa, também é preciso ponderar a existência de um mau prognóstico sobre os rumos dos projeto de integração europeu que, ao menos na atual fase - de ajustamento em razão da recente abertura ao Leste e da profunda crise em 2008 -, a tendência não seja para uma "harmonização ascendente", tão menos a "corrida para o fundo", mas, sim, uma "convergência à média", na qual Estados de alto padrão tendam a limitar suas prestações sociais e flexibilizar normas laborais, ao passo que seus pares mais atrasados, passado o momento de crise, venham a aumentar seus padrões sociolaborais $^{264}$.

\footnotetext{
${ }^{264}$ Bunescu, 2011.
} 
$\mathrm{Na}$ tentativa de percepção da realidade do atual cenário europeu, há que se considerar ainda os fatores exógenos que têm alterado o ritmo do capitalismo, aumentando o nível de interdependência dos países, ao mesmo tempo em que confere um nível de mobilidade internacional do capital com a qual não se podia contar quando da elaboração da estratégia de integração da Europa. Esses fatores levam tanto a Alemanha, como a Romênia, por exemplo, a, igualmente, adotarem medidas de flexibilização a fim de aumentar seus níveis de competitividade, contudo, em que pesem tais ajustes serem impopulares em qualquer democracia do mundo, eles parecem suscitar maiores protestos e instabilidade política em países de alto padrão, o que leva muitos dos formuladores de políticas, no intuito de preservar a legitimidade do governo em exercício, a aderirem à retórica da necessidade ante a uma suposta concorrência desleal por parte de outros EM, de quem não se pode exigir um curso de trabalho superior ao respectivo nível de produção de riqueza ${ }^{265}$.

Isto posto, é patente a existência na UE de uma retórica proselitista, motivada por pressão popular diante da fatal vulnerabilidade de alguns setores da economia interna de países hegemônicos e cuja origem é multifatorial e muito mais complexa do que o maniqueísmo Norte-Sul ou Leste-Oeste faz crer.

\subsection{Sobre discursos polarizadores a partir de uma ideia de dumping social}

Em 07 de agosto de 2017, a agência de notícias Routers publicou em seu sítio na internet que o presidente da França, Emmanuel Macron, fez campanha na Europa Oriental para acabar com o "dumping social”, prática pela qual as empresas empregam mão de obra mais barata dos países mais pobres do Leste europeu, ameaçando os empregos dos trabalhadores franceses ${ }^{266}$. Em seguida, a mídia aponta a política de Macron como populista,

\footnotetext{
${ }^{265}$ Bunescu, 2011.

${ }^{266}$ Vey, J. B.; Kar-Grupat, S. \& Balmforth, R. (2017). France's Macron, on Eastern Europe trip, to raise issue of cheap labor. Reuters. [on-line]. Disponível em: $<$ https://www.reuters.com/article/us-france-easteuropemacron-idUSKBN1AN1G9>. Acesso em: 21 nov. 2018.
} 
protecionista e segregadora ${ }^{267}{ }^{268}$ e a primeira ministra polonesa, Beata Syzdlo, o destacou como arrogante e inexperiente ${ }^{269}$.

O discurso do dumping social não é novidade dentre os presidentes franceses: em 2011, Nicolas Sarkozy defende a necessidade de criar uma zona do euro separada dos demais países que não são do euro, justificando o pretenso separatismo no seu descontentamento sobre "dumping social e fiscal" e "concorrência desleal" dentro da UE ${ }^{270}$.

No Discurso Sobre o Estado da União 2017, o presidente da comissão europeia, Jean-Claude Juncker, destaca a "fragmentação social e o dumping social na Europa" como os problemas pelos quais "os Estados-membros têm de chegar a acordo sobre o Pilar Europeu dos Direitos Sociais o mais rapidamente possível"271.

O discurso do dumping social também não é bandeira neófita no âmbito do movimento sindical na Europa - no presente momento, a Confederação Europeia dos Sindicatos mantém a campanha: Free movement, yes! Social dumping, no!, através da qual pretende divulgar que workers in Europe are suffering from social dumping ${ }^{272}$.

Bernaciak chama a atenção para o fato de o termo dumping social estar presente nos discursos públicos desde os primeiros movimentos de liberalização comercial e integração econômica, tanto a nível político, como societal ${ }^{273}$ e que, apesar de seu amplo uso e de influenciar as estratégias dos atores às políticas de governo, não existe uma definição precisa para o termo, sendo frequentemente tomado por equivalente a "vantagens de custo

\footnotetext{
${ }^{267}$ Culbertson, A. (2017). Europe On The Edge: Macron to spark EU rupture as he cracks down on cheap eastern workers. Express. [on-line]. Disponível em: $<$ https://www.express.co.uk/news/world/838272/Emmanuel-Macron-EU-eastern-European-workers-labourFrench-labour-laws-Poland-Hungary>. Acesso em: 22 nov. 2018.

${ }^{268}$ Lough, R. \& Kelly, L. (2017). Emmanuel Macron wants to re-shape Europe. Business Insider. [on-line]. Disponível em: $<$ https://www.businessinsider.com/r-frances-macron-seeking-to-re-shape-europe-heads-east2017-8>. Acesso em: 22 nov. 2018.

${ }^{269}$ Culbertson, op. cit.

${ }^{270}$ The Economist. (2011). Two-speed Europe, or two Europes? [on-line]. Disponível em:

$<$ https://www.economist.com/charlemagne/2011/11/10/two-speed-europe-or-two-europes $>$. Acesso em: 22 nov. 2018.

${ }^{271}$ Comissão Europeia. (2017). O Estado da União. Disponível em:

$<$ https://ec.europa.eu/commission/sites/beta-political/files/state-union-2017-brochure pt.pdf $>$. Acesso em: 22 nov. 2018.

${ }^{272}$ European Trade Union Confederation. Free movement yes! Social dumping no! Disponível em: $<$ https://www.etuc.org/sites/default/files/publication/files/flyer_social_dumping_en_06.pdf $>$. Acesso em: 22 nov. 2018.

${ }^{273}$ Bernaciak, 2012, p. 12.
} 
injusta" advinda da "mera existência de salários mais baixos e condições de trabalho inferiores em países mais pobres ou menos desenvolvidos" 274 .

Fato é que expressões como "os canalizadores polacos" e "turismo de bem-estar" se fazem bastante presentes nos discursos de políticos populistas na busca por alimentar e explorar as preocupações dos cidadãos e acabam por construir uma leitura mistificada da realidade que, por conseguinte, vem a eclipsar todo um complexo processo de redefinição dos padrões sociais a partir de inúmeras clivagens presentes nos arranjos institucionais europeus que, por sua vez, de fato, deveriam ser objetos dos debates sobre as condições sociolaborais na Europa ${ }^{275}$.

Entretanto, nesse contexto, o objeto é o discurso, a retórica, que carreia o termo dumping social que, por si só, é bastante relevante e tem o poder de entusiasmar a opinião pública e, por conseguinte, de influenciar nos processos legislativos - neste sentido, vale analisar o texto de Arnholtz \& Eldring sobre as diferentes percepções a respeito de social dumping em países similares, no caso, Noruega e Dinamarca, a partir da adoção da retórica do dumping social pelo respectivos governos ${ }^{276}$.

Segundo os autores, tanto a Noruega, como a Dinamarca estabeleceram esquemas de transição em relação à migração individual de novos Estados-membros da EU, ao passo que tais regimes foram apoiados pelos sindicatos de ambos as países, que tinham slogans muito semelhantes em relação aos novos cidadãos da UE: "Todos são bem-vindos, mas em igualdade de condições" 277 .

Contudo, na Dinamarca ${ }^{278}$, o termo "dumping social" tem sido muito menos utilizado do que na Noruega ${ }^{279}$. Este fato se deu em decorrência de o novo fluxo de migrantes e os problemas potenciais que poderiam causar receberem bastante atenção na Dinamarca desde o início, mas estes problemas não foram incluídos sob o título de 'dumping social' como estavam na Noruega.

\footnotetext{
${ }^{274}$ Tradução nossa. "The mere existence of lower wages and inferior working conditions in poorer or less developed countries was regarded as an ('unfair') cost advantage, or the expression of a 'social dumping' intention" (Bernaciak, 2012, p. 16).

${ }^{275}$ Arnholtz, J. \& Eldring, L. Varying perceptions of social dumping in similar countries. In: Bernaciak, M. (2015). Market Expansion and Social Dumping in Europe. London: Routledge.

${ }^{276}$ Ibid.

${ }^{277}$ Tradução nossa. "Everyone is welcome, but on equal terms" (Ibid., p. 86).

${ }^{278} \mathrm{O}$ termo "dumping social" foi mencionado apenas 28 vezes em fontes centrais de notícias em 2003 , o termo ocorreu 253 vezes em 2004 e 446 vezes em 2006 (Ibid.).

${ }^{279}$ Uma simples análise de mídia do tipo já descrita acima mostra que o "dumping social" foi mencionado apenas 16 vezes em fontes de notícias centrais em 2003 e 105 vezes em 2005, antes de cair novamente para 15 vezes em 2007 (Ibid.).
} 
Nessa perspectiva, na Dinamarca, até 2011, sindicatos e políticos não utilizavam o termo "dumping social" ou quaisquer termos que pudessem empacotar genericamente questões relacionadas à baixa remuneração, evasão fiscal, atividade ilegal, etc. Na Noruega acontecia exatamente o oposto - a expressão era empregada oficialmente desde $2006^{280}$ como uma manifestação de um fenômeno social mais geral relacionada ao novo fluxo de trabalhadores. Essa diferença entre as abordagens norueguesa e dinamarquesa mostra que a compreensão do que constitui os padrões sociais e, consequentemente, o dumping social pode variar mesmo entre países muito parecidos que enfrentam desafios igualmente semelhantes ${ }^{281}$.

Ademais, em que pese existir incerta concordância quanto à importância da utilização do termo pelo discurso público entre a presente dissertação e o supramencionado texto, é relevante extrair do estudo em destaque o fato de que os autores demonstraram que realmente importa muito se o termo "dumping social" é ou não adotado como slogan político, posto que, a partir das lutas políticas - tanto discursivas quanto regulatórias -, é que se determina se os mecanismos e processos de reformulação dos padrões sociais são entendidos como partes aceitáveis e naturais de um mercado de trabalho europeu integrado ou se são entendidos como uma expressão de tendências anormais e problemáticas, de modo que a delimitação ou não de "dumping social" faz parte de uma luta política que gira em torno da questão da distinção entre pressões competitivas cotidianas aceitáveis de uma economia de mercado e problemas sociais inaceitáveis e extraordinários engendrados por uma concorrência "injusta"282, razão pela qual essa retórica deve ser utilizada com responsabilidade.

$\mathrm{Na}$ visão de Benescu, toda essa retórica populista e demagoga, na prática, culmina no que ela chama de "alegação" de dumping social, ou seja, no equivalente a uma "acusação" no sentido de "uma afirmação de que alguém fez algo errado ou ilegal, sem que tenha sido

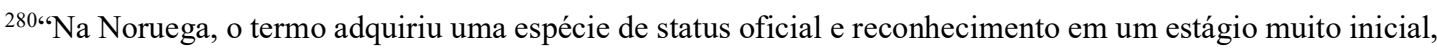
através do uso ativo do governo vermelho-verde e do lançamento e implementação de planos de ação para combater tais práticas. Segundo o governo da época, o dumping social poderia ser definido da seguinte forma: o governo considera que é um dumping social quando trabalhadores estrangeiros estão expostos a violações das regulamentações de saúde e segurança, incluindo regulamentos sobre tempo de trabalho e padrões de moradia, e quando são oferecidos salários e outros benefícios que são inaceitavelmente baixos comparados com os trabalhadores noruegueses ou se os salários não estão em conformidade com acordos coletivos legalmente estendidos, se tais estão em vigor" (Ministry of Finance, 2006 apud Arnholtz \& Eldring, 2015).

${ }^{281}$ Ibid.

${ }^{282}$ Ibid.
} 
provado" 283 que, por sua vez, recai sobre países como a Romênia que é comumente acusada de levar a cabo uma política consciente de baixos níveis salariais e de prestações sociais, sem se levar em consideração o fato de se estar a falar de um país em que, segundo a Eurostat, em 2009, os níveis de preços dos alimentos e bebidas não alcoólicas foi 34\% mais barata, ao mesmo tempo em que seu PIB per capita ficou 54\% abaixo da média da UE2 $7^{284}$.

Por fim, fato é que, à despeito de toda inconsistência no que tange à sua conceptualização e a adoção ou não do termo pelo discurso político, a constante presença das variadas noções de dumping social tem vindo a potenciar a polarização entre países desenvolvidos e países em desenvolvimento no âmbito do subsistema multilateral de comércio e também no subsistema regional de comércio, no qual se destaca a polemização das relações Norte-Sul e Leste-Oeste na União Europeia ${ }^{285}$.

\subsection{Dumping social ou Marketization?}

Valor e preço não se confundem; "valor de qualquer transação de mercado depende de sua posição e sua relação com todos os outros elementos de um determinado sistema de troca $[\ldots]$ a troca e os valores gerados por ela são contextualmente informados por uma variedade de fatores como história, ideologia e cultura" 286 , por seu turno, "o preço funciona como uma interpretação relativa do valor, e não é o valor em si”, contudo, serve como um meio de interpretação de valor que "desempenha a função de traduzir numerosas preferencias e valores concorrentes em linguagem comum"287, facilitando processos comparativos e, em vista disso, resultando no aumento da velocidade das transações de mercado.

Dito isto, em meio a todo o processo de expansão do comércio global e a consequente ampliação do domínio dos processos de concorrência e escolha, a valoração de uma transação de mercado que, a priori, levava em consideração elementos ou fatores de cunho histórico, ético, moral, cultural, etc., passa a adotar o preço como estratégia de

\footnotetext{
${ }^{283}$ Tradução nossa. "allegation” pinpoints particularly to a statement that someone has done something wrong or illegal, but that has not been proved" (Bunescu, 2011, p. 03).

${ }^{284}$ Ibid., p. 66.

${ }^{285}$ Vale mencionar ainda que a ideia de dumping social se fez presente nos conflitos de interesses entre EUA, Canadá e México no âmbito do NAFTA/USMCA.

${ }^{286}$ Malloy, R. P. (2017). Law, Market, and Marketization. University of Bologna Law Review (issue 2) 166. Disponível em: $<$ https://ssrn.com/abstract=3019495> . Acesso em: 28 jan. 2019.

${ }^{287}$ Ibid.
} 
eliminar subjetividade desse tipo de relação; em consequência, a concorrência baseada em preço se intensifica e se expande para áreas "que costumavam ser protegidas do mercado" 288 e resulta numa "crescente exposição de atores sociais ao mecanismo de mercado"289, paralelamente avançando silenciosamente por meio de uma gradual, porém consistente, reforma nas mais variadas instituições sociais, jurídicas, políticas, culturais, etc., a partir da linguagem e dos mecanismos típicos de mercado, de modo que, cada vez mais, valores como liberdade, igualdade, justiça e progresso são atrelados às noções de "custo e benefício", "eficiência", "competitividade" etc. ${ }^{290}$.

Essa é a ideia de marketization (marquetização ou mercantilização), ou seja, uma crescente e intensa concorrência essencialmente baseada em preços que estimula e é estimulada por uma tendente padronização dos processos produtivos e da prestação de serviços, simplificando e desenvolvendo o processo de concorrência ao nível de cada transação ${ }^{291}$.

Para Malloy, o processo de mercantilização é aquele em que várias instituições sociais, jurídicas, políticas e culturais se reformam tomando por referência mecanismos e valores de mercado e envolve uma reinterpretação das relações jurídicas e sociais em função das necessidades do comércio e, cada vez mais, dá prevalência a termos econômicos como a maximização da eficiência e da riqueza ao avaliar tais relações. Assim, num enfoque mais voltado para a mercantilização do Direito, o autor exemplifica sua concepção ao apontar situações em que juristas passam das discussões sobre "lei natural" e dos fundamentos morais da lei para conversas sobre análise de "custo e benefício" e a "Economia da Justiça" e, também, das instituições jurídicas que passam a atrelar a noção de "justiça" a termos como "eficiência", "oportunidade" e "resultados econômicos". Dessa forma, o processo de mercantilização altera o quadro de referência interpretativo legal de modo que a tomada de decisões passa a tomar por base cálculos de preços e outras considerações econômicas e a

\footnotetext{
${ }^{288}$ Greer, I. \& Doellgast, V. (2017). Marketization, inequality, and institutional change: Toward a new framework for comparative employment relations. Journal of Industrial Relations, 59(2), 192-208. Disponível em:

$<$ https://www.researchgate.net/profile/Ian_Greer3/publication/313486874_Marketization_inequality_and ins titutional change Toward a new framework for comparative employment relations/links/59fc66b40f7e9 b9968bd6e0c/Marketization-inequality-and-institutional-change-Toward-a-new-framework-for-comparativeemployment-relations.pdf>. Acesso em: 28 jan. 2019.

${ }^{289}$ Ibid.

${ }^{290}$ Ibid.

${ }^{291}$ Ibid.
} 
lei passa a servir ao propósito de comercialização, protegendo a propriedade, promovendo a produção e facilitando o consumo e o comércio ${ }^{292}$.

No entanto, é preciso alertar que mercantilização não se confunde com questões políticas ou ideológicas expressadas nas concepções amplas de neoliberalismo, livre cambismo, desregulamentação, etc.; seu enfoque é mais concreto, é o avanço da lógica mercantil sobre elementos da atividade social que não operavam via mecanismos baseada em preços, mais ainda, o avanço desse tipo de concorrência sobre "áreas" antes protegidas contra ela, implicando no desmantelamento de regulações e instituições orquestradas e implementadas pelos formuladores de políticas ${ }^{293}$. Bernaciak alerta ainda que esse tipo de expansão de mercado é "institucionalmente denso" no sentido de que, paralelamente à eliminação gradual de barreiras legais e institucionais ao mercado, envolve a criação de um novo conjunto de corpos voltadas para apoiar a lógica de trocas baseada no mercado ${ }^{294}$.

Assim, o processo de marketization leva à "desorganização"" das instituições nãomercantis de relações industriais e provisão de bem-estar ou à erosão de suas funções democráticas e redistributivas, além de fazer com que a atividade econômica se distancie das formas produtivas e não produtivas de busca pelo lucro, levando à expansão de novas formas de regulamentação pública e privada não democrática, tudo a contribuir com o aumento da desigualdade econômica e social ${ }^{295}$.

Esse fenômeno é facilitado e impulsionado pela padronização dos processos produtivos e de prestação de serviços ${ }^{296}$ em associação a um cenário de concorrência ampla e aberta favorecido pela globalização da economia, com maior evidência em projetos de

\footnotetext{
${ }^{292}$ Malloy, 2017.

${ }^{293}$ Bernaciak, M. (2014). Social Dumping and the EU Integration Process. In: SSRN Electronic Journal. 10.2139/ssrn. Disponível em:

$<$ https://www.researchgate.net/publication/314529559 Social_Dumping and the EU Integration_Process $>$. Acesso em: 24 jan. 2019.

${ }^{294}$ Ibid.

${ }^{295}$ Nunes, em contundente abordagem ao que entende der a conversão do "estado regulador" para um o chamado "estado garantidor", iniciado após a eclosão da crise de 2007/2008, processo em que, "para evitar as ineficiências geradas pela regulação, defende-se que o estado não faça regulação nenhuma, confiando a vida e o bem-estar das pessoas à eficiência do mercado". Abrindo-se espaço para que "À maneira do XVIII, o mercado (o mercado optimizado) fica senhor absoluto da economia, afastando dela o estado, ' matando' o estado económico e estado social. O mercado substitui o estado nas tarefas de 'governo' da economia e de redistribuição de rendimento. Em contrapartida, o estado 'paga' às (grandes) empresas prestadoras de 'serviços públicos' o desempenho daquelas tarefas, garantindo-lhes os lucros que o mercado não poderia garantir-lhes" (Nunes, A. J. A. (2012). A última máscara do estado capitalista. In: Estudos em Homenagem ao Prof. Doutor Aníbal Almeida. Colecção Stvdia Ivridica, 107, Ad Honorem - 7, Boletim da Faculdade de Direito de Coimbra, Coimbra: Coimbra Editora, 761-791, pp. 771-772).

${ }^{296}$ Processos que vão do fordismo até certificações como as do tipo "ISO" têm papel relevantíssimo na consolidação desse quadro.
} 
mercado único como o europeu, apontado por Gree e Doellgast como "a maior experiência em criação de mercado" que, por meio da livre circulação de bens, serviços, capital e trabalho, acaba por forçar mudanças em instituições encaradas como barreiras à abertura de mercados, de modo a desorganizar as relações laborais, criando ambiente de competição, bloqueando a colaboração entre nações e trabalhadores e erodindo o controle político ou burocrático $^{297}$.

Trata-se de um fenômeno de grande amplitude, cujas formas de atuação são diferenciadas por Gree e Doellgast em duas dimensões: a primeira, segundo os atores envolvidos, que podem ser organizações ou trabalhadores individuais; a segunda, em razão da escala de troca, diferenciadas em doméstica ou internacionais, implicando tipologia quádrupla conforme o seguinte quadro:

Tabela 1. Direcionadores de marquetização.

\begin{tabular}{|l|l|l|}
\hline & Organizações & Trabalhadores \\
\hline Internacional & $\begin{array}{l}\text { 1. Internacionalização do } \\
\text { comércio }\end{array}$ & $\begin{array}{l}\text { 3. Internacionalização da } \\
\text { migração laboral }\end{array}$ \\
\hline Doméstico & 2. Desintegração Vertical & $\begin{array}{l}\text { 4. Liberalização do mercado } \\
\text { de trabalho }\end{array}$ \\
\hline
\end{tabular}

Fonte: Greer \& Doellgast, 2017.

Posto isso, para os autores, a primeira chave da marquetização é a internacionalização do comércio via expansão do livre comércio que promove a concorrência entre os atores internacionais que atuam nas mais diversas áreas, desde a manufatura até serviços, tudo favorecido pela crescente mobilidade de capitais.

Desta tipologia de Gree e Doellgast, cabe aqui destacar o direcionador da desintegração vertical via introdução de mecanismos de mercado baseados em preço na organização interna dos processos produtivos; no setor privado eles citam a terceirização, o desmembramento das operações via joint ventures ou empresas derivadas; no setor público tais processos que, incialmente, atuaram via terceirização de áreas como limpeza, segurança

${ }^{297}$ Greer \& Doellgast, 2017. 
e manutenção, agora introduz o mecanismo de preço via privatização de serviços, como os postais, de telecomunicação, educação, saúde, etc. ${ }^{298}$.

Invertendo a sequência de trabalho dos autores cabe agora falar da flexibilização do mercado de trabalho, deixando a questão da mobilidade internacional de trabalhadores para o final, já que este é o tema mais comumente associado ao discurso do dumping social na Europa.

Isto posto, nas últimas três décadas, os governos foram aliciados a afrouxar as proteções estatutárias dos trabalhadores, introduzir contratos de trabalho temporários e reformar instrumentos de bem-estar social de várias maneiras para estimular o trabalho e desestimular o desemprego. Tal flexibilização tem se dado a partir das demandas do empregador, conferindo-lhe grande discricionariedade para contratar e demitir, bem como do afrouxamento das medidas de proteção e segurança no emprego. Ao contrário do que se encontra plasmado no discurso público, trata-se de um processo geral que não atinge com maior particularidade os países mais ou menos desenvolvidos. A pressão sobre os modelos de proteção ao trabalho é conjuntural e estrutural e as consequências se materializam tanto nos "mini-empregos alemães" ou contratos subsidiados franceses, como no Código de Trabalho da Romênia de 2011.

O processo de marketização não é invenção ou estratégia dos países menos desenvolvidos; o ambiente de competição é que lhes é imposto, pelo que essas nações são obrigadas a fazer uso das suas vantagens comparativas como meio de sobreviverem economicamente ao processo.

$\mathrm{O}$ último drive de marketization abordado é a migração internacional de trabalhadores provocada pela abertura do mercado de trabalho, cuja consequência é a intensificação da concorrência entre trabalhadores com especial destaque para União

\footnotetext{
${ }^{298}$ Embora não esteja a abordar especificamente esse processo sob a insígnia Marketization, Avelãs Nunes trata de sintetizar essa mesma percepção da realidade ao tecer suas considerações ao que chama de "a eficiência do mercado, a 'regulação' levada a cabo pelo próprio mercado são a melhor garantia do bem-estar das pessoas, pelo que será preferível que os serviços de utilidade pública sejam produzidos e colocados à disposição dos clientes por empresas privadas. [...] Levando esse raciocínio até o fim, um pequeno passo basta para se isentar o estado garantidor do dever de organizar e manter um serviço público geral e universal de educação (nomeadamente no que toca ao ensino obrigatório e gratuito) que a todos liberdade de aprender e ensinar, sem distinção de credos e ideologias. O mesmo poderá admitir-se quanto ao serviço nacional de saúde, aos serviços de segurança social (as seguradoras privadas estão desejosas de os prestar), aos serviços de água e de saneamento básico, aos serviços prisionais, até aos serviços de segurança (não há por aí importantes multinacionais que já prestam estes serviços, incluindo serviços militares, em palcos de guerra?) (Nunes, 2012, pp. 773-774).
} 
Europeia, em qual o processo de integração se destaca como uma forte promoção da liberdade de circulação do trabalho, alinhado com a liberdade de estabelecimento e com a mobilidade transnacional de serviços.

Em arremate, Malloy explica que o processo de mercantilização pode ser positivo, pois "expande as oportunidades de comércio", contudo, pode também ter implicações negativas na vinculação de "uma variedade de valores culturais e éticos a um sistema em que o preço não se limita apenas a uma interpretação de valor, mas é interpretado como valor propriamente dito", implicando numa "redução racional de sentimentos e emoções em um cálculo de custo e benefício; um cálculo no qual todos os valores humanos são expressos em termos de riqueza, segundo o qual a tudo é dado um preço, e a maximização da riqueza tornase o valor mais alto" 299 .

\subsubsection{O Whipsawing como Marketization.}

Um claro exemplo de marketização é o whipsawing, sendo este a introdução, por grandes corporações, de mecanismos de concorrência baseada em preços para extração de concessões de mão de obra. Trata-se de mecanismo sofisticado por meio do qual grandes empresas, em geral multinacionais, majoritariamente baseadas em países ricos, desenvolvem opções rápidas e baratas para realocação de produção, e se utiliza dessas opções de saída 300 como meio de "chantagem corporativa" 301 ou "encenação"302 para viabilizar transações entre a administração das empresas, força de trabalho e governos locais, visando concessões como reduções salariais, alterações nas jornadas laborais, concessão de benefícios físcais, alterações legislativas, etc., tudo sob ameaças como as de realocação da produção.

Trata-se de um fenômeno fortemente percebido na Europa onde um primeiro grande exemplo é o da competição por investimentos entre as plantas de montagem de automóveis de uma mesma corporação. Dessa maneira, a empresa promove o confronto entre as

\footnotetext{
${ }^{299}$ Tradução nossa. "Through the process of marketization law facilitates trades and exchanges in ways that validate unequal distributions of resources and that protect the owners of many assets from the desires of those who have fewer assets. At the same time, law creates a network infrastructure capable of peacefully organizing human activity across place, space, and time. This network infrastructure facilitates opportunities for all people to improve their well-being. In so doing, law provides a foundation upon which a market society may rest, and where the language of the market becomes ubiquitous in talking about and describing activities and relationships that had not previously been thought of in market terms" (Malloy, 2017, p. 182).

${ }^{300}$ Bernaciak, 2012, pp. 10-12.

${ }^{301}$ Ibid.

${ }^{302}$ Greer \& Hauptmeier, 2014.
} 
representações de trabalhadores dos locais aonde mantêm, ou pretende instalar, suas plantas produtivas, de modo que os futuros investimentos ficam condicionados a economias de custos de produção, são os chamados "concursos de beleza"303.

A indústria automotiva é o grande exemplo da marquetização via whipsawing pelo fato de que fez coincidir a renovação dos modelos de automóveis com os ciclos de investimentos que, junto aos processos produtivos altamente padronizados, lhe confere grande capacidade de realocação de produção.

Consoante Geer e Hauptmeier, a prática de whipsawing na indústria automotiva se inicia nos EUA nos anos de 1980 e se difundiu nas décadas de 1990 e 2000 dentre empresas europeias, incluindo a montadora italiana Fiat e as alemãs Volkswagen e Daimler Benz. Todo o desenvolvimento foi facilitado pelo contexto de liberalização fomentado pelos processos de criação e ampliação do mercado único europeu que, por sua vez, facilitou às empresas a integração de redes de produção e a mudança da produção através das fronteiras. Não obstante, os próprios autores alertam que o whipsawing não ocorreu apenas como resultado da competição entre locais de altos e baixos salários, embora isso tenha acontecido - o Sul da Europa, por exemplo, foi grandemente prejudicado; além disso, são muitos os casos de whipsawing via competições entre plantas localizadas num mesmo país, com destaque para a Alemanha ${ }^{304}$.

Como exemplo, em 2002, a Volkswagen exigiu aos sindicatos espanhóis um acordo visando mais flexibilidade no horário de trabalho; a proposta foi negada em sede de negociações com os trabalhadores locais e a VW cumpriu suas ameaças e transferiu $10 \%$ de sua produção para a fábrica de Bratislava, na Eslováquia, em questão de dias. A decisão de alocação só foi revertida quando os sindicatos cederam à pressão e concordaram com a flexibilidade de longo prazo desejada pelo grupo alemão ${ }^{305}$. De forma semelhante, a Daimler, em 2004, ameaçou transferir a produção de Stuttgart para Bremen para viabilizar um acordo permitindo a redução do pagamento de trabalhadores em serviços auxiliares como catering, limpeza, logística e segurança ${ }^{306}$.

\footnotetext{
${ }^{303}$ Tradução nossa. No original: "beauty contests", mais em: TRAPPMANN, Vera. Social dumping with no divide: evidence from multinational companies in Europe. IN: BERNACIAK, Magdalena.: Market Expansion and Social Dumping in Europe. New York: Routledge, 2015.

${ }^{304}$ Greer, I. \& Hauptmeier, M. Marketization and social dumping: Management whipsawing in Europe's auto industry. In: Bernaciak, M. (2015). Market Expansion and Social Dumping in Europe. London: Routledge. ${ }^{305}$ Ibid.

${ }^{306}$ Greer \& Hauptmeier, 2015.
} 
Neste ponto insta aclarar que o whipsawing não é exclusividade da indústria automotiva, mas, ao contrário, é um fenômeno que está em expansão e já chega a setores tradicionalmente caracterizados por altos níveis de sindicalização e proteção social, como o setor siderúrgico, e também ao seguimento da prestação de serviços altamente especializados, como o setor de tecnologia de informação (TI) - neste sentido é o estudo de Trappmann, que debruça sobre siderúrgicas multinacionais originárias de países anglosaxões e multinacionais de $\mathrm{TI}^{307}$.

A autora aponta como vias de resolução dos problemas a colaboração entre os atores prejudicados, a começar pelo diálogo transnacional entre os sindicatos, com sequência numa indispensável colaboração entre Estados via política e regulamentação supranacionais ${ }^{308}$.

Já Gree \& Hauptmeier alertam ainda para o fato de que existem diferenças entre a "versão grosseira do argumento do dumping social"309 (na presente dissertação abordado como 'discurso do dumping social') e a realidade do setor automotivo europeu. De pronto, no que tange aos atores-chave que impulsionam o fenômeno da whipsawing, os autores destacam que "governos nacionais em países pobres raramente desempenham um papel central" 310 , na verdade, "o gerenciamento central em multinacionais e, em menor medida, em representantes de trabalhadores e gestores locais em nível de firma e fábrica, é que impulsionam o fenômeno"311. Tal fato não quer dizer que os Estados sejam atores neutros nessa dinâmica, porém, eles tendem a fazer isso de maneira não intencional. Logo, a competição não se dá apenas entre países de altos e baixos salários - pode, sim, ser influenciada por reduções nos custos de mão de obra provocadas por concessões, mas também se dá, por exemplo, em razão da proximidade de mercados e da produtividade do trabalho. Além disso, os estudiosos alertam para o fato de que "a divisão de salários altos/baixos salários está em fluxo" e chamam atenção para casos, como o da Espanha, "um país com baixos salários se torna um país de altos salários; e, em outros momentos, como no

\footnotetext{
${ }^{307}$ Trappmann, V. Social dumping with no divide: evidence from multinational companies in Europe. In: Bernaciak, M. (2015). Market Expansion and Social Dumping in Europe. London: Routledge.

${ }^{308}$ Ibid.

${ }^{309}$ Tradução nossa. "Our analysis highlights differences between the crude version of the social dumping argument and the reality of the European automotive sector" (Greer \& Hauptmeier, 2015, p. 135).

${ }^{310}$ Tradução nossa. "First, the key actors driving the phenomenon of whipsawing are central management in multinationals and, to a lesser extent, firm-and plant-level worker representatives and local managers, and not national government in poor countries. The latter only rarely play a central role in whipsawing" (Ibid.).

${ }^{311}$ Tradução nossa. "States do matter, but it is more often the institutions - the sedimented results of past legislation - that shape these dynamics. They tend to do so in unintended ways; for example, when works councils use their right to democratic participation in the workplace to outcompete their counterparts elsewhere" (Ibid., pp. 135-136).
} 
caso da Polônia e de seus vizinhos do Leste, um país de baixos salários encontra-se em concorrência com países com salários ainda mais baixos"312.

\subsubsection{Marketization e a liberalização do mercado de trabalho na União Europeia}

Conforme já exposto, a marquetização, enquanto fenômeno associado à abertura do mercado, é particularmente percebida na Europa. Esses beauty contests ${ }^{313}$ são viabilizados pelo alto grau de padronização da produção, são impostos também aos governos locais de quem é exigido desde melhorias na infraestrutura até a flexibilização da legislação laboral, incluindo aí restrições à atividade sindical ${ }^{314}$.

\footnotetext{
${ }^{312}$ Tradução nossa. "Sometimes, as in the case of Spain, a low-wage country becomes a high-wage country; and at other times, as in the case of Poland and its neighbours to the east, a low-wage country finds itself in competition with even lower wage countries" (Greer \& Hauptmeier, 2015, p. 136).

${ }^{313}$ Tradução nossa. No original: "beauty contests" (Trappmann, 2015).

${ }^{314}$ Bernaciak, 2012.

${ }^{314}$ Ibid.
} 


\section{DO DISCURSO DO DUMPING SOCIAL AO DUMPING SOCIAL?}

Por todo o exposto até aqui, já se pode concluir pela existência e relevância do discurso do dumping social que, inclusive, tem influência na produção de legislação. Entretanto, a questão que agora se impõe é: o que é, então, dumping social?

Algumas tentativas de definição recolhidas da literatura acadêmica e do discurso público tentam conferir ao termo concepções como: (1) "concorrência desleal devido à aplicação de diferentes salários e regras de proteção social a diferentes categorias de trabalhadores" 315 ; (2) a ideia de que "prestadores de serviços estrangeiros podem minar os prestadores de serviços locais porque seus padrões de trabalho são mais baixos"316, no contexto do destacamento de trabalhadores na Europa; (3) o equivalente "à realocação de atividades para obter alguma vantagem competitiva" 317 pela ótica da deslocalização da produção, segundo um documento de discussão de 1998 do Center for Economic Policy; (4) “a decisão de um negócio em um país desenvolvido de suprir seu mercado interno por meio de produção localizada em uma economia em desenvolvimento onde as normas trabalhistas não cumprem os requisitos mínimos adotados pelo país de origem, permitindo assim que a empresa desfrute custos de produção mais baixos"318, segundo a clássica oposição entre países desenvolvidos e países em desenvolvimento; (5) "pressão descendente sobre as condições sociais devido à competição de países com condições sociais mais baixas" ${ }^{319}$, para

\footnotetext{
${ }^{315}$ Tradução nossa. "On 14 August 2015, Marianne Thyssen, European Commissioner for Employment, Social Affairs, Skills and Labour Mobility, gave a written answer to a European Parliament question on definitions, in which she stated: 'There is no definition of the concept of 'social dumping' in EC law. The term is generally used to point to unfair competition due to the application of different wages and social protection rules to different categories of workers" (European Foundation for the Improvement of Living and Working Conditions. Eurofound. (2016). Social dumping. Disponível em:

$<$ https://www.eurofound.europa.eu/observatories/eurwork/industrial-relations-dictionary/social-dumping $>$.

Acesso em: 04 mai. 2019).

${ }^{316}$ Tradução nossa. "In the context of the 'posting of workers' discussion, the European Commission escribed the practice as a situation "where foreign service providers can undercut local service providers because their labour standards are lower'." (Ibid.).

${ }^{317}$ Tradução nossa. "The decision of a business in a developed country to 'supply its domestic market through production located in a developing economy where labour standards do not comply with the minimum requirements adopted by the home country, therefore allowing the firm to enjoy lower production costs'." (Ibid.).

${ }^{318}$ Tradução nossa. "André Sapir (2015) uses the definition of social dumping as 'downward pressure on social conditions due to competition from countries with lower social conditions.". (Ibid.).

${ }^{319}$ Tradução nossa. "Where foreign service providers can undercut local service providers because their labour standards are lower'." (Ibid.).
} 
André Sapir ${ }^{320}$; (6) ou simplesmente "respeitar ou não respeitar a lei"321 no contexto de lealdade concorrencial segundo Vaughan Whitehead.

Fato é que, após o falhaço da proposta da Cláusula Social no âmbito da OMC, a busca por uma definição do dumping social se concentrou no seio da União Europeia. Dessa forma, o conceito oficial na Europa em 2012 correspondia ao respectivo verbete no Industrial Relations Dictionary da Eurofound como: "practice involving the export of goods from a country with weak or poorly enforced labor standards, where the exporter costs are artificially lower than its competitors in countries with higher standards, hence representing an unfair advantage in international trade" ${ }^{322}$.

Em texto de 2012, Bernaciak, mediante escorreita revisão da retórica pública e da literatura acadêmica, aponta arbitrariedades e erros comuns que levam a um entendimento simplista e abuso retórico na utilização do termo dumping social ${ }^{323}$ : (1) equivalência entre salários comparativamente mais baixos e padrões de emprego inferiores ao dumping social ${ }^{324}$; (2) arbitrária escolha dos padrões sociais de países desenvolvidos como referência e meta para standards sociais internacionais ${ }^{325}$; (3) foco em países menos desenvolvidos, de modo a ignorar o fato de que as políticas de dumping também são perseguidas por atores econômicos em ambientes de alto padrão ${ }^{326}$; (4) falhas na identificação dos mecanismos por trás do comportamento de dumping social, limitando-se, pois, a identificar o fenômeno por meio do apontamento das consequências ${ }^{327}$; (5) automaticidade na identificação do aumento de investimento direto estrangeiro nos países com salários considerados baixos,

\footnotetext{
${ }^{320}$ Sapir, A. (2015). Single market and social protection: friends or foes? Université Libre de Bruxelles. Presentation prepared for an Informal Meeting of Labor Ministers (revised). Hosted by Sweden's Minister for Employment. Stockholm, 11 September 2015. Disponível em:

$<$ http://bruegel.org/wp-content/uploads/2016/03/Sapir-2015-Stockholm.pdf $>$. Acesso em: 26 nov. 2016.

${ }^{321}$ Tradução nossa. "Vaughan-Whitehead (2003) pointed out that a distinction could be drawn between a narrow definition of social dumping, limited to respecting or failing to respect the law, and a more general definition based in the notion of 'unfair competition'." (European Parliament, 2017).

322“Uma prática que envolve a exportação de bens de um país com padrões trabalhistas fracos ou mal aplicados, em que os custos do exportador são artificialmente mais baixos do que seus concorrentes em países com padrões mais elevados, representando uma vantagem injusta no comércio internacional" (tradução nossa. Bernaciak, 2012, p. 19).

${ }^{323}$ Bernaciak, op. cit.

324"This conceptualisation suffers from two flaws, however. First, it follows the popular understanding of lower wages and inferior employment standards as equivalent to social dumping and 'unfair' competition" (Ibid., p. 19).

325“'Second, it is unclear on what basis one can label the price of developing country exports 'artificially" low" (Ibid.).

326"The authors seem to implicitly refer to developed/ high-wage country standards, but the decision to adopt them as benchmark is an arbitrary, normative choice" (Ibid., p. 19).

327 "They fail to identify the mechanism behind the dumping behavior" (Ibid., p. 20).
} 
comparativamente aos países desenvolvidos, como impulsionados exclusivamente por custos de mão de obra, ignorando, por exemplo, critérios afetos à eficiência e ao mercado ${ }^{328}$; (6) uso de Banckmarks arbitrários para avaliar quanto uma empresa deve pagar a seus empregados ou se os salários do país hospedeiro estão "bem abaixo" de determinados países $^{329}$; (7) definições incompletas e difíceis de se operacionalizar ${ }^{330}$; (8) inferências casuais de difícil comprovação empírica ${ }^{331}$; e (9) utilização de "inferências causais" de difícil comprovação empírica para apontar um elo entre uma prática de dumping social e a estagnação ou deterioração do ambiente social ${ }^{332}$;

Sobre a definição oficial de dumping social na União Europeia, a mesma estudiosa contesta o conceito contido no supramencionado verbete, apontando nele ao menos duas grandes falhas: a equivocada equivalência de baixos salários e padrões laborais supostamente "frágeis" ou "inferiores" à "concorrência desleal"; e a concepção demasiadamente frágil e subjetiva carreada pela expressão "artificially lower", capaz de induzir o entendimento arbitrário de que os padrões de referência são os praticados nos países de alto padrão. Ato contínuo, a autora conceitua o dumping social como: "The strategy geared towards the lowering of social standards for the sake of enhanced competitiveness. It is prompted by companies but indirectly involves their employees and/or home and host country governments, and has negative implications in the social sphere" ${ }^{333}$.

Importante perceber que a abordagem de Bernaciak evita as armadilhas das concepções convencionais e identifica o objetivo do dumping social como sendo o "aumento da competitividade", os efeitos prejudiciais que a prática implica com o "rebaixamento dos padrões sociais" e os atores envolvidos sendo as “empresas", com possível colaboração dos "trabalhadores e governos [...]"334.

\footnotetext{
328“Fails to distinguish between efficiency and marketseeking investments, and does not account for the practice of transferring most labour-intensive operations to worker-rich countries and concentrating higher value-added activities at home, which might enhance the company's competitiveness and, in consequence, benefit both home and host country units" (Bernaciak, 2012, p. 21).

329“"arbitrary benchmarks: it is impossible to assess how much the company should pay its employees, or at which point exactly host country wages are 'well below' those in the home country" (Ibid.).

330"their definitions are often incomplete or difficult to operationalize" (Ibid.).

331 "authors are arbitrary in assigning high-wage countries' social standards as universal criteria" (Ibid., p. 22).

332" Authors often make causal inferences that are hard to prove empirically; the link between the alleged social dumping practice and the stagnation of social standards in the host country is a case in point" (Ibid., p. 22).

${ }^{333}$ Ibid., pp. 19-20.

${ }^{334}$ Nessa mesma linha, opina Linos, [s.n.], p. 04.
} 
No entanto, em obra lançada em 2015, Bernaciak aponta o dumping social como sendo uma "subcategoria específica de marquetização" e passa a defini-lo como: "the practice, undertaken by self-interested market participants, of undermining or evading existing social regulations with the aim of gaining a short-term advantage over competitors" 335 .

Portanto, identifica o objetivo do dumping social como sendo "obter vantagem de curto prazo sobre os concorrentes". Os efeitos prejudiciais que a prática implica com o "minar ou burlar das regulamentações sociais existentes", mas chama atenção o fato de que a mesma tornou mais difusa a identificação dos atores envolvidos quando os identifica como sendo "participantes do mercado".

Em 19 de maio de 2016 o texto do mesmo verbete do Industrial Relations Dictionary é revisado e passa a se abster de apresentar uma definição para o termo alegando que:

Despite an increase in usage of the expression, there is still no clear, universally accepted definition of 'social dumping'. Social dumping is a hotly debated issue in European circles, the term itself having negative connotations, hinting at the exploitation of workers ${ }^{336}$.

Já em 21 março de 2017, o Parlamento Europeu divulga um briefing intitulado "Understanding social dumping in the European Union"337, em que atesta a ausência de definição precisa para o termo por meio de sentenças como: "social dumping has neither a generally accepted definition, nor easily definable limits" 338 e "Despite increasing usage of the expression 'social dumping', there is no clear, universally accepted definition of the term"339.

\footnotetext{
${ }^{335}$ Bernaciak, 2015, p. 10.

${ }^{336}$ Tradução nossa: "ainda não existe uma acepção clara e universalmente aceita para o mesmo, mas que é uma questão muito debatida nos círculos europeus, tendo o próprio termo conotações negativas, insinuando a exploração dos trabalhadores" (Eurofound, 2016).

${ }^{337}$ European Parliament. (2017). Understanding social dumping in the European Union. Disponível em: $<$ http://www.europarl.europa.eu/RegData/etudes/BRIE/2017/599353/EPRS BRI(2017)599353 EN.pdf>.

Acesso em: 04 mai. 2019.

${ }^{338}$ Ibid.

${ }^{339}$ Ibid.
} 
Em arremate, o que se tem por inconteste é o fato de a inexistência de acepção oficial, aliado à inconsistência na literatura acadêmica, para o termo confere ares quixotescos ${ }^{340}$ à alardeada luta à "fragmentação social e o dumping social na Europa"341.

Independentemente do supramencionado, a posição adotada pela presente dissertação é a de que toda e qualquer conceptualização de dumping social que não mantenha estreita relação com a delimitação oficial de dumping contida no ARRU é apropriação indevida do termo, pelo que vale aqui destacar o conceito carreado por Bunescu:

Social dumping is a practice involving the export of goods from a country with weak or poorly enforced labour standards, where the exporter's costs are artificially lower than its competitors in countries with higher standards, hence representing an unfair advantage in international trade. It results from differences in direct and indirect labour costs, which constitute a significant competitive advantage for enterprises in one $e^{342}$.

A autora também faz uma interessante ponderação ao argumentar que social dumping não deve ser entendido como sinônimo de welfare dumping ${ }^{343}$, de modo que este se daria na medida em que o estado reestrutura ou reduz as transferências e os esquemas de proteção social, implicando em mudanças do universalismo do seguro social para a seletividade, assim, para a determinação específica dos grupos-alvo para os quais o estado tem que realizar essas transferências, implicando, ao final, no repasse dessas obrigações do estado e do empregador para os trabalhadores e comunidades nas quais eles vivem.

No entanto, a própria Besnescu cita o trabalho de Gøsta Esping-Andersen e este, no seu livro The three worlds of welfare states capilaism, publicado em 1990, apresentou suas conclusões a respeito de um escorreito estudo sobre "o desenvolvimento do welfare state em

\footnotetext{
${ }^{340}$ Em sua clássica obra, Miguel de Cervantes não deixa margem para que se possa duvidar da dignidade e da elevação dos valores do engenhoso fidalgo, contudo, a busca desenfreada pelo idealismo, pela virtude plena, leva "el caballero de la triste figura" a se divorciar da realidade e enveredar-se numa engenhosa construção de fantasias, como se pode ver: “-jVálame Dios! -dijo Sancho-. ¿No le dije yo a vuestra merced que mirase bien lo que hacía, que no eran sino molinos de viento, y no lo podía ignorar sino sino quien llevase otros tales en la cabeza? -Calla, amigo Sancho -respondió don Quijote-, que las cosas de la guerra, más que otras, están sujetas a continua mudanza; cuanto más, que yo pienso, y es así verdad, que aquel sabio Frestón que me robó el aposento y los libros ha vuelto estos gigantes en molinos por quitarme la gloria de su vencimiento: tal es la enemistad que me tiene; mas, al cabo al cabo, han de poder poco sus malas artes contra la bondad de mi espada. -Dios lo haga como puede -respondió Sancho Panza" (Cervantes, M. Don Quijote I (Spanish Edition) (Kindle Locations 1018-1026). Kindle Edition).

${ }^{341}$ Para usar as palavras de Jean-Claude Juncker no "Discurso Sobre o Estado da União" de 2017 (Comissão Europeia, 2017).

${ }^{342}$ Bunescu, 2011

${ }^{343}$ Ibid., p. 23.
} 
países de capitalismo avançado ${ }^{344 ”}$. De acordo com o autor, “o welfare state não pode ser entendido apenas em termos de direitos e garantias"345, ao passo que "a mera presença de assistência ou seguro sociais não necessariamente emancipam substancialmente o indivíduo da dependência do mercado" 346 , podendo, inclusive, ser, em si mesmo, "um sistema de estratificação social" 347 , na medida em que "a tradição de ajuda aos pobres e a assistência social a pessoas comprovadamente necessitadas, fora planeada com o propósito de estratificação"348. A partir de constatações como essas, Esping-Andersen agrupa os estados sociais pioneiros em três tipos de regimes bastante distintos, não sem antes destacar o fato de que fatores como nível de industrialização, crescimento econômico ou poder político dos trabalhadores têm "muito pouco" poder de influenciar na consideração do tipo (ou "mundo") de welfare state a que pertence uma nação, já que é resultante de "interações notáveis" entre "forças causais" 349. Tais constatações, por si só, mostram extrema fragilidade da ideia de que os níveis de proteção social são susceptíveis de singela comparação acoplada na ideia de welfare dumping ou na de dumping social.

Das lições de Moreira, extrai-se que:

O argumento do "dumping social" está associado a uma percepção generalizada nos países desenvolvidos segundo a qual a inobservância ou déficit de direitos laborais em muitos países, especialmente nos países menos desenvolvidos, lhes confere vantagens ilegítimas no comércio internacional e na atração de investimento estrangeiro $^{350}$.

\footnotetext{
${ }^{344}$ Tradução nossa. "The welfare state cannot be understood just in terms of the rights it grants" (EspingAndersen, G. (1998). The three worlds of welfare states capilaism. New Jersey: Princenton Press, p. 21).

345"The welfare state is not just a mechanism that intervenes in, and possibly corrects, the structure of inequality; it is, in its own right, a system of stratification" (Ibid., p. 30).

${ }^{346 " T h e ~ m e r e ~ p r e s e n c e ~ o f ~ s o c i a l ~ a s s i s t a n c e ~ o r ~ i n s u r a n c e ~ m a y ~ n o t ~ n e c e s s a r i l y ~ b r i n g ~ a b o u t ~ s i g n i f i c a n t ~ d e-~}$ commodification if they do not substantially emancipate individuals from market dependence" (Ibid.).

347"The welfare state is not just a mechanism that intervenes in, and possibly corrects, the structure of inequality; it is, in its own right, a system of stratification" (Ibid.).

348"Comparatively and historically, we can easily identify alternative systems of stratification embedded in welfare states. The poor-relief tradition, and its contemporary means-tested social-assistance offshoot, was conspicuously designed for purposes of stratification. By punishing and stigmatizing recipients, it promotes social dualisms and has therefore been a chief target of labor-movement" (Ibid., pp. 32-33).

349"If welfare states cluster into three distinct regime-types, we face a substantially more complex task of identifying the causes of welfare-state differences. What is the explanatory power of industrialization, economic growth, capitalism, or working-class political power in accounting for regime-types? A first superficial answer would be: very little. The nations we study are all more or less similar with regard to all but the variable of working-class mobilization. And we find very powerful labor movements and parties in each of the three clusters" (Ibid., p. 38).

${ }^{350}$ Moreira, 2014, p. 38.
} 
Desse modo, dumping social seria um termo "vulgarmente" 351 utilizado para os casos "de deliberada redução dos níveis de proteção laborais (ou abstenção deliberada de os aplicar), para obtenção de vantagem competitiva"352, contudo, "não configuram uma hipótese de dumping em sentido próprio nem em sentido de substituição das exportações", ou seja, "não se trata de dumping, porque esta figura consiste na exportação a um preço inferior ao de mercado de origem, por decisão das empresas exportadoras, a fim de obter maior acesso aos mercados externos" 353 , uma vez que o dumping social seria decorrente "das condições proporcionadas pelo Estado ao desproteger os direitos laborais nessas áreas" ${ }^{354}$.

Não obstante, dado o nível de interdependência e os consequentes avanços nas cadeias de produção globais, os produtos e serviços são cada vez mais "made in world"355, de modo que qualquer abordagem dos problemas inerentes ao atual modelo global de produção e prestação de serviços não deveria se centrar somente no papel do estado, ignorando, por conseguinte, o protagonismo dos agentes econômicos que já não têm mais fronteiras para atuar e se utilizam dos mais variados aparatos para achacar trabalhadores e governantes $^{356}$, precificando direitos laborais, exigindo toda sorte de investimentos em infraestrutura ao mesmo tempo em que condicionam a criação ou manutenção de postos de trabalho à incentivos fiscais e flexibilização das leis trabalhistas.

À vista disso, as práticas apontadas pelo discurso do dumping social são mais facilmente imputáveis aos agentes econômicos, o que, de per si, inviabiliza o dumping social enquanto espécie derivada do gênero dumping (comercial), fato que, por sua vez, tem o condão de fundamentar um argumento de apropriação indevida do termo "dumping", retórica do comércio desleal baseado em exploração dos direitos sociais.

\footnotetext{
${ }^{351}$ Moreira, 2014, p. 38.

${ }^{352}$ Ibid.

${ }^{353}$ Ibid., p. 106.

${ }^{354}$ Ibid.

${ }^{355}$ Expressão também utilizada por Moreira, 2014.

${ }^{356}$ Quanto ao papel dos atores econômicos, mais notadamente as grandes empresas multinacionais, enquanto agentes ou sujeitos de práticas apontadas no discurso do dumping social, que se aproveitam das lacunas econômicas, sociais e jurídicas entre as nações para otimizarem seus lucros e satisfazerem seus acionistas, via práticas de marquetização como a já destacada whipsawing. Neste ponto, a prática não compactua com o discurso, posto que a maior parte dessas empresas e desses acionistas estão baseados nos países ricos, pelo que, de certo modo, é possível apontar os países receptores dos lucros, incluindo os paraísos fiscais, como responsáveis finais das práticas apontadas na retórica do dumping social. É uma questão de seguir o dinheiro (follow the money) e punir quem realmente lucra com a exploração abusiva dos trabalhadores ao invés de inviabilizar o desenvolvimento econômico das nações mais pobres.
} 
Outrossim, a partir de estudos como os de Bernaciak, Bunescu e outros autores com significativos estudos na temática, a presente investigação constatou que as mais variadas abordagens sobre o dumping social fatalmente acabam por ignorar um ou outro dos pontos aqui considerados fundamentais, nomeadamente: (1) a importância das cadeias globais de valor que, por sua vez, fazem com que os produtos ou serviços fornecidos por países em desenvolvimento com inputs na cadeia produtiva de um produto final a ser comercializado por países de alto padrão fiquem de fora do discursão; (2) práticas adotadas por empresas que deliberadamente violam ou burlam a legislação no campo social ou se aproveitem de lacunas entre as legislações dos diferentes países para obter vantagem econômica em termo de competitividade; (3) a verificação das circunstâncias em que se deram investimentos diretos estrangeiros, se o mesmo se deu exclusivamente em razão de baixos padrões sociais, além da comprovação de que ambiente social daquele país receptor fora ou está sob ameaça de ser deteriorado; (4) a identificação do impacto negativo sobre os padrões sociais no local dumped, devendo se estabelecer um nexo causal entre o dumping social e suas consequências, como aumento do desemprego e da taxa de falência, assim como a erosão dos sistemas de pagamento e da rede de proteção social; (5) os critérios que levam à delimitação de uma prática específica de dumping social, considerando a sua parcela de "culpa" em relação aos demais fatores de erosão das condições de emprego e saúde dos sistemas de segurança social.

De mais a mais, não restam dúvidas que existem neoprotecionismo, diferenças entre nações quanto ao nível de proteção social, marquetização, exploração de trabalhadores por grandes empresas, uma retórica pública fortemente disseminada da qual se extrai uma suposta prática desleal de comércio perpetrada por países pobres no intuito de roubar empregos dos países ricos, porém, existem ainda severas dúvidas sobre a existência de dumping social enquanto instituto jurídico ou econômico, especialmente considerando o artigo IV do GATT. 


\section{CONCLUSÃO}

Ante matérias de tamanha relevância e abrangência, é inevitável que aqui restem inúmeras vertentes inexploradas, no entanto, dentro dos limites propostos, mostrou-se, na presente dissertação, num primeiro momento, a evolução do comércio internacional, com destaque para organismos multilaterais, para, na sequência, se apontar as bases teóricas sobre as quais estudiosos como Jacob Viner identificaram, nomearam e justificaram o dumping como fenômeno jurídico-econômico, mas que, nos dias que correm, não encontra fácil harmonização com a pragmática liberal do multilateralismo e do comércio livre, de modo que, a aplicação do dumping, via medidas antidumping, só se justifica em casos extremos, pois tem o condão de causar consideráveis desequilíbrios na livre concorrência comercial entre nações. Ocorre que, a legislação internacional a regulamentar a aplicação de medidas antidumping se mostra demasiada opaca e lacunosa, dando grande margem de discricionariedade para que os países, via procedimentos unilaterais, possam ser arbitrários na sua aplicação, ignorando os valores e os objetivos da norma internacional, como consequência, têm-se que o dumping e os direitos antidumping são, na prática, instrumentos à disposição de políticas neoprotecionistas ou desenvolvimentistas que põem em rota de colisão os interesses comerciais dos países atualmente desenvolvidos com os dos países em desenvolvimento.

Em seguida, buscou-se apresentar e entender a teoria de Ruud Koopmans, segundo a qual discursos polarizadores carecem de legitimidade, mas ganham em ressonância e, por conseguinte, em visibilidade, para apontar o discurso (a retórica, a acusação, o argumento, etc.) do dumping social enquanto recurso ilegítimo utilizado no âmbito do sistema de comércio internacional, em especial no subsistema multilateral de comércio e no subsistema regional, para, por meio de "mensagens polarizadoras", ganhar ressonância e visibilidade. Demonstrou-se, enfim, que tal estratagema carece de legitimidade por apontar um falso trade off entre comércio livre e standards sociais. No ademais, destacou-se que tal retórica viabilizou proposições legislativas equivocadas, como a "cláusula social" no âmbito do subsistema multilateral de comércio e as mais recentes propostas de diretivas europeias em resposta à famigerada "fobia ao canalizador polonês" no caso da prestação de serviços transfronteiriços no domínio daquele subsistema regional de comércio. 
Buscou-se ainda, demonstrar serem tais proposições legislativas simplórias e inaptas a alcançar o âmago dos problemas postos na arena global, estes, resultado de uma longa e complexa trama que vem se aprofundando, pois está sempre em movimento, e que não comportam diagnósticos e soluções simples e, ao contrário do que faz crer o ambiente maniqueísta incitado pelo discurso do dumping social, fato é que tais adversidades, só podem ser colmatadas via convergência de esforços.

A proposta de "cláusulas sociais" no âmbito da $\mathrm{OMC}$, que se deu mediante discursos públicos dos líderes dos PAD a apontar o menor custo da mão de obra e o baixo nível de proteção social como vantagens comparativas injustas utilizadas propositalmente pelos PED com o desleal desígnio de fortalecer os agentes econômicos internos e deslocalizar indústrias e fornecedores de serviços referenciados nos países hegemônicos, obteve a forte reação dos representantes dos PED que, por sua vez, argumentaram serem os níveis salariais e de proteção social praticados em cada país consequência inevitável dos seu respectivo estágio de desenvolvimento econômico. Sem se pretender isento, e sem abdicar de críticas às posturas externadas no âmbito da discursão, o presente texto buscou demonstrar a tal retórica na qual se alicerçaram as propostas das "cláusulas sociais" no âmbito da OMC como, essencialmente, polarizadoras, por conseguinte, inábeis a se apresentar como soluções para os impasses da globalização, que, por natureza, são complexos e pedem colaboração e não confrontação.

Outro destaque do segundo tópico é a defesa da OIT como foro internacional ideal para tratar da implementação e preservação de standards sociais, não só por sua antiguidade enquanto organização internacional, mas, também, pelo seu pioneirismo, expertise, capacidade de inovação e, notadamente, pelo fato de se tratar da única organização internacional a contar com a presença de governos, empresários e trabalhadores. Por outro lado, demostrou-se ser, no mínimo, imprudente, transformar a OMC - uma instituição internacional com elevado número de Estados-membros que se comprometem com suas regras, que, por sua vez, são marcadas pela clareza, objetividade e pragmatismo e um sistema de resolução de conflitos o mais apolítico possível - em tutora de temas que não são, objetivamente, inerentes ao comércio internacional, de modo a trazer a subjetividade necessária à politização do sistema de resolução de conflitos da $\mathrm{OMC}$, transformando-o num foro social e político a tratar de padrões morais, via critérios subjetivos e potencialmente discricionários. 
No que tange às propostas de diretivas em resposta à "fobia ao canalizador polonês" no caso da prestação de serviços transfronteiriços no âmbito da União Europeia, partiu-se do seu contexto de integração/expansão, com o lançamento do Mercado Único e os alargamentos à sul e à leste para tentar desnudar o fato de que a política de integração da EU - mais tendenciosa aos processos de mercado do que à manutenção da regulação social permite, por exemplo, que empresas multinacionais, baseadas principalmente em países ricos, organizem sua produção de forma a explorar as clivagens entre os padrões sociais das nações europeias. Para tanto, o presente trabalho se propôs a trazer à lume a polêmica do "canalizador polonês", associado ao trabalho destacado no âmbito da prestação de serviços transfronteiriços no mercado comum, como um claro exemplo do papel nocivo que o discurso do dumping social pode desempenhar no âmbito do subsistema regional de comércio internacional. Desta forma, o texto apresentou conceitos como o de trabalho destacado, o histórico do mesmo no âmbito da União Europeia, as diretivas vigentes e propostas visando equacionar eventuais conflitos resultante da prática de envio temporário de funcionários para outro EM, mas, sobretudo, o fato de que o destacamento de trabalhadores tornou-se elemento central nos discursos do dumping social no âmbito da União Europeia, com ênfase nas retóricas populistas que, emanadas por políticos, sindicatos e agentes econômicos, pressionam as instituições europeias como Conselho e o Parlamento, acabando por minar a consecução do ideal de liberdade na prestação de serviços. Mais adiante, destacou-se a equilibrada atuação do Tribunal de Justiça da União Europeia, que, por sua vez, se mostra resiliente quanto às pressões advindas do discurso do dumping social.

Os arremates dessa segunda etapa ficam por conta da apresentação da ideia de marketization (marquetização ou mercantilização), como exemplo de abordagem mais racional, e não polarizadora, que pode ajudar a esclarecer os processos grosseiramente abordados pela retórica do dumping social.

No último capítulo, apesar de o presente texto não ter por objeto o dumping social em si, buscou-se demostrar sua inconsistência, sua incoerência e a inutilidade da sua respectiva delimitação ou conceptualização enquanto variante do dumping (comercial), tudo com o fito de reafirmar a importância e a autonomia do discurso, da retórica, da narrativa que carrega uma mensagem poderosa, polarizadora, segregadora, capaz de opor PAD e PED no multilateralismo, norte-sul, leste-oeste na União Europeia. 
Neste ponto, espera-se que reste indubitável que este estudo não se prestou a defender um ou outro modelo econômico, político e/ou social, mas que partiu-se da realidade posta, dos modelos adotados e, consequentemente, dos seus pressupostos, de modo que a crítica aqui se centrou na ausência de neutralidade que medidas baseadas no discurso do dumping social impõem à essa realidade, isto é, criticou-se fatos como o de os EUA, que patrocinaram a criação das instituições de Bretton Woods, ajudaram a promover o livre cambismo baseado na teoria de Smith, Ricardo, etc., virem a se utilizar de uma retórica que, ao cabo, vem a tentar obstaculizar os PED de fazer uso de suas vantagens comparativas; da mesma forma, os pioneiros do projeto europeu - que o alicerçaram a partir da lógica de mercado - depois de se apropriarem, via instituições europeias sediadas em Frankfurt, Bruxelas, etc., da maior parte dos elementos classicamente utilizados em estratégias de catching up, passem, por meio da retórica (ou da acusação) de dumping social, a dificultar o acesso de agentes econômicos do sul ou do leste ao mercado comum.

Outrossim, espera-se que o leitor tenha percebido que aqui não se pretendeu bloquear as legítimas demandas pela melhoria das condições sociolaborais, mas, ao contrário, o que se colocou é que tais mazelas existem e são gravíssimas, contudo, suas origens são estruturais, decorrentes do modelo neoliberal escolhido e posto em prática pelos países pioneiros no capitalismo, resultante da promoção do desmonte do Estado e das instituições de proteção sociais em nome de uma suposta "eficiência econômica" advinda da concorrência desmedida, precificando a tudo e todos. Porém, a fatura de tais "reações adversas" é imposta pelo discurso do dumping social aos governos e trabalhadores das nações mais pobres.

Por fim, não se pretendeu oferecer alternativas aos modelos adotados, mas tão somente alertar para o fato de que seus preceitos não são aplicados igualmente para todos, sendo o discurso do dumping social um instrumento utilizado para consecução de tal desiderato. É preciso destacar inclusive a esquizofrenia gerada pela somatória das narrativas hegemônicas que ao mesmo tempo em que prega o encolhimento do Estado - por exemplo, se exigindo rígida disciplina fiscal com cortes de gastos em todas as áreas, restando a ele a incumbência de não atrapalhar o bom funcionamento do mercado - o responsabiliza quando o mercado falha na proteção social e laboral, nomeadamente, acusando nações e seus governos de conduta desleal em razão da "baixa proteção social". 


\section{REFERÊNCIAS}

Abbott, K.; Keohane, R.; Moravcsik, A.; Slaughter, A. \& Snidal, D. (2000). The Concept of Legalization. International Organization. In: International Organization, v. 54, n. 3, pp. 401-419. Disponível em: $<$ https://www.cambridge.org/core/journals/internationalorganization/article/the-concept-oflegalization/EF6AA703676B5053168AC43C27BF45A4>. Acesso em: 28 jul. 2018.

Almeida, L. C. B. (2012). Introdução ao direito econômico: direito da economia, direito econômico, law and economics, análise econômica do direito, direito econômico internacional. 4. ed. São Paulo: Saraiva.

Amador, J. (2017). Portugal e o Comércio Internacional. Lisboa: Fundação Francisco Manuel dos Santos.

Arnholtz, J. \& Eldring, L. Varying perceptions of social dumping in similar countries. In: Bernaciak, M. (2015). Market Expansion and Social Dumping in Europe. London: Routledge.

Barboza, D. (2010). A Night at the Electronics Factory. New York Times. [on-line]. Disponível em:

$<$ https://www.nytimes.com/2010/06/20/weekinreview/20barboza.html?ref=foxconntechnol ogy $>$. Acesso em: 23 jul. 2018.

Barral, W. (2000). Dumping e comércio internacional: a regulamentação antidumping após a rodada do Uruguai. Rio de Janeiro: Forense.

Bastos, E. L. (2012). Estudo analítico do dumping na esfera internacional. Curitiba: Juruá, 2012.

BBC News. (2005). French say firm 'No' to EU treaty. [on-line]. Disponível em: $<$ http://news.bbc.co.uk/2/hi/europe/4592243.stm $>$. Acesso em 04 de fevereiro de 2019.

. (2005). 'Polish plumber' beckons French. [on-line]. Disponível em:

<http://news.bbc.co.uk/2/hi/europe/4115164.stm>. Acesso em: 04 fev. 2019.

Bensoussan, F. G. \& Gouvêa, M. F. (2016). Manual de Direito Econômico. 2. ed. Salvador: JusPodivm, pp. 643-644. 
Bernaciak, M. (2012). Social Dumping: Political Catchphrase or Threat to Labour Standards? In: SSRN Electronic Journal, 10.2139/ssrn.2208393, p. 09. Disponível em: $<$ https://www.researchgate.net/publication/256045521_Social_Dumping_Political_Catchp hrase_or_Threat_to_Labour_Standards $>$. Acesso em: 25 jul. 2018.

. (2014). Social Dumping and the EU Integration Process. In: SSRN Electronic Journal. 10.2139/ssrn. Disponível em:

$<$ https://www.researchgate.net/publication/314529559 Social_Dumping and the EU Inte gration_Process $>$. Acesso em: 24 jan. 2019.

Bliacheriene, A. C. (2007). Defesa Comercial. São Paulo: Quartier Latin.

Bonefeld, V. (2012). Freedom, Crisis and the Strong State: On German Ordoliberalism. British International Studies Association. [on-line]. Disponível em: $<$ https: $/ /$ www.google.pt/url? sa $=\mathrm{t} \& \mathrm{rct}=\mathrm{j} \& \mathrm{q}=\& \mathrm{esrc}=\mathrm{s} \&$ source $=$ web $\& \mathrm{~cd}=8 \& \mathrm{cad}=\mathrm{rja} \& u a c t=8$ \&ved=0ahUKEwiZp ik5vYAhUCkRQKHRIMDIYQFghaMAc\&url=http $\% 3 \mathrm{~A} \% 2 \mathrm{~F} \% 2 \mathrm{Fbisa} \cdot \mathrm{ac} . \mathrm{uk} \% 2 \mathrm{2Findex.php} \% 3$ Foption\%3Dcom bisa\%26task\%3Ddownload paper\%26no html\%3D1\%26passed paper id\%3D137\&usg=AOvVaw3Q89cwRvtULwLHLAlLrAMu>. Acesso em: 22 jan. 2018.

Bouët, A. (1998). Le protectionnisme. Analyse économique. Paris: Lebrairie Vuibert.

Brasil. (1994). Ministério da Economia, Indústria, Comércio Exterior e Serviços. Acordos da OMC: Acordo sobre a Implementação do Artigo VI do Acordo Geral Sobre Tarifas e Comércio 1994. Disponível em: $<\underline{\text { http://www.mdic.gov.br/comercio-exterior/negociacoes- }}$ internacionais/1885-omc-acordos-da-omc $>$. Acesso em: 22 mar. 2018.

British Institute of International and Comparative Law. (2002). Opinion of Advocate General Mischo. Disponível em: $<$ https://www.biicl.org/files/1822_c-164-99.pdf $>$. Acesso em: 21 fev. 2017.

Bunescu, L. M. (2011). The allegation of social dumping: a case study on Romania. Centre international de formation européenne, Institut Européen des Hautes Etudes Internationales. Disponível em: $<$ https://www.ie-ei.eu/IEEI/Ressources/file/memoires/2011/LBunescu.pdf>. Acesso em: 05 dez. 2018.

Casagrande, L. P. \& Antunes, T. C. M. O dumping social no âmbito internacional e a adoção do seu conceito no direito interno. In: Dutra, L. P. B. (2016). Dumping social no direito do trabalho e no direito econômico. Curitiba: Juruá. 
Cervantes, M. Don Quijote I (Spanish Edition) (Kindle Locations 1018-1026). Kindle Edition.

Comissão Europeia. (2017). O Estado da União. Disponível em:

$<$ https://ec.europa.eu/commission/sites/beta-political/files/state-union-2017-

brochure pt.pdf $>$. Acesso em: 22 nov. 2018.

Cordovil, L. A. G. (2009). O interesse público no antidumping. Tese (Doutoramento em Direito Econômico e Financeiro) - Universidade de São Paulo, São Paulo, p. 12.

Disponível em: $<$ http://www.teses.usp.br/teses/disponiveis/2/2133/tde-20102011131305/pt-br.php>. Acesso em: 27 abr. 2018.

Cremers, J. EU economic freedoms and social dumping. In: Bernaciak, M. (2015). Market Expansion and Social Dumping in Europe. London: Routledge.

Cretella Neto, J. (2012). Curso de direito internacional econômico. São Paulo: Saraiva. Cunha, L. P. (1997). Relações Económicas Externas. Coimbra: Almedina.

. (2001). Standards Sociais e Ambientais no Comércio Internacional. In:

Boletim de Ciências Económicas da Faculdade de Direito da Universidade de Coimbra, vol. XLIV, Coimbra.

. (2002). A Integração Regional e o Sistema Comercial Multilateral face à Globalização: convergência ou rivalidade?. In: Revista Brasileira de Direito Comparado, n. 22, Rio de Janeiro.

. (2008). O Sistema Comercial internacional e os espaços de integração regional. Coimbra: Coimbra Editora.

. (2014). O fracasso do Doha Round e a questão do desenvolvimento. In:

Boletim de Ciências Económicas da Faculdade de Direito da Universidade de Coimbra, vol. LVII, Tomo I, Coimbra.

Culbertson, A. (2017). Europe On The Edge: Macron to spark EU rupture as he cracks down on cheap eastern workers. Express. [on-line]. Disponível em:

$<$ https://www.express.co.uk/news/world/838272/Emmanuel-Macron-EU-easternEuropean-workers-labour-French-labour-laws-Poland-Hungary $>$. Acesso em: 22 nov. 2018. 
Duhigg, C. \& Barboza, D. (2012). In China, Human Costs Are Built Into an iPad. New York Times. [on-line]. Disponível em:

$<$ https://www.nytimes.com/2012/01/26/business/ieconomy-apples-ipad-and-the-humancosts-for-workers-in-china.html? $\mathrm{ref}=$ global-home\&pagewanted=all $>$. Acesso em: 23 jul. 2018 .

Dutra, L. P. B. (2016). Dumping social no direito do trabalho e no direito econômico. Curitiba: Juruá.

Esping-Andersen, G. (1998). The three worlds of welfare states capilaism. New Jersey: Princenton Press.

European Comission. (2016). Revisão relativa ao destacamento de trabalhadores perguntas frequentes. Estrasburgo, 8 de março de 2016. Disponível em:

$<$ http://europa.eu/rapid/press-release_MEMO-16-467_pt.htm>. Acesso em: 17 jan. 2018.

European Parliament. (2017). Understanding social dumping in the European Union. Disponível em:

$<$ http://www.europarl.europa.eu/RegData/etudes/BRIE/2017/599353/EPRS_BRI(2017)599 353_EN.pdf>. Acesso em: 04 mai. 2019.

European Foundation for the Improvement of Living and Working Conditions. Eurofound. (2016). Social dumping. Disponível em:

$<$ https://www.eurofound.europa.eu/observatories/eurwork/industrial-relationsdictionary/social-dumping $>$. Acesso em: 04 mai. 2019.

European Union Law. (1997). Directiva 96/71/CE do Parlamento Europeu e do Conselho de 16 de Dezembro de 1996 relativa ao destacamento de trabalhadores no âmbito de uma prestação de serviços. Jornal Oficial nº L 018 de 21/01/1997, pp. 0001-0006. Disponível em: $<\underline{\text { https: } / / \text { eur- }}$ lex.europa.eu/LexUriServ/LexUriServ.do?uri=CELEX:31996L0071:PT:HTML>. Acesso em: 30 nov. 2018.

. (2006). Acórdão do Tribunal de Justiça (Primeira Secção). Processo $n .{ }^{\circ} C$ 244/04. Disponível em: $<$ http://eur-lex.europa.eu/legalcontent/PT/TXT/?uri=CELEX:62004CJ0244> . Acesso em: 21 fev. 2017. 
European Trade Union Confederation. Free movement yes! Social dumping no! Disponível em:

$<$ https://www.etuc.org/sites/default/files/publication/files/flyer_social dumping_en_06.pdf >. Acesso em: 22 nov. 2018.

Faria, J. E. (2010). Sociologia Jurídica: direito e conjuntura. 2. ed. São Paulo: Saraiva. [versão eletrónica].

Ferreira, C. A. (2009). Os Impactos da Prática de Dumping no Comércio Internacional. In: Revista Eletrônica da Faculdade de Direito da PUC - SP, n. 2. Disponível em: $<$ https://revistas.pucsp.br/index.php/red/article/view/1717>. Acesso em: 02 mar. 2018.

Gava, R. (2008). Ricos \& Mendazes: O Dilema das Cláusulas Sociais nas Relações Multilaterais de Comércio Internacional. Coimbra: Almedina.

Geraldello, C. S. (2015a). Antidumping na OMC. In: Medidas antidumping e política doméstica: o caso da citricultura estadunidense [on-line]. São Paulo: Cultura Acadêmica. Disponível em:

$<\underline{\text { https://repositorio.unesp.br/bitstream/handle/11449/138597/ISBN9788579836657.pdf?se }}$ quence $=1 \&$ isAllowed=y $>$. Acesso em: 23 abr. 2018.

. (2015b). As medidas antidumping na Organização Mundial do Comércio e os constrangimentos aos Estados Unidos. In: Boletim Meridiano 47, vol. 16, n. 151, pp. 1828. Disponível em:

$<$ https://www.researchgate.net/publication/293042487 As medidas antidumping na Org anizacao_Mundial do_Comercio_e os constrangimentos_aos_Estados_Unidos $>$. Acesso em: 29 abr. 2019.

Gomes, A. V. \& Bezerra, L. P. Questionamentos acerca da construção doutrinária e jusrisprudencial do dumping social: do Direito do Comércio Internacional ao Direito do Trabalho Brasileiro. In: Dutra, L. P. B. (2016). Dumping social no direito do trabalho e no direito econômico. Curitiba: Juruá.

Greer, I. \& Doellgast, V. (2017). Marketization, inequality, and institutional change: Toward a new framework for comparative employment relations. Journal of Industrial Relations, 59(2), 192-208. Disponível em:

$<$ https://www.researchgate.net/profile/Ian_Greer3/publication/313486874_Marketization_i nequality and institutional_change Toward a new framework for_comparative employ ment relations/links/59fc66b40f7e9b9968bd6e0c/Marketization-inequality-andinstitutional-change-Toward-a-new-framework-for-comparative-employmentrelations.pdf >. Acesso em: 28 jan. 2019. 
Greer, I. \& Hauptmeier, M. (2014). Social dumping as marketization: Management whipsawing in Europe's auto industry. Cornell University, ILR School. [on-line]. Disponível em: $<$ https://digitalcommons.ilr.cornell.edu/articles/969/>. Acesso em: 04 fev. 2019.

. Marketization and social dumping: Management whipsawing in Europe's auto industry. In: Bernaciak, M. (2015). Market Expansion and Social Dumping in Europe. London: Routledge.

Hon Hai/Foxconn Technology Group. [on-line]. Disponível em:

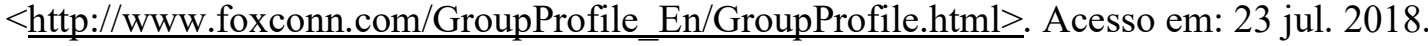

International Labor Organization. (1996-2017). Normlex: Information System on International Labour Standards. [on-line]. Disponível em: $<$ https://www.ilo.org/dyn/normlex/en/f?p=NORMLEXPUB:1:0::NO $>$. Acesso em: 26 jul. 2018.

. (1996-2017). Ratifications by country. [on-line]. Disponível em:

$<$ https://www.ilo.org/dyn/normlex/en/f?p=1000:11001:::NO:::\#F>. Acesso em: 26 jul. 2018.

. (1996-2017). The Rana Plaza Accident and its aftermath. [on-line]. $<$ http://www.ilo.org/global/topics/geip/WCMS_614394/lang--en/index.htm>. Acesso em: 22 jul. 2018.

. (1998). Declaração da OIT sobre os Princípios e Direitos Fundamentais no trabalho. [on-line]. Disponível em: $<$ https://www.ilo.org/public/english/standards/declaration/declaration_portuguese.pdf $>$. Acesso em: 02 mai. 2019.

. (2004). World Commission on the Social Dimension of Globalization. [online]. Disponível em: $<$ https://www.ilo.org/public/english/wcsdg/index1.htm>. Acesso em: 18 fev. 2019.

Johnson, J. (2011). 1 Million Workers. 90 Million iPhones. 17 Suicides. Who's to Blame? Wired. [on-line]. Disponível em: $<\underline{\text { https://www.wired.com/2011/02/ff joelinchina/all/1/>. }}$. Acesso em: 23 jul. 2018. 
Jorge, D. M. (2015). Direito antidumping \& comércio internacional: medidas antidumping para o desenvolvimento econômico e proteção da indústria doméstica. Curitiba: Juruá.

Koopmans, R. (2004). Movements and Media: Selection Processes and Evolutionary Dynamics in the Public Sphere. In: Theory and Society, 33:367-391. Disponível em: $<$ https://pdfs.semanticscholar.org/2fb3/ef9bba6688664170f17f3c85c05910292bf8.pdf $>$. Acesso em: 22 nov. 2018.

Laurino, S. F. L. (2013). Destacamento de Trabalhadores: Dumping social e os desafios à afirmação do espaço social europeu. São Paulo: LTr.

Lima, R. A.; Magalhães, A. A. A. \& Sousa, S. P. (2017). As influências da teoria da "workable competiton" como forma mais eficaz de prática da concorrência na legislação brasileira. In: Revista da Defesa da Concorrência, vol. 5, n. 2. Brasília: CADE, pp. 230231. Disponível em:

$<$ http://revista.cade.gov.br/index.php/revistadedefesadaconcorrencia/article/view/342/176> . Acesso em: 09 mar. 2018.

Linos, C. [s.n.]. Phobia of polish plumbers: evaluating the prevalence and effects of social dumping in sweden in the context of european integration. Paper apresentado no âmbito da disciplina Economics of European Integrations na Harvard University, p. 04. Disponível em:

$<$ http://elnd.gr/index.php/gr/\%CE $\%$ B5 $\% \mathrm{CF} \% 81 \% \mathrm{CE} \% \mathrm{~B} 5 \% \mathrm{CF} \% 85 \% \mathrm{CE} \% \mathrm{BD} \% \mathrm{CE} \% \mathrm{~B} 7$ $\% \mathrm{CF} \% 84 \% \mathrm{CE} \% \mathrm{~B} \% \% \mathrm{CE} \% \mathrm{BA} \% \mathrm{CE} \% \mathrm{AE}-$ \%CE $\%$ B $4 \% \mathrm{CF} \% 81 \% \mathrm{CE} \% \mathrm{~B} 1 \% \mathrm{CF} \% 83 \% \mathrm{CF} \% 84 \% \mathrm{CE} \% \mathrm{~B} 7 \% \mathrm{CF} \% 81 \% \mathrm{CE} \% \mathrm{~B} 9 \% \mathrm{CF} \% 8 \mathrm{C}$ \%CF $\% 84 \% \mathrm{CE} \% \mathrm{~B} 7 \% \mathrm{CF} \% 84 \% \mathrm{CE} \% \mathrm{~B} 1 / \% \mathrm{CE} \% \mathrm{~B} 6 \% \mathrm{CE} \% \mathrm{~B} 7 \% \mathrm{CF} \% 84 \% \mathrm{CE} \% \mathrm{AE} \% \mathrm{CE} \% \mathrm{~B}$ $\mathrm{C} \% \mathrm{CE} \% \mathrm{~B} 1 \% \mathrm{CF} \% 84 \% \mathrm{CE} \% \mathrm{~B} 1-$ \%CE $\%$ B $5 \% \mathrm{CF} \% 85 \% \mathrm{CF} \% 81 \% \mathrm{CF} \% 89 \% \mathrm{CF} \% 80 \% \mathrm{CE} \% \mathrm{~B} 1 \% \mathrm{CF} \% 8 \mathrm{~A} \% \mathrm{CE} \% \mathrm{BA} \% \mathrm{CE} \% \mathrm{AE}$ $\% \mathrm{CF} \% 82-$

$\% \mathrm{CE} \% \mathrm{AD} \% \mathrm{CE} \% \mathrm{BD} \% \mathrm{CF} \% 89 \% \mathrm{CF} \% 83 \% \mathrm{CE} \% \mathrm{~B} 7 \% \mathrm{CF} \% 82 /$ item $/$ download $/ 3$ f $80349 \mathrm{eb} 0$ b5c414ee67e400ae2eb89ee>. Acesso em: 16 jan. 2019.

Lough, R. \& Kelly, L. (2017). Emmanuel Macron wants to re-shape Europe. Business Insider. [on-line]. Disponível em: $<\underline{\text { https://www.businessinsider.com/r-frances-macron- }}$ seeking-to-re-shape-europe-heads-east-2017-8>. Acesso em: 22 nov. 2018.

Malloy, R. P. (2017). Law, Market, and Marketization. University of Bologna Law Review (issue 2) 166. Disponível em: <https://ssrn.com/abstract=3019495>. Acesso em: 28 jan. 2019. 
Meireles, G. F. (2016). Trabalho, comércio e dignidade no Direito Internacional contemporâneo. Curitiba: Juruá.

Moreira, V. (2014). Trabalho digno para todos: A "cláusula laboral” no comércio internacional na União Europeia. Coimbra: Coimbra Editora.

Nascimento, A. P. \& Anacoreta, J. P. (2007). Destacamento de trabalhadores. In: Foro de Actualidad, vol. 18, p. 120. Disponível em:

$<$ http://www.uria.com/documentos/publicaciones/1812/documento/articuloUM.pdf?id=317 5 >. Acesso em: 31 jan. 2019.

Negrini, M. C. (2013). O direito ao desenvolvimento na esfera das Nações Unidas. Disponível em: $<$ https://jus.com.br/artigos/23957/o-direito-ao-desenvolvimento-na-esferadas-nacoes-unidas $>$. Acesso em: 25 jul. 2018.

Nunes, A. J. A. (2012). A última máscara do estado capitalista. In: Estudos em Homenagem ao Prof. Doutor Aníbal Almeida. Colecção Stvdia Ivridica, 107, Ad Honorem - 7, Boletim da Faculdade de Direito de Coimbra, Coimbra: Coimbra Editora, 761-791. . (2013). Noção e objecto da Economia Política. Coimbra: Almedina, 2013.

Nunes, M. F. (2015). The impact of negative social/environmental events on the market value of supply chain partners. Dissertação (Mestrado). Fundação Getúlio Vargas Escola de Administração de Empresas de São Paulo, São Paulo, 184p. Disponível em: $<$ https://bibliotecadigital.fgv.br/dspace/bitstream/handle/10438/15045/Masters\%20Disserta tion.MFN-2016.Jan\%20-\%20v.final.protocolo2.pdf>. Acesso em: 23 jul. 2018.

Nusdeo, F. (2015). Curso de economia: introdução ao direito econômico. 9. ed. São Paulo: Editora Revista dos Tribunais.

Nwauche, E. S. \& Nwobike, J. C. (2005). Implementing the right to development. Sur, Rev. int. direitos human., São Paulo, v. 2, n. 2, pp. 96-117. Disponível em: $<\underline{\text { http: } / / \text { www.scielo.br/scielo.php?script }=\text { sci arttext\&pid }=\text { S1806- }}$ 64452005000100005\&lng=en\&nrm=iso $>$. Acesso em: 25 jul. 2018.

Office of the United States Trade Representative. (2018). USMCA Text. [on-line]. Disponível em $<$ https://ustr.gov/sites/default/files/files/agreements/FTA/USMCA/Text/23 Labor.pdf $>$. Acesso em: 10 jan. 2019. 
Parlamento Europeu. (1957). Tratado de Roma (CEE). Disponível em:

$<\underline{\text { http://www.europarl.europa.eu/about-parliament/pt/in-the-past/the-parliament-and-the- }}$ treaties/treaty-of-rome> . Acesso em: 17 jan. 2018.

. (2016). Relatório sobre dumping social na União Europeia. Comissão do Emprego e dos Assuntos Sociais, Relator: Guillaume Balas. Disponível em: $<$ http://www.europarl.europa.eu/sides/getDoc.do?pubRef=-//EP//TEXT+REPORT+A82016-0255+0+DOC+XML+V0//PT>. Acesso em: 17 jan. 2018. . (2017). Understanding social dumping in the European Union. Disponível em: $<$ http://www.europarl.europa.eu/thinktank/en/document.html?reference=EPRS BRI(2017) 599353>. Acesso em: 30 nov. 2018.

Peixinho, M. M. \& Ferraro, S. A. (2003). Direito ao desenvolvimento como direito fundamental. Disponível em:

$<$ http://www.publicadireito.com.br/conpedi/manaus/arquivos/anais/bh/manoel_messias_pe ixinho.pdf>. Acesso em: 20 mai. 2018.

Portela, P. H. G. (2016). Direito Internacional Público e Privado: Incluindo Noções de Direitos Humanos e de Direito Comunitário. 8. ed. Salvador: JusPodivm.

Porto, M. C. L. (1986). Protecionismo. In: Polis: Enciclopédia Verbo da Sociedade e do Estado, vol. 04. Lisboa: Verbo. . (2017). Teoria da integração e políticas da União Europeia: Face aos

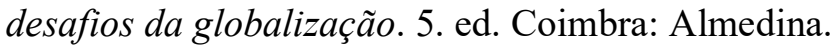

ProPublica. (2012). By the Numbers: Life and Death at Foxconn. [on-line]. Disponível em: $<$ https://www.propublica.org/article/by-the-numbers-life-and-death-at-foxconn $>$. Acesso em: 23 jul. 2018.

Quadros, F. (2015). Direito da União Européia: Direito Constitucional e Administrativo da União Européia. 3. ed. Coimbra: Almedina.

Ricardo, D. (2004). On the Principles of Political Economy and Taxation (Kindle Locations 1223-1229). Library of Alexandria. Kindle Edition. 
Sapir, A. (2015). Single market and social protection: friends or foes? Université Libre de Bruxelles. Presentation prepared for an Informal Meeting of Labor Ministers (revised). Hosted by Sweden's Minister for Employment. Stockholm, 11 September 2015. Disponível em: $<$ http://bruegel.org/wp-content/uploads/2016/03/Sapir-2015Stockholm.pdf>. Acesso em: 26 nov. 2016.

Silva, A. L. G. (2010). Concorrência sob condições oligopolísticas: Contribuições das análises centradas no grau de atomização/concentração dos mercados. Campinas, SP: Unicamp. (Coleção Teses).

Stiglitz, J. E.; Charlton, A. (2009). Comércio Justo para Todos: como o comércio pode promover o desenvolvimento. Tradução: Jacqueline Sandra. Lisboa: Texto Editores.

The Economist. (2011). Two-speed Europe, or two Europes? [on-line]. Disponível em: $<$ https://www.economist.com/charlemagne/2011/11/10/two-speed-europe-or-twoeuropes $>$. Acesso em: 22 nov. 2018.

The Guardian. (2013). Bangladesh textile factory fire leaves more than 100 dead. [on-line]. Disponível em: $<$ https://www.theguardian.com/world/2012/nov/25/bangladesh-textilefactory-fire $>$. Acesso em: 22 jul. 2018.

. (2014). UK gains £20bn from European migrants, UCL economists reveal. [on-line]. Disponível em: <https://www.theguardian.com/uk-news/2014/nov/05/eumigrants-uk-gains-20bn-ucl-study>. Acesso em: 04 fev. 2019.

. (2016). Trump's economic policies: protectionism, low taxes and coal mines. [on-line]. Disponível em: $<$ https://www.theguardian.com/us-news/2016/nov/09/trumpseconomic-policies-protectionism-low-taxes-and-coal-mines $>$. Acesso em: 21 nov. 2018.

The World Bank. (2001). Globalization, Growth and Poverty: building an inclusive world economy. [on-line]. Disponível em:

$<$ http://documents.worldbank.org/curated/en/954071468778196576/Globalization-growthand-poverty-building-an-inclusive-world-economy $>$. Acesso em: 02 mar. 2018.

Thorstensen, V. (1998). A OMC - Organização Mundial do Comércio e as negociações sobre investimentos e concorrência. Rev. bras. polit. int., Brasília, v. 41, n. 1, pp. 57-89.

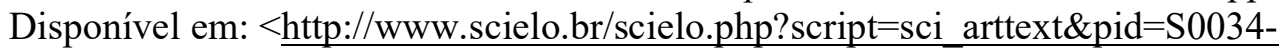
73291998000100004\&lng=en\&nrm=iso $>$. Acesso em: 18 fev. 2019. 
Trappmann, V. Social dumping with no divide: evidence from multinational companies in Europe. In: Bernaciak, M. (2015). Market Expansion and Social Dumping in Europe. London: Routledge.

Tribunal de Justiça da União Europeia (1990a). Acórdão do Tribunal (Sexta secção). Processo n. ${ }^{\circ} \mathrm{C}-113 / 89$. Disponível em:

$<$ http://curia.europa.eu/juris/showPdf.jsf;jsessionid=9ea7d0f130deb88764f09ce84d9cb4d8 c5b4bc437c2a.e34KaxiLc3eQc40LaxqMbN4Pb300e0?text $=\&$ docid $=96686 \&$ pageIndex $=0$ \&doclang $=$ PT\&mode $=1$ st\&dir $=\&$ occ $=$ first $\&$ part $=1 \&$ cid $=403378>$. Acesso em: 21 fev. 2018.

. (1990b). Conclusões do Advogado-Geral Walter Van Gerven: apresentadas em 7 de março de 1990. Disponível em:

$<$ http://curia.europa.eu/juris/showPdf.jsf;jsessionid=9ea7d0f130deb88764f09ce84d9cb4d8 c5b4bc437c2a.e34KaxiLc3eQc40LaxqMbN4Pb30Oe0?text $=$ \&docid=96648\&pageIndex $=0$

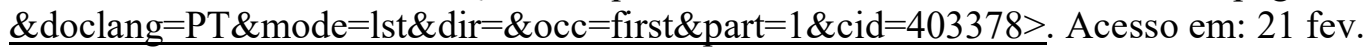
2018.

. (2007). Acórdão do Tribunal de Justiça (Grande Secção). Disponível em: $<$ http://curia.europa.eu/juris/liste.jsf?language $=\mathrm{pt \& num}=\mathrm{C}-341 / 05>$. Acesso em: $22 \mathrm{fev}$. 2018.

. (2014). Conclusões do Advogado-Geral Nils Wahl: apresentadas em 18 de setembro de 2014. Disponível em:

$<$ http://curia.europa.eu/juris/document/document.jsf?text $=\&$ docid $=157856 \&$ pageIndex $=0$

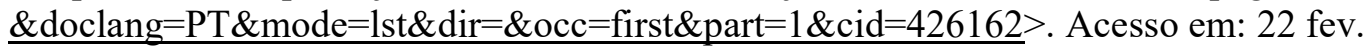
2018.

. (2015). Acórdão do Tribunal de Justiça (Primeira Secção). Processo n. ${ }^{\circ} C^{-}$ 396/13. Disponível em: $<\underline{\text { http://curia.europa.eu/juris/document/document.jsf?text }=\& \text { docid }=162247 \& \text { pageIndex }=0}$

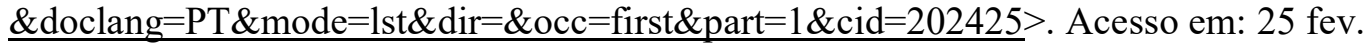
2018.

Universidade de Fortaleza. (2018). The United States-Mexico-Canada Agreement (USMCA): A summary. Unifor Research Department. Disponível em: $<$ https://www.unifor.org/sites/default/files/attachments/usmca_uniforanalysis_oct2018 eng 0.pdf>. Acesso em: 10 jan. 2019. 
USA Today. (2013). Toll in Bangladesh building collapse climbs to 275. [on-line]. Disponível em: $<$ https://eu.usatoday.com/story/news/world/2013/04/24/bangladeshbuilding-collapse/2108727/>. Acesso em: 22 jul. 2018.

Varela, C. A. (2006). Chutando a Escada: a estratégia do desenvolvimento em perspectiva histórica. Rev. Econ. Polit. [on-line], vol. 26, n. 4, pp. 627-628. Disponível em: $<$ http://www.scielo.br/scielo.php?script $=$ sci arttext\&pid $=$ S010131572006000400010\&lng=pt\&tlng=pt>. Acesso em: 22 abr. 2018.

Vey, J. B.; Kar-Grupat, S. \& Balmforth, R. (2017). France's Macron, on Eastern Europe trip, to raise issue of cheap labor. Reuters. [on-line]. Disponível em: $<$ https://www.reuters.com/article/us-france-easteurope-macron-idUSKBN1AN1G9>. Acesso em: 21 nov. 2018.

Viner, J. (1922). Dumping as a Method of Competition in International. In: The University Journal of Business. Chicago, EUA, vol. I, n. 1. Disponível em: $<$ http://www.jstor.org/stable/2354748? seq $=2 \#$ page scan tab_contents $>$. Acesso em: 13 mar. 2018.

. (1924). Dumping: A Problem in International Trade. In: Chicago University Press. Chicago, vol. 32, n. 4. Disponível em:

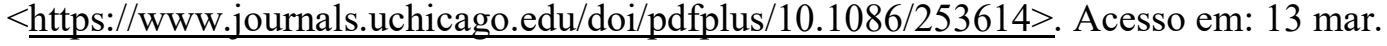
2018.

World Trade Organization. (1997). Singapore Ministerial Declaration. [on-line]. Disponível em: $<$ https://www.wto.org/english/thewto_e/minist_e/min96_e/wtodec_e.htm>. Acesso em: 27 jul. 2018.

. (2001). Doha WTO Ministerial Declaration [on-line]. Disponível em: $<$ https://www.wto.org/english/thewto_e/minist e/min01_e/mindecl_e.htm $>$. Acesso em: 27 jul. 2018.

. Disponível em: $<$ https://www.wto.org $>$. Acesso em: 20 abr. 2018.

. The General Agreement on Tariffs and Trade (GATT 1947). Disponível em: $<$ https://www.wto.org/english/docs_e/legal_e/gatt47_01_e.htm\#art6>. Acesso em: $01 \mathrm{abr}$. 2019. 